\title{
HYDROLOGY AND EFFECTS OF MINING IN THE QUITCHUPAH AND PINES COAL-LEASE TRACTS, CENTRAL UTAH
}

\section{U.S. GEOLOGICAL SURVEY}

Water-Resources Investigations Report 90-4084
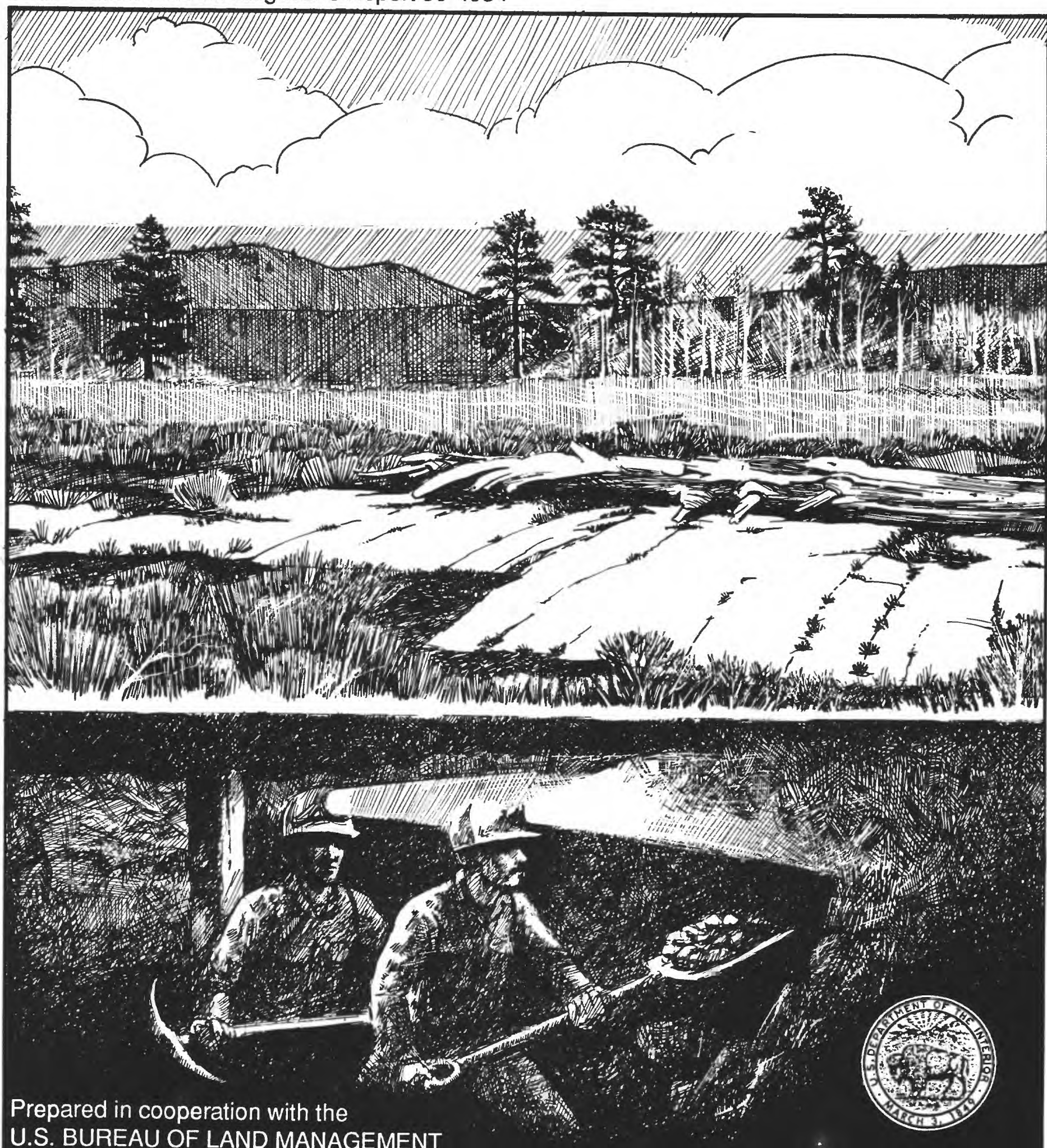
COVER: Sketch by Charles E. Turner depicting fracturing in the Castlegate Sandstone and the potential for coal mining in the Quitchupah and Pines coal-lease tracts. 
HYDROLOGY AND POTENIIAL EFFECTS OF MINING

IN THE QUTTCHUPAH AND PINES

COAL-LEASE TRACTS, CENIRAL UTAH

By S.A. Thiros and G.E. Cordy

U.S. GEOLOGICAL SURVEY

Water-Resources Investigations Report 90-4084

Prepared in cooperation with the

U.S. BUREAU OF LAND MANAGEMENT

Salt Lake City, Utah 
U.S. DEPARTMENT OF THE INIERIOR

MANUEU, LUUAN, JR., Secretary

U.S. GEOLOGICAL SURVEY

Dallas L. Peck, Di rector

For additional information write to:

District Chief

U.S. Geological Survey, WRD Roan 1016 Administration Building 1745 West 1700 South

Salt Lake City, Utah 84104
Copies of this report can be purchased from:

U.S. Geological Survey

Books and open-File Reports Section

Federal Center, Bldg. 810

Box 25425

Denver, Colorado 80225

ii 
Page

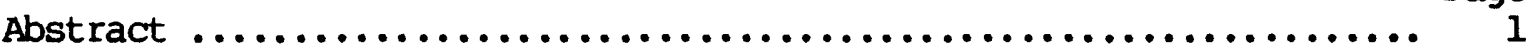

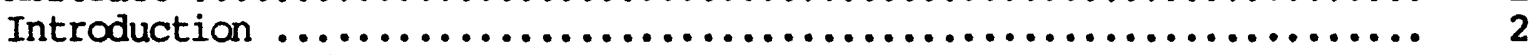

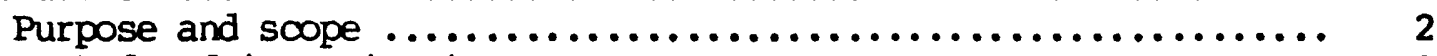

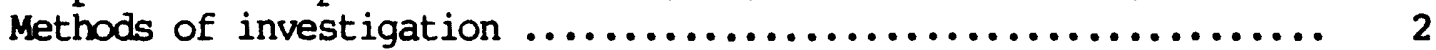

Ground-water site-numbering system ...................... 5

Acknowledgments .................................... 5

Physical setting ...................................

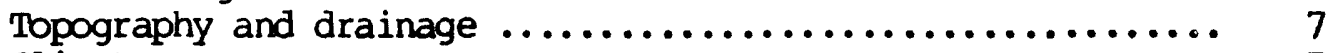

Climate ...................................... 7

Geology and structure ............................ 10

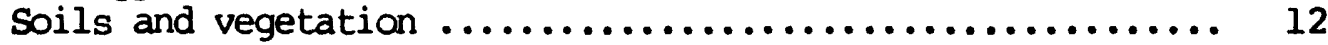

Land use ....................................... 12

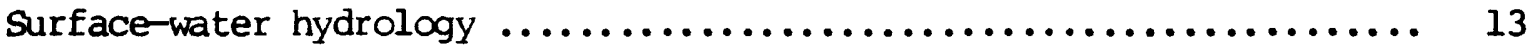

Discharge ......................................... 13

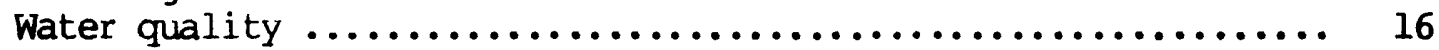

Erosion and estimated sediment yield ...................... 2l

Ground-water hydrology ..................................... 24

General occurrence, recharge, and discharge ................ 27

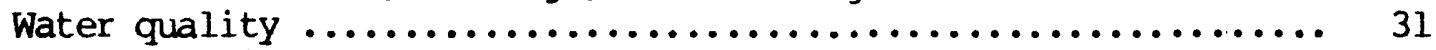

Flagstaff Limestone and the North Horn Formation ............. 31

Price River Formation and the Castlegate Sandstone ........... ... 36

Blackhawk Formation and the Star Point Sandstone ............. 40

Aquifer properties .............................. 41

Recharge ....................................... 41

Movement ................................... 41

Discharge ................................... 42

Water quality .................................. 42

Effects of mining in the Quitchupah and Pines coal-lease tracts area .50

Potential effects .................................... 50

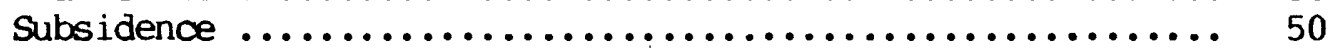

Ground-water occurrence and quality .................. 50

Surface-water flow and quality ...................... 51

Observed effects .................................... 51

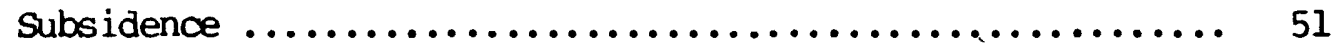

Ground-water occurrence and quality .................. 52

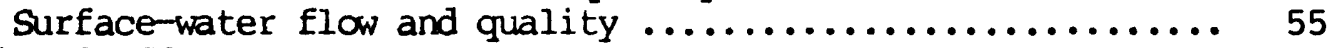

Predicted effects .................................. 58

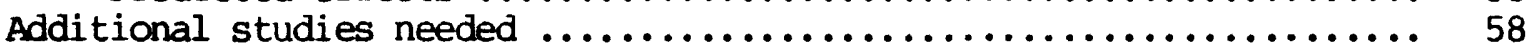

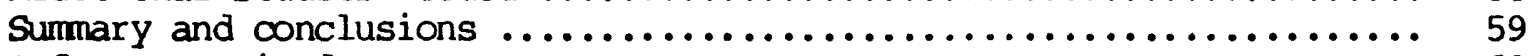

References cited ........................................60 


\section{IILUSTRATIONS \\ [Plate is in pocket]}

Plate 1. Map showing geology, water-quality diagrams, and location of hydrologic-data-collection sites in the Quitchupah and Pines study area, Utah

Figure 1. Map of Utah showing location of the Wasatch Plateau

Page coal field and the Quitchupah and Pines coal-lease

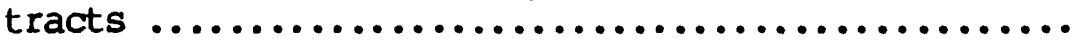

2. Map showing location of the Quitchupah and Pines coallease tracts, the tract containing the Southern Utah Fuel Company (SUFCo) mine, and the boundary

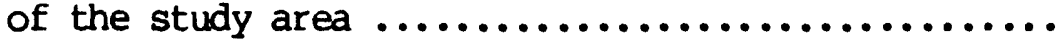

3. Diagram showing ground-water site-numbering system used in Utah .............................. 6

4. Photograph showing typical topography and vegetative cover of the Quitchupah and Pines study area ........

5. Photograph showing the predominant fracture pattern in a Castlegate Sandstone outcrop near North Fork

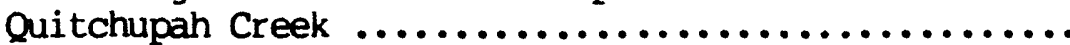

6. Graph showing average monthly temperature and precipitation, 1979-86, and annual precipitation,

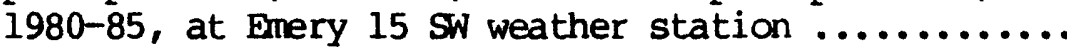
6

7. Photograph showing view (facing west) of some of the geologic formations exposed in the Quitchupah and Pines study area ............................

8-13. Graphs showing:

8. Annual mean discharge of Muddy Creek near Emery, Utah (USGS Station 09330500), 1950-86 .........

9. Monthly mean and annual mean discharge for water year 1986, and mean monthly and mean annual discharge for water years 1950-85 at the

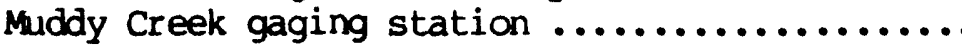

10. Relation between specific conductance and discharge at North Fork Quitchupah Creek (site

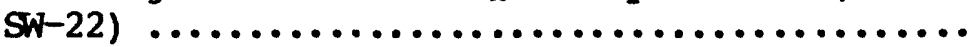

11. General relation of stream discharge to suspendedsediment load for streams draining the study

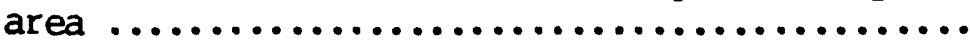

12. General relation of stream discharge to suspendedsediment concentration at the Quitchupah Creek

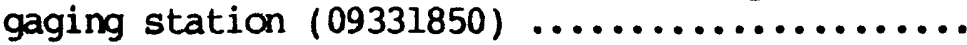

13. Gains and losses in flow in North Fork Quitchupah Creek on September 10 and 11, 1987 ..

14. Generalized stratigraphic column for the study area and representative water-quality diagrams for selected units ......................

15-18. Hydrographs showing:

15. June discharge at East Spring and cumulative departure of the peak water content at Blacks Fork snow course, 1976-87 .................. 
Figures 15-18. Hydrographs showing:--Continued

16. Discharge of springs (D-2l-4)36ddc-Sl and

(D-2l-5) 26bba-Sl, and mine outflow

(D-21-5) 26bcd, 1986-87 ................... 39

17. Discharge measured at East Spring,

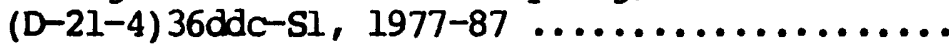

18. Water-level changes in selected SUFCo monitoring

wells completed in the upper Hiawatha coal seam

of the Blackhawk Formation ..................

19. Map showing extent of land subsidence in the

southwestern part of the study area in $1986 \ldots \ldots \ldots$. .

20. Photograph showing tension crack in alluvium

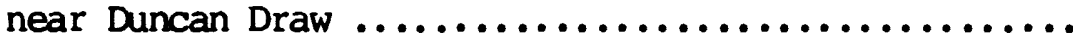

21. Photograph showing tension crack about 2.5 inches wide in Castlegate Sandstone near Duncan Draw ...........

22. Map showing subsidence contours, tension cracks, and natural fracture pattern encountered in

subsidence area 1 of the SUFCo mine, $1986 \ldots . . \ldots \ldots$.....

23. Hydrograph showing changes in the water level in monitoring well $(\mathrm{D}-22-5) 5 \mathrm{c} \ldots \ldots \ldots \ldots \ldots \ldots \ldots \ldots \ldots$

TABLES

Table 1. Regression equations used to compute peak and average streamflow from ungaged tributaries of the Quitchupah

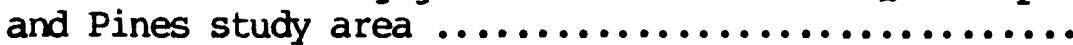

2. Calculated average and 10-year peak flows for perennial streams in the Quitchupah and Pines study area ......

Page ischarge, specific conductance, temperature, and concentration of suspended sediment in selected streans . .................................

4. Chemical analyses of water from selected surface-water sites ................................... 22

5. Discharge, temperature, and specific conductance of water from selected springs and mines ............ 28

6. Chemical analyses of water from selected ground-water sites .................................. 32

7. Summary of solubility indices for ground water from selected springs and mine inflow sites ........... 35

8. Geologic and hydrologic data from selected coal-test holes and wells ........................... 


\section{CONVERSION FACTORS}

For readers who prefer to use metric units, conversion factors for terms used in this report are listed below:

Multiply Inch-pound units

inch (in.)
foot ( $\mathrm{ft}$ )
mile (mi)

acre

square mile $\left(\mathrm{mi}^{2}\right)$

acre-foot (acre-ft)

cubic foot per second $\left(\mathrm{ft}^{3} / \mathrm{s}\right)$

gallon per minute (gal/min)

acre-foot per square mile

(acre-ft/mi ${ }^{2}$ )

tons per day (tons/d)

Transmissivity

foot squared per day ( $\mathrm{ft}^{2} / \mathrm{d}$ )

foot per mile (ft/mi)
0.9072

by

To obtain metric unit

\section{Length}

2.540

0.3048

1.609

centimeter

meter

kilometer

Area

0.4047

2.590

square hectometer

square kilometer

Volume

0.001233

cubic hectometer

\section{Flow}

0.02832

0.06309

cubic meter per second

liter per second

\section{Yield}

$$
0.000476
$$

cubic hectaneter per square kilometer

metric ton per day

0.0929

meter squared per day

Gradient

0.1894

meter per kilometer

Water and air temperature are given in degrees Celsius $\left({ }^{\circ} \mathrm{C}\right)$, which can be converted to degrees Fahrenheit $\left({ }^{\circ} \mathrm{F}\right)$ by the following equation:

$$
{ }^{\circ} \mathrm{F}=1.8\left({ }^{\circ} \mathrm{C}\right)+32 \text {. }
$$

Concentrations of chemical constituents are given in milligrams per liter $(\mathrm{mg} / \mathrm{L})$ or micrograms per liter $(\mu \mathrm{g} / \mathrm{L})$. Milligrams per liter is a unit expressing the concentration of a chemical constituent as the weight (milligrams) of solute per unit volume (liter of water). One thousand micrograms per liter is equivalent to 1 milligram per liter. The concentration of chemical constituents, in parts per million, is about the same as the concentration in milligrams per liter for concentrations less than $7,000 \mathrm{mg} / \mathrm{L}$. 
Concentration of radioisotopes is expressed in picocuries per liter $(\mathrm{pCi} / \mathrm{L})$, which is the amount of radioactive decay producing 2.2 disintegrations per second in a unit volume (liter) of water.

Specific conductance is reported in microsiemens per centimeter at $25{ }^{\circ} \mathrm{C}$ $(\mu \mathrm{S} / \mathrm{cm})$. Alkalinity (as calcium carbonate) consists primarily of bicarbonate with only small amounts of carbonate; thus bicarbonate will be used in place of alkalinity in this report.

National Geodetic Vertical Datum of 1929 (NGVD of 1929)-A geodetic datum derived from a general adjustment of the first-order level nets of both the United States and Canada, formerly called "Sea Level Datum of 1929." 
HYDROLOGY AND POTENTIAL EFFECTS OF MINING IN THE QUITCHIPAH AND PINES

COAL-LEASE TRACTS, CENIRAL UTAH

By S.A. Thiros and G.E. Cordy

ABSTRACT

Hydrologic data were collected for the proposed Quitchupah and Pines coal-lease tracts in Sevier and Emery Counties, Utah, in order to describe the hydrology and potential effects of mining on the hydrologic system. The Quitchupah and Pines coal-lease tracts are near the Southern Utah Fuel Campany coal mine in an area of the central Wasatch Plateau that is characterized by a relatively flat plateau deeply dissected by steep-sided canyons.

Surface water in the Quitchupah and Pines study area drains to two perennial streams, Muddy Creek to the north and Quitchupah Creek to the south. Peak streamflow is usually in May and June in response to snowmelt runoff; however, thunderstorms can cause short-term high flows in late sumer and fall. The specific conductance of surface water in and near the study area measured during the 1987 water year ranged from $440 \mu \mathrm{S} / \mathrm{cm}$ to $860 \mu \mathrm{S} / \mathrm{cm}$. Suspended-sediment concentrations ranged from 17 to $10,900 \mathrm{mg} / \mathrm{L}$ in the quitchupah Creek drainage and 34 to $312 \mathrm{mg} / \mathrm{L}$ in the Muddy Creek drainage.

Stable-isotope studies indicate that recharge to aquifers in the study area is by seepage of snowmelt into rock outcrops. Discharge from the aquifers is at springs, seeps, mines, and zones of seepage in streambeds. The chemical quality of ground water is related to the mineralogy of the formations with which the water has contact. Water from the upper part of the Castlegate Sandstone has the smallest concentration of dissolved solids, 61 $\mathrm{mg} / \mathrm{L}$, and water from the North Horn Formation has the largest concentration, $1,080 \mathrm{mg} / \mathrm{L}$.

Cbserved effects of underground coal mining at the nearby active mine are considered indicative of the changes that can be expected in the Quitchupah and Pines coal-lease tracts. Subsidence above the mined area could cause dewatering of the Blackhawk Formation and the Star Point Sandstone, changes in the natural drainage patterns, and alteration of both surface- and ground-water quality. Additional studies are needed to gain a better understanding of the hydrologic effects of underground mining in the quitchupah and Pines coal-lease tracts. 


\section{INIRODUCTION}

The Quitchupah and Pines coal-lease tracts in central Utah are being considered for future leasing. In order to provide information for the prediction and mitigation of the effects of coal mining on the water resources of the area, the U.S. Geological Survey, in cooperation with the Bureau of Land Management, U.S. Department of Interior, initiated a study of the hydrologic system. The study was conducted from June 1986 to september 1987.

The Quitchupah and Pines coal-lease tracts are in the Wasatch Plateau coal field of central Utah (fig. 1). Coal is currently being mined from the upper Hiawatha coal seam of the Cretaceous Blackhawk Formation in the Southern Utah Fuel Company (SUFCo) underground mine directly south of the Quitchupah cal-lease tract (fig. 2).

\section{Purpose and Scope}

The purpose of this report is to describe the hydrology and potential effects of mining on the hydrologic system in the Quitchupah and Pines coallease tracts. Because data for the two coal-lease tracts were sparse, it was necessary to use information from geologically comparable areas adjacent to the proposed lease tracts. Data from the SUFCo mine, south of the Quitchupah tract, were useful in determining the potential effects of mining.

Information compiled for this study included hydrologic, topographic, geologic, meteorologic, soil, and land-use data. From these data, sediment yield, aquifer characteristics, ground-water recharge, movement, and discharge, and the quality and quantity of streamflow and spring discharge were estimated to establish baseline values for the lease tracts.

\section{Methods of Investigation}

Ground-water and surface-water data were collected and analyzed in order to characterize the ground-water flow system in the quitchupah and Pines coallease tracts. Data collected during the course of the study included: (1) an inventory of springs in and adjacent to the coal-lease tracts, (2) discharge of perennial streams, (3) sediment samples from perennial streams, and (4) water-quality samples from springs, streams, and mines.

Coastal States Energy Company provided ground-water, surface-water, and drillhole data from the Southern Utah Fuel Company (SUFCo) mine and the surrounding areas. Emphasis was placed on evaluating the effects of the SUFCo mine on the area in order to predict future effects of mining on the quitchupah and Pines coal-lease tracts.

Peak and average streamflows from ungaged drainages were estimated with regression equations developed for Utah streams (Christensen and others, 1986; Thamas and Lindskov, 1983). Estimates of sediment yield from the coal-lease tracts were calculated using the Pacific Southwest Inter-Agency Comittee (PSIAC) method as modified by Frickel and others (1975, p. 17). 


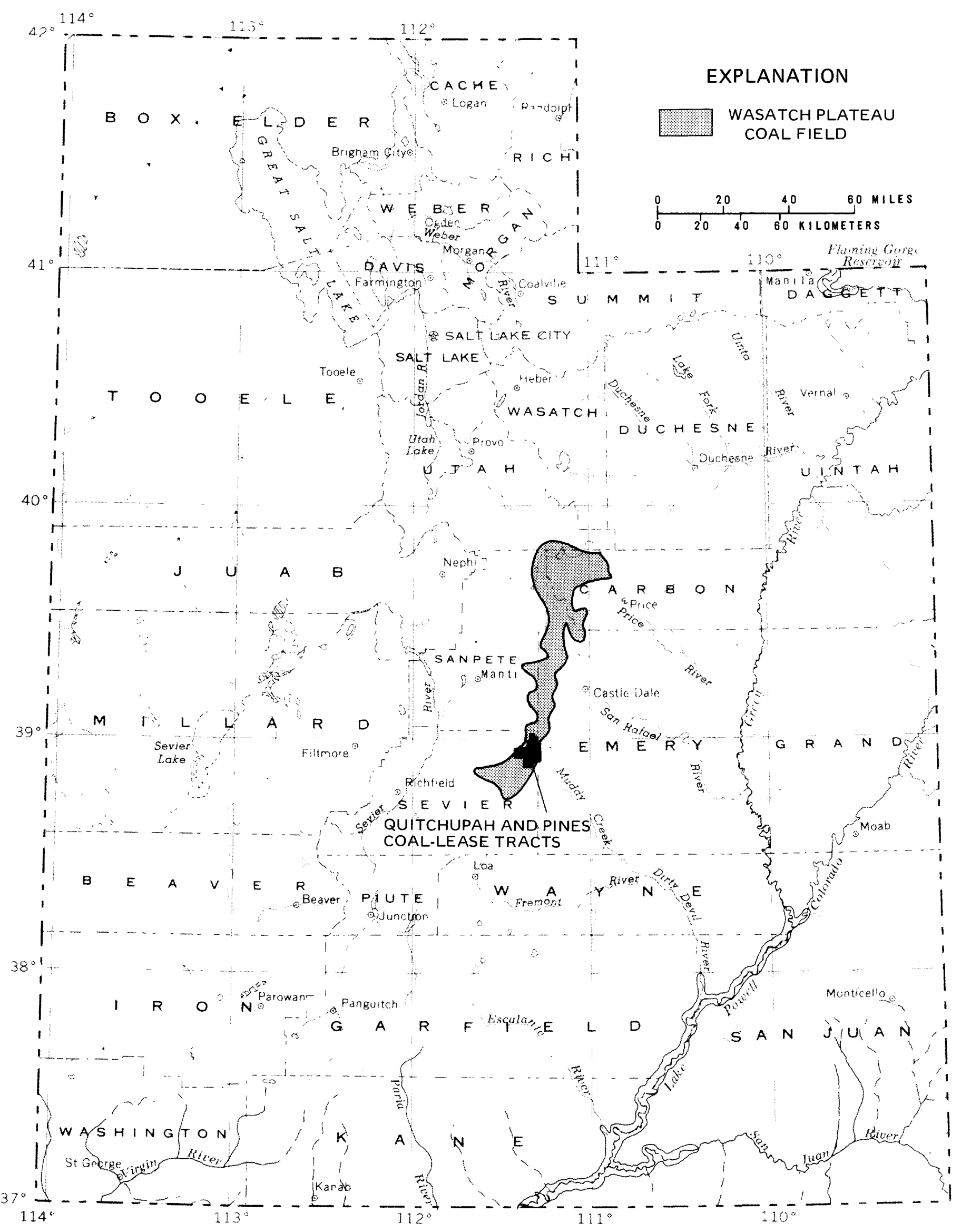

Figure 1.-- Location of the Wasatch Plateau coal field and the Quitchupah and Pines coal-lease tracts. 


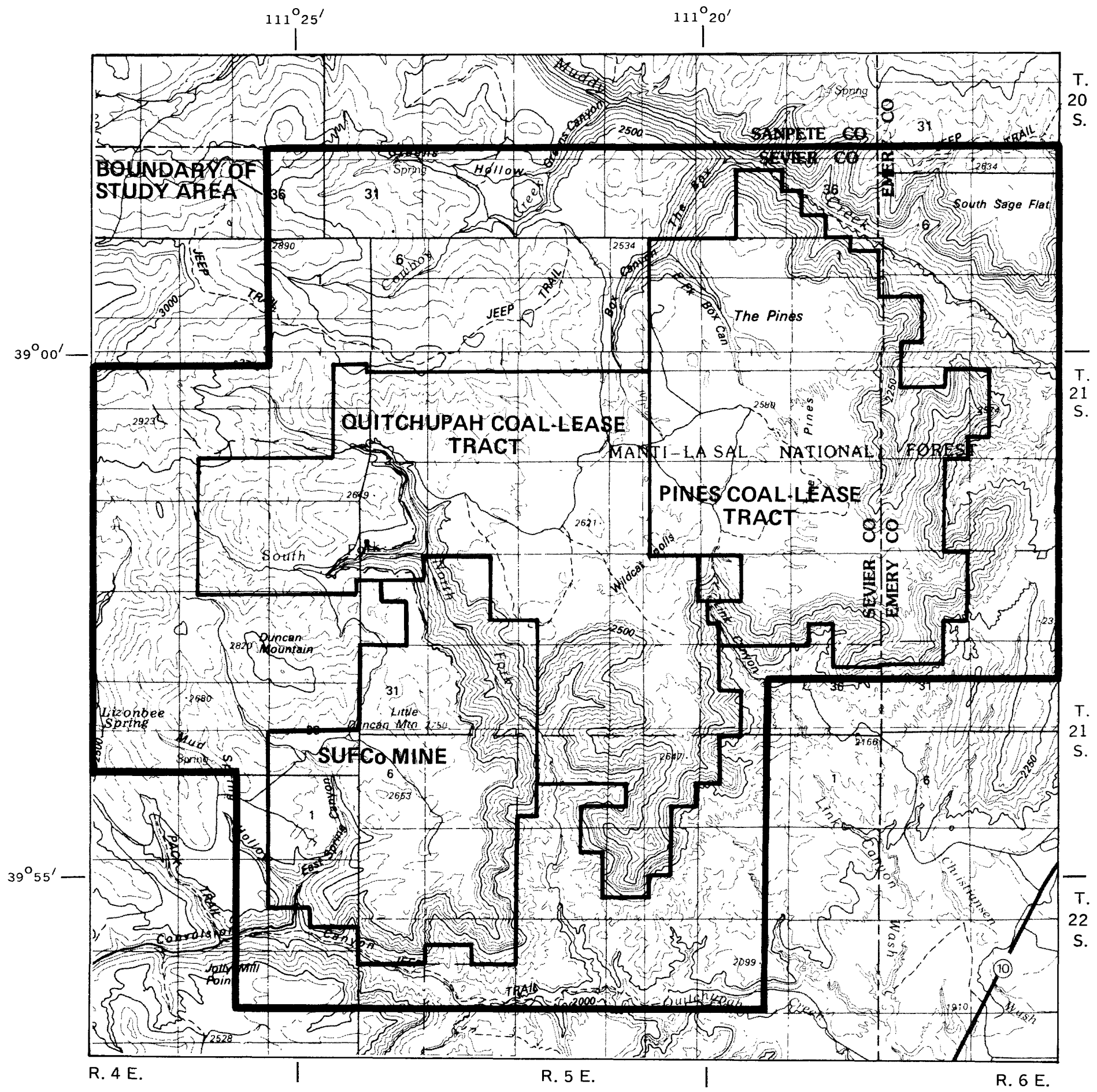

Base from U.S. Geological Survey 1:100,000

quadrangles, Salina, 1980 and Manti, 1981

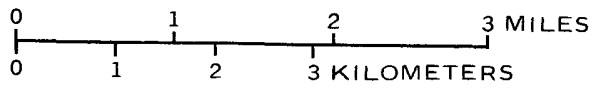

CONTOUR INTERVAL 50 METERS

NATIONAL GEODETIC VERTICAL DATUM OF 1929

Figure 2.--Location of the Quitchupah and Pines coal lease tracts, the tract containing the Southern Utah Fuel Co. (SUFCo) mine, and the boundary of the study area. 
The area of study was extended to include hydrologic-data sites outside the coal-lease tracts in order to help define the ground-water system. In this report, the Quitchupah and Pines study area includes the coal-lease tracts, in addition to the surrounding areas shown on figure 2 and plate 1.

\section{Ground-Water Site-Numbering System}

The system of numbering wells, springs and other ground-water sites in Utah is based on the cadastral land-survey system of the U.S. Government. The number, in addition to designating the site, describes its position in the land net. By the land-survey system, the State is divided into four quadrants by the Salt Lake Base Line and Meridian, and these quadrants are designated by the upper-case letters A, B, C, and D, indicating the northeast, northwest, southwest, and southeast quadrants, respectively. Numbers designating the township and range (in that order) follow the quadrant letter, and all three are enclosed in parentheses. The number after the parentheses indicates the section, and is followed by three letters indicating the quarter section, the quarter-quarter section, and the quarter-quarter-quarter section-generally 10 acres $^{1}$. The letters $a, b, c$, and $d$ indicate, respectively, the northeast, northwest, southwest, and southeast quarters of each subdivision. The number after the letters is the serial number of the well or spring within the 10acre tract. The letter " $S$ " preceding the serial number denotes a spring. If a well or spring cannot be located within a 10-acre tract, one or two location letters are used and the serial number is omitted. Thus,

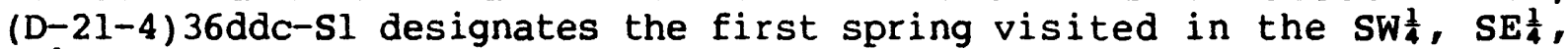
$\mathrm{SE} \frac{1}{4}, \mathrm{sec} .36, \mathrm{~T} .21 \mathrm{~S} ., \mathrm{R} .4 \mathrm{E}$. Other sites where hydrologic data were collected are numbered in the same manner, but three letters are used after the section number and no serial number is used. The numbering system is illustrated in figure 3.

\section{Acknowledgments}

The authors express appreciation to Chris Kravits, geologist for Southern Utah Fuel Company and Keith Welch, environmental coordinator for Coastal States Energy Company, for their cooperation and for arranging access to the SUFCo mine and monitoring wells. Data provided by the Coastal States Energy Company from the SUFCo mine and the surrounding areas was greatly appreciated.

\section{Physical Setting}

The Quitchupah and Pines coal-lease tracts are located primarily in the northeastern corner of Sevier County with the eastern part of the Pines coallease tract extending into Emery County (fig. 2). The Quitchupah coal-lease tract covers about $15.8 \mathrm{mi}^{2}$, and the pines tract covers about $13.9 \mathrm{mi}^{2}$. The Quitchupah coal-lease tract is adjacent to a $9.2 \mathrm{mi}^{2}$ area currently being mined for coal by the Southern Utah Fuel Company (SUFCo), a subsidiary of Coastal States Energy Company (fig. 2).

${ }^{1}$ Although the basic land unit, the section, is theoretically 1 square mile, many sections are irregular. Such sections are subdivided into 10-acre tracts, generally beginning at the southeast corner, and the surplus or shortage is taken up in the tracts along the north and west sides of the section. 
Sections within a township

R. 4 E.

\begin{tabular}{|c|c|c|c|c|c|}
\hline 6 & 5 & 4 & 3 & 2 & 1 \\
\hline 7 & 8 & 9 & 10 & 11 & 12 \\
\hline 18 & 17 & 16 & 15 & 14 & 13 \\
\hline 30 & 29 & 28 & 27 & 26 & 25 \\
\hline 31 & 32 & 33 & 34 & 35 & 36 \\
\hline
\end{tabular}

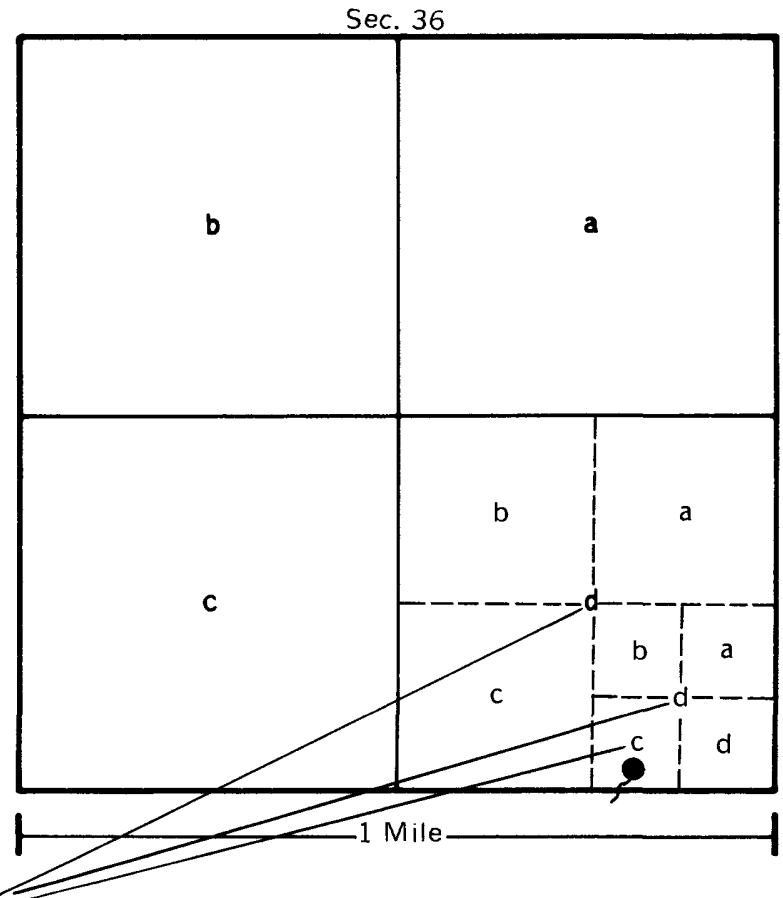

Tracts within a section

$\sec 36$

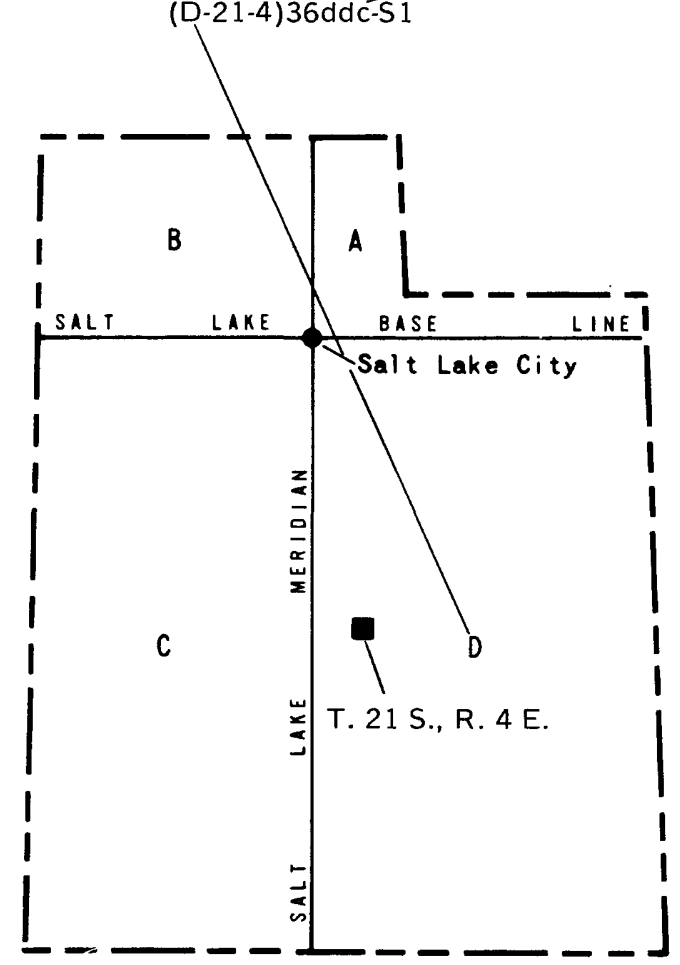

Figure 3.--Ground-water site numbering system used in Utah. 


\section{Topography and Drainage}

The study area is in the central Wasatch Plateau, a broad, flat-topped feature which slopes gently westward. Streams have cut deep, steep-sided canyons into the plateau (fig. 4). Surface relief in the study area varies from the relatively flat plateau top formed on the Castlegate sandstone and the Price River Formation to the steep canyon exposures of the Blackhawk Formation and the Star Point Sandstone. Relief in the coal-lease tracts is about 2,200 ft with the lowest point being 6,840 ft along North Fork of Quitchupah Creek above East Fork and the highest point at Wildcat Knolls, an elevation of $9,029 \mathrm{ft}(\mathrm{pl} .1)$.

All streams draining the study area eventually drain into the Dirty Devil River (fig. 1). Muddy Creek (pl. 1) to the north, drains most of the Pines coal-lease tract and Quitchupah Creek (pl. 1) to the south, drains the Quitchupah coal-lease tract and the area above the SUFCo mine. Link Canyon wash (pl. 1) drains a small area at the boundary between the Quitchupah and Pines coal-lease tracts.

Drainage patterns in the study area are affected by a fracture system observed in the Castlegate Sandstone, Blackhawk Formation, and the Star Point Sandstone. The system is oriented at about $\mathrm{N} 20^{\circ} \mathrm{W}$ to $\mathrm{N} 27^{\circ} \mathrm{W}$ (fig. 5), and it has locally altered the orientation of North Fork Quitchupah Creek near SW17 where the channel intersects massive beds of Star point Sandstone containing the fractures.

\section{Climate}

Normal annual precipitation in the study area ranges from about 12 in. (semiarid) at the lower altitudes to more than $20 \mathrm{in.} \mathrm{(subhumid)} \mathrm{at} \mathrm{the} \mathrm{higher}$ altitudes. Nomal May-September precipitation, from the lowest to the highest altitude in the study area, ranges from 6 to 10 in. (U.S. Weather Bureau, 1963). Annual free water surface evaporation for the area is about 40 in. (Farnsworth and others, 1982, map 3).

Localized thunderstorms occur from July through November and ontribute about half of the total annual precipitation. In the study area, the intensity of a 1-hour storm with a recurrence interval of 2 years is about $0.60 \mathrm{in} / \mathrm{hr}$, that of a 1-hour storm with a 100-year recurrence interval is about $1.53 \mathrm{in} / \mathrm{hr}$ (Miller and others, 1973, table 11 and figures 19, 24, 25, and 30 ).

Climatic conditions at the Emery $15 \mathrm{SW}$ weather station, about 11 miles south of the coal-lease tracts, closely represent average climatic conditions in the study area (fig. 6). The station is at an elevation of 7,640 ft. From November through March, the mean monthly temperature is below freezing. Mean monthly precipitation ranges from $0.75 \mathrm{in}$. in June to $1.97 \mathrm{in}$. in March. Average annual precipitation from 1980-85 was 15.6 in. Snow depths for April 1 recorded at the Blacks Fork snow course, about 3 miles northwest of the study area at an elevation of 9,200 ft, averaged $44 \mathrm{in}$. from 1945-85. The average water content of the snow was 14.4 in. (Whaley and Lytton, 1979 and U.S. Department of Agriculture, Soil Conservation Service, written commun., 1987). 


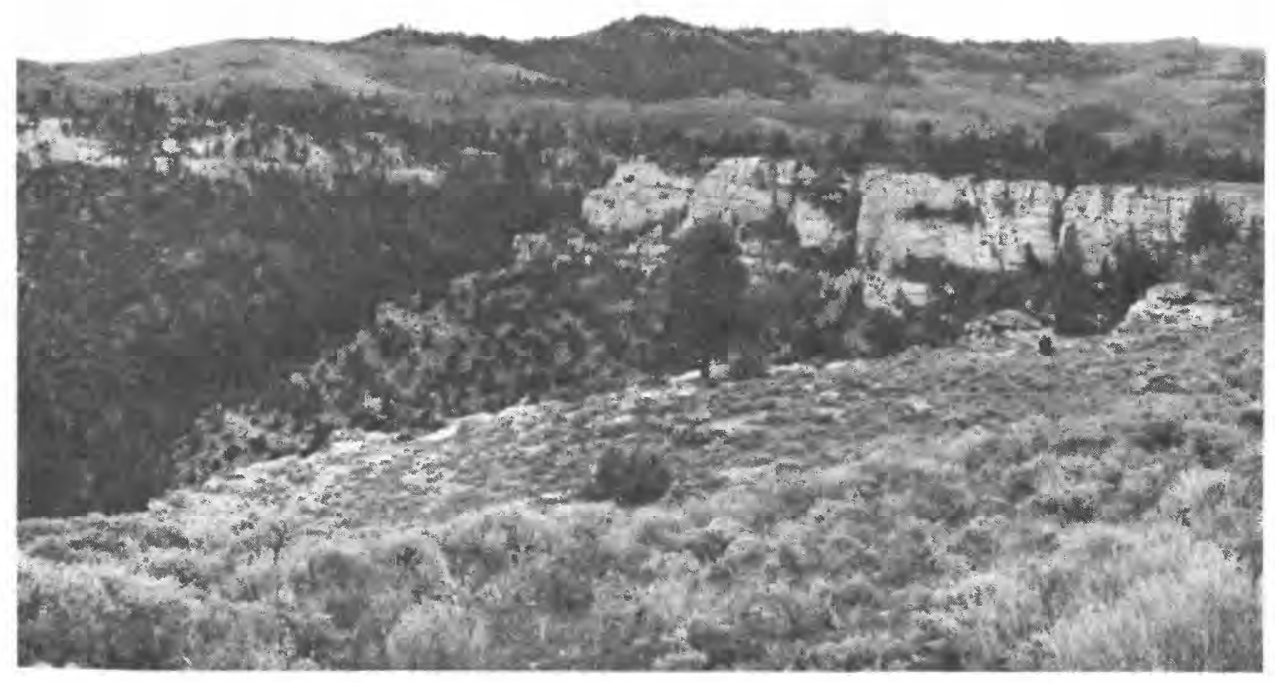

Figure 4.--Typical topography and vegetative cover of the Quitchupah and Pines study area.

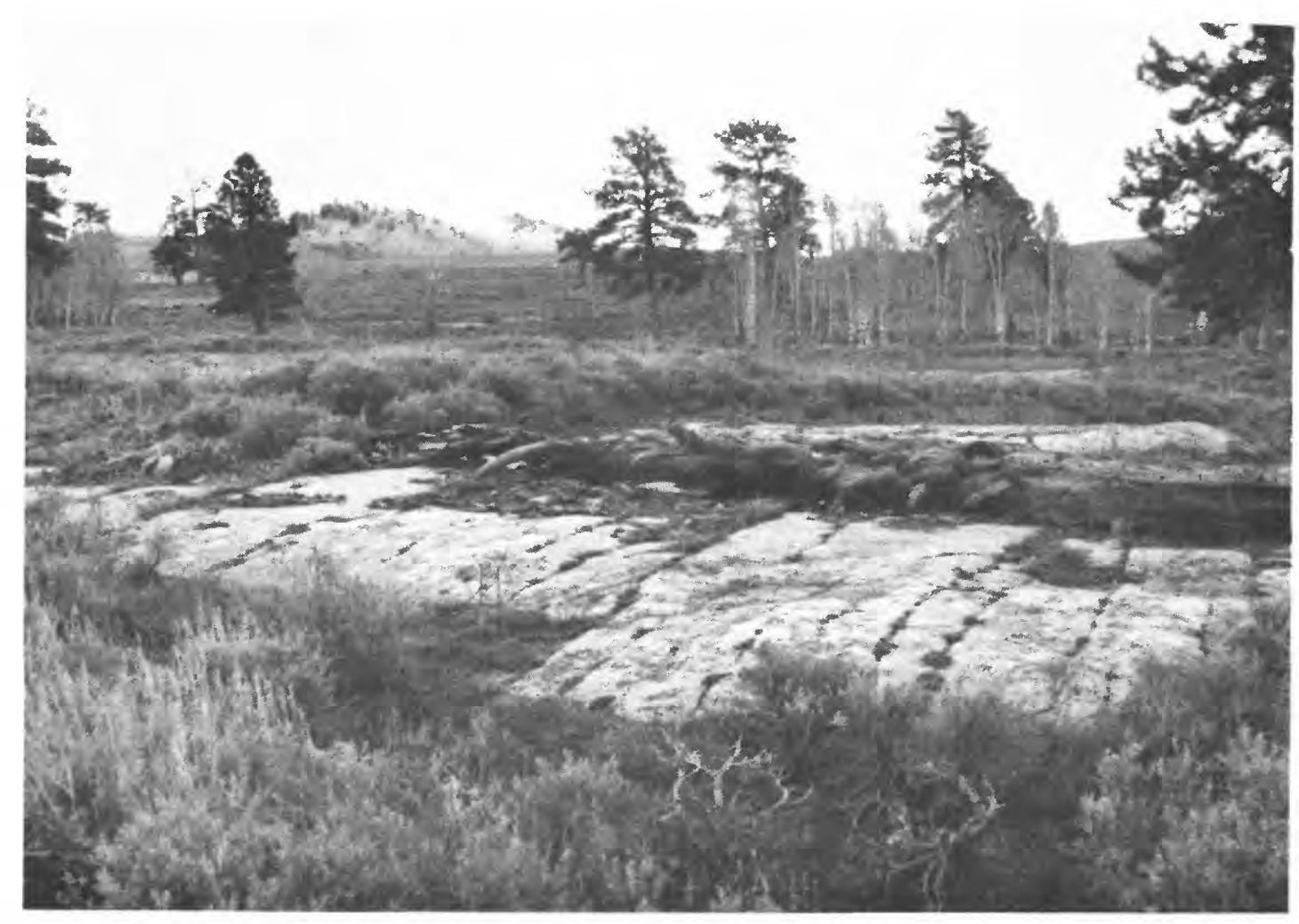

Figure 5.--Predominant fracture pattern in a Castlegate Sandstone outcrop near North Fork Quitchupah Creek. Fracture orientation at this location is $\mathrm{N} 22^{\circ} \mathrm{W}$. 

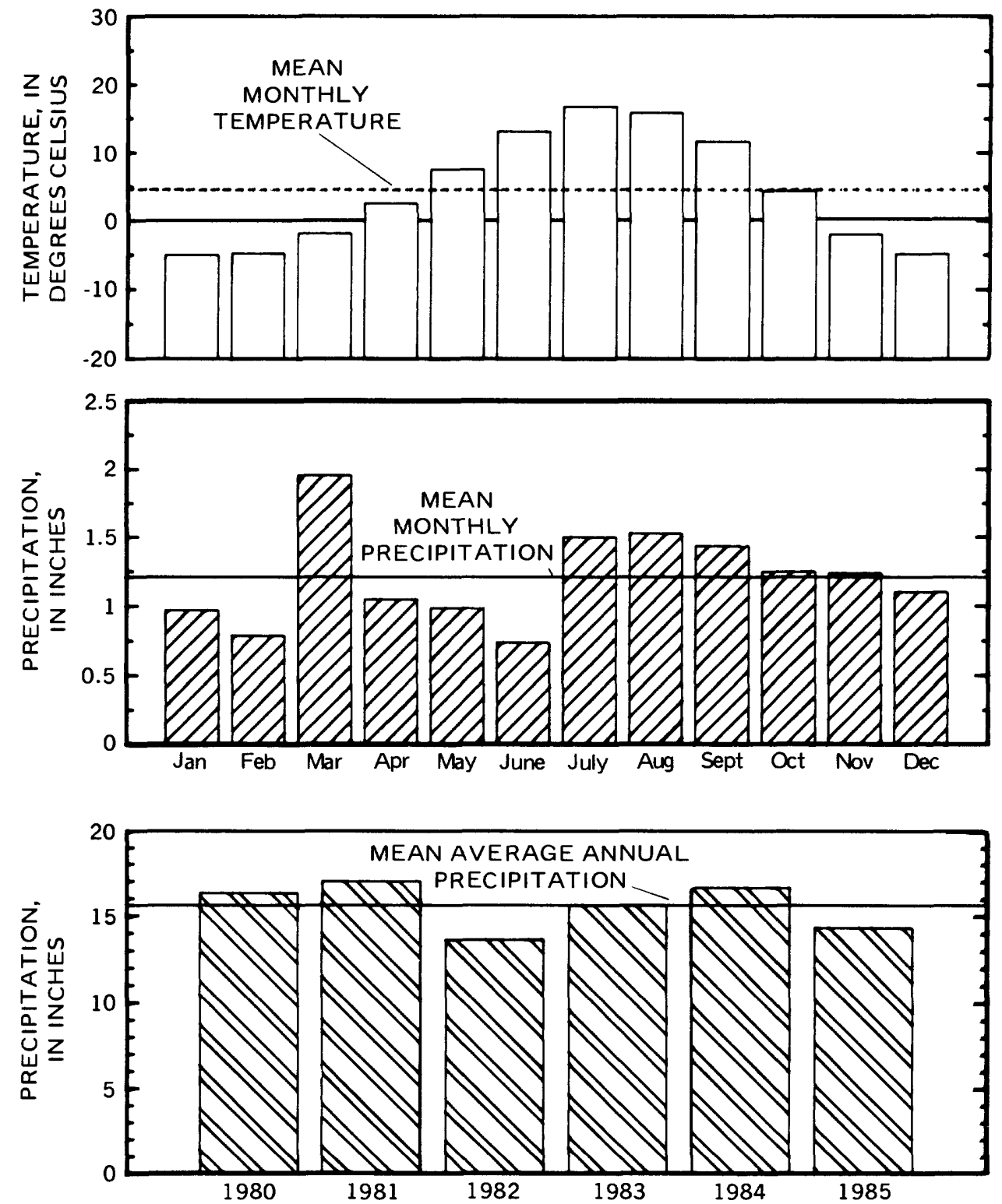

Figure 6.--Average monthly temperature and precipitation, 1979-86, and annual precipitation, 1980-85, at Emery 15 SW weather station (Data from National Oceanic and Atmospheric Administration, 1979-86). 


\section{Geology and Structure}

The strata exposed in the study area (fig. 7 and pl. 1), are sedimentary in origin and range in age from Late Cretaceous to early Tertiary. The Cretaceous Mancos Shale, the oldest formation exposed in the study area, includes, in ascending order, the Blue Gate, Emery Sandstone, and Masuk Members. These shale and sandstone members crop out near the eastern and southern edge of the coal-lease tracts.

The Masuk Member crops out extensively in Convulsion Canyon and along the North Fork Quitchupah Creek and Muddy Creek. The Masuk Member is a darkgray marine shale forming the upper 800 to $900 \mathrm{ft}$ of the Mancos Shale, and it is easily eroded where the harder overlying strata have been removed.

Formations of the Late Cretaceous Mesaverde Group overlie the Mancos Shale and include, from oldest to youngest, the Star Point Sandstone, the Blackhawk Formation, the Castlegate Sandstone, and the Price River Formation. These formations crop out in the canyons and at the higher altitudes of both tracts.

The Star Point Sandstone overlies and intertongues with the Masuk Merber of the Mancos Shale. The Star Point Sandstone, a prograding, nearshore beach deposit, underlies the Blackhawk Formation coal deposits. The base of the Star Point Sandstone consists of thin interbedded sandstone, siltstone, and shale. These strata grade upward into the first of three massive gray to white sandstone layers of which the uppermost prominent sandstone intertongues with the Blackhawk Formation. The thickness of the Star Point Sandstone is about $280 \mathrm{ft}$. It is present throughout the study area.

The Blackhawk Formation is characterized by facies changes representing a delta-plain depositional environment. The lower slope-forming part contains thin sandstone units and much carbonaceous shale and coal. The upper part has less carbonaceous shale, thinner coal seams, and massive cliff-forming sandstone units (Johnson, 1978). These sandstone units are grayish-orange to gray in color and are fine- to medium-grained. The Hiawatha coal seam, of commercial interest, averages about $7 \mathrm{ft}$ thick in the area (Smith, 1981, p. $6)$, and generally is found directly above the Star Point Sandstone. The thickness of the Blackhawk Formation ranges from about 790 to $920 \mathrm{ft}$, and it is present throughout the study area.

The Castlegate Sandstone, a coarse-grained fluvial sandstone, overlies the Blackhawk Formation. The Castlegate Sandstone is 100 to $200 \mathrm{ft}$ thick in the study area and forms massive white to grayish-orange cliffs when seen in outcrop. It is present over about 75 percent of the two coal-lease tracts.

The Price River Formation consists of gray to brown, medium- to coarsegrained sandstone, interbedded shale, and some thin beds of conglomerate. It forms a steep, receding slope above the Castlegate Sandstone or is spread out over hilly areas (Spieker, 1931). The Price River Formation has been eroded over much of the study area, but where it is overlain by younger formations elsewhere in the Wasatch Plateau, it ranges in thickness from 600 to 1,000 ft. The Price River Formation is present in about 50 percent of the Quitchupah lease tract and in about 25 percent of the Pines lease tract. 


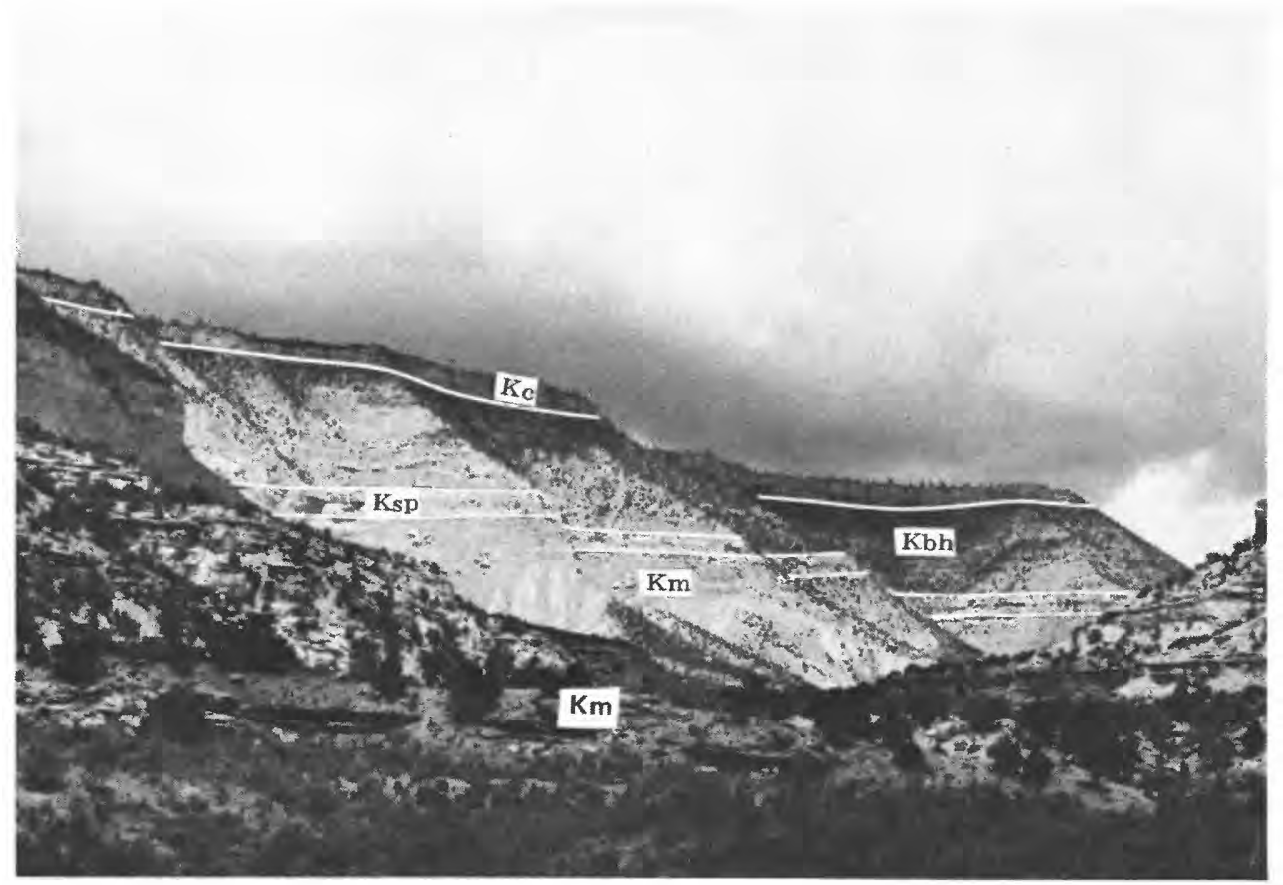

Figure 7.--View (facing west) of some of the geologic formations exposed in the Quitchupah and Pines study area (geologic units: Kc, Castlegate Sandstone; Kbh, Blackhawk Formation; Ksp, Star Point Sandstone; Km, Mancos Shale).

Overlying the Price River Formation is the Late Cretaceous and Paleocene North Horn Formation, consisting of slope-forming gray, purple, red, and brown shale interlayered with thin beds of sandstone and limestone. The weathered shale can be unstable as evidenced by slumping near Duncan Draw. The North Horn Formation ranges from 900 to 2,000 ft in thickness over the Wasatch Plateau (Davis and Doelling, 1977, p. 6), but within the two coal-lease tract areas much of that thickness has been removed by erosion. The formation crops out only at the tops of isolated knolls and in the far western part of the Quitchupah lease tract and the adjacent area.

The Paleocene and Eocene Flagstaff Limestone overlies the North Horn Formation just west of the coal-lease tracts. It mainly consists of freshwater limestone with same thin beds of shale. The Flagstaff Limestone weathers to a light-gray or cream oolor and forms the praminent cliffs capping the upper reaches of the Wasatch Plateau.

The strata in the area dip toward the northwest at about 2 degrees (Smith, 1981), but normal faulting has locally altered this regional trend. Faults oriented approximately north-south are common on the Wasatch Plateau. At Accord Lakes, about 6 miles southwest of the Quitchupah coal-lease tract, normal faulting has created a closed basin with at least $200 \mathrm{ft}$ of vertical offset (Spieker, 1931). Lizonbee Springs are the result of ground-water discharge along this fault (pl. 1). According to Chris Kravits, SUFCo 
mine geologist, (oral commun., August 26, 1987) most of the faults encountered within the SUFCo mine have less than $1 \mathrm{ft}$ of displacement, although $16 \mathrm{ft}$ of displacement in the subsurface was noted on a fault near Duncan Draw. Other faulting is inferred from geophysical logs and anomalous strikes and dips in the vicinity of Mud Spring Hollow (Smith, 1981).

Primary fracture orientation measured in the SUFCo mine is about $\mathrm{N} 26^{\circ} \mathrm{W}$. A secondary set of fractures measured at an outcrop of Castlegate Sandstone has an orientation of about $\mathrm{N} 65^{\circ} \mathrm{E}$.

\section{Soils and Vegetation}

Three types of soils have been mapped in the study area: canyons, tablelands, and benchlands (Rapin, 1977). In the deep, steep-sided canyons that cut through the Star Point Sandstone, Blackhawk Formation, and Castlegate Sandstone, soils generally are very thin (0-10 in.) and contain rock fragments. Up to 70 percent of this category is rock outcrops. On the tablelands, the slopes are gentler, and soils have predominantly formed on the Price River Formation. These soils are thin (10-20 in.) to moderately thick (20-40 in.) and generally have a substantial erosion hazard if the plant cover is removed (Rapin, 1977, p. 25).

On the benchlands and mountainsides in the northwestern part of the study area, soils have formed on the North Horn Formation (Rapin, 1977, p. 22). These soils are highly variable in thickness and texture but generally have a high rock-fragment content. These soils are unstable, sensitive to disturbance, and have a high erosion hazard (Rapin, 1977, p. 23).

The type and density of vegetative cover affects the quantity of sediment removed by overland runoff, as well as the quantity of surface-water infiltration. The relatively large change in elevation allows for much diversity in vegetative types near and within the study area. At the base of the cliffs and part way up the canyons grow scattered pinyon pine and juniper, with stands of Ponderosa pine, Douglas fir, and quaking aspen growing along the rim of the plateau. On the flat plateau top, forbs, grasses, and sagebrush provide forage for both wildlife and domestic livestock. At the higher elevations in the area, Englemann spruce and subalpine fir are the predominant conifers with some stands of quaking aspen. Phreatophytes such as Gambel's oak, serviceberry, elderberry, gooseberry, and various other mountain shrubs are found near drainages throughout the study area.

\section{Land Use}

The Quitchupah and Pines coal-lease tracts are mostly within National Forest boundaries. The Manti-Ia Sal and Fishlake National Forests administer the land's resources including recreation, grazing, wildlife, timber, and minerals. Camping, sightseeing, hiking, wood gathering, and hunting are some of the recreational activities available in the area. During the summer, much of the range in the study area is used for livestock grazing. Timber production has occurred recently on the relatively flat uplands. The SUFCo coal mine is actively mining in the southern part of the study area. The inactive Link Canyon Mine, located near both of the proposed coal-lease tracts (pl. 1), produced about 149,000 metric tons of coal between 1940 and 1952 (Doelling, 1972). 


\section{SURFACE-WATER HYDROLOGY}

\section{Discharge}

Surface water in the Quitchupah and Pines study area drains to Muddy Creek on the north and Quitchupah Creek on the south (fig. 2). Muddy Creek is fed by several tributaries which extend into the higher mountains southwest of the creek. Cowboy Creek and Box Canyon creek, in addition to the ephemeral Wileys Fork and Wash Rock Canyon, drain into Muddy Creek north of the coallease tracts (pl. 1).

U.S. Geological Survey streamflow-gaging station, Muddy Creek near Emery, Utah (09330500), has 37 years (to 1987) of continuous record. The gaging station is located $2 \mathrm{mi}$ east of the Pines coal-lease tract. Annual mean discharge for this period ranges from $8.89 \mathrm{ft}^{3} / \mathrm{s}$ in 1977 to $85.4 \mathrm{ft}^{3} / \mathrm{s}$ in 1983 (fig. 8). Peak flows usually oocur in May and June in response to highelevation snowmelt. Thunderstorms can cause short-term high flows in the late summer and fall. Runoff from the northern part of the study area during the water year 1986, as measured at the gaging station, was $48.1 \mathrm{ft}^{3} / \mathrm{s}$, slightly more than the average for the water years 1950-85, which was $39.8 \mathrm{ft}^{3} / \mathrm{s}$ (fig. 9).

North and South Forks of Quitchupah Creek, both perennial streams, begin west of the Quitchupah coal-lease tract on the east flank of the Wasatch Plateau and are the major contributors of flow to Quitchupah creek in Convulsion Canyon (pl. 1). Both forks derive flow from snowmelt runoff, ground-water seepage, and frequent thunderstorms. Continuous streamflowgaging stations were installed by the SUFCo mine on South Fork (site SW-11), North Fork (site SW-2), and on North Fork above the confluence with Quitchupah Creek (site SW-22) in June 1980. The period of record for these gages is intermittent and all were discontinued between 1982 and 1986 because of washouts resulting from spring runoff or flash floods. The SUFCo mine staff is currently (1987) measuring flow at these sites three times per year.

Box Canyon creek and East Fork Box Canyon creek are perennial where the base of the Castlegate Sandstone intersects the creeks and springs and seeps issue from the Castlegate and from underlying strata. Ephemeral streams in the area, as in Link Canyon, may have short reaches of year-round flow below springs and seeps.

The estimated peak and average streamflows for the drainages in the study area can be computed using regression equations developed by Thomas and Lindskov (1983, tables 5 and 6) and Christensen and others (1986, table 3). Equations used to determine peak and average streamflows are shown in table 1. The variables needed to complete the equations are the contributing drainage basin area, the mean basin altitude, the mean annual precipitation, and the main-channel slope. Equation set $A$ was used for mean basin altitudes greater than 8,000 ft, where peak flows are caused primarily by snowmelt; equation set $B$ was used for mean basin altitudes less than 8,000 ft, where peak flows are generally due to thunderstorms; and equation set $C$ was used to determine average streamflow. 
DISCHARGE, IN CUBIC FEET PER SECOND

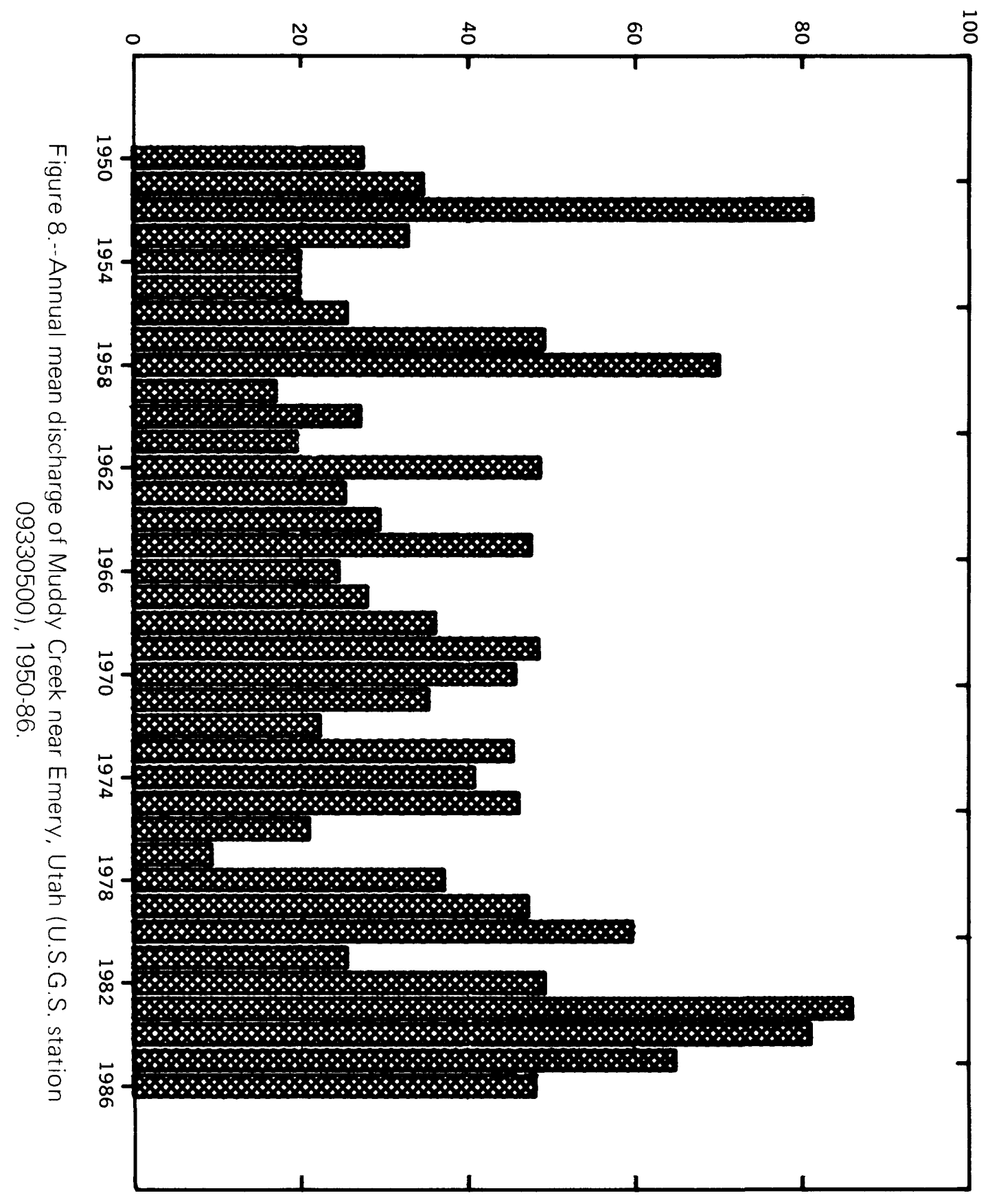




\section{EXPLANATION}

MONTHLY MEAN DISCHARGE FOR WATER YEAR 1986

MEAN MONTHLY DISCHARGE FOR WATER YEARS 1950-85

- - - ANNUAL MEAN DISCHARGE FOR WATER YEAR 1986

MEAN ANNUAL DISCHARGE FOR WATER YEARS 1950-85

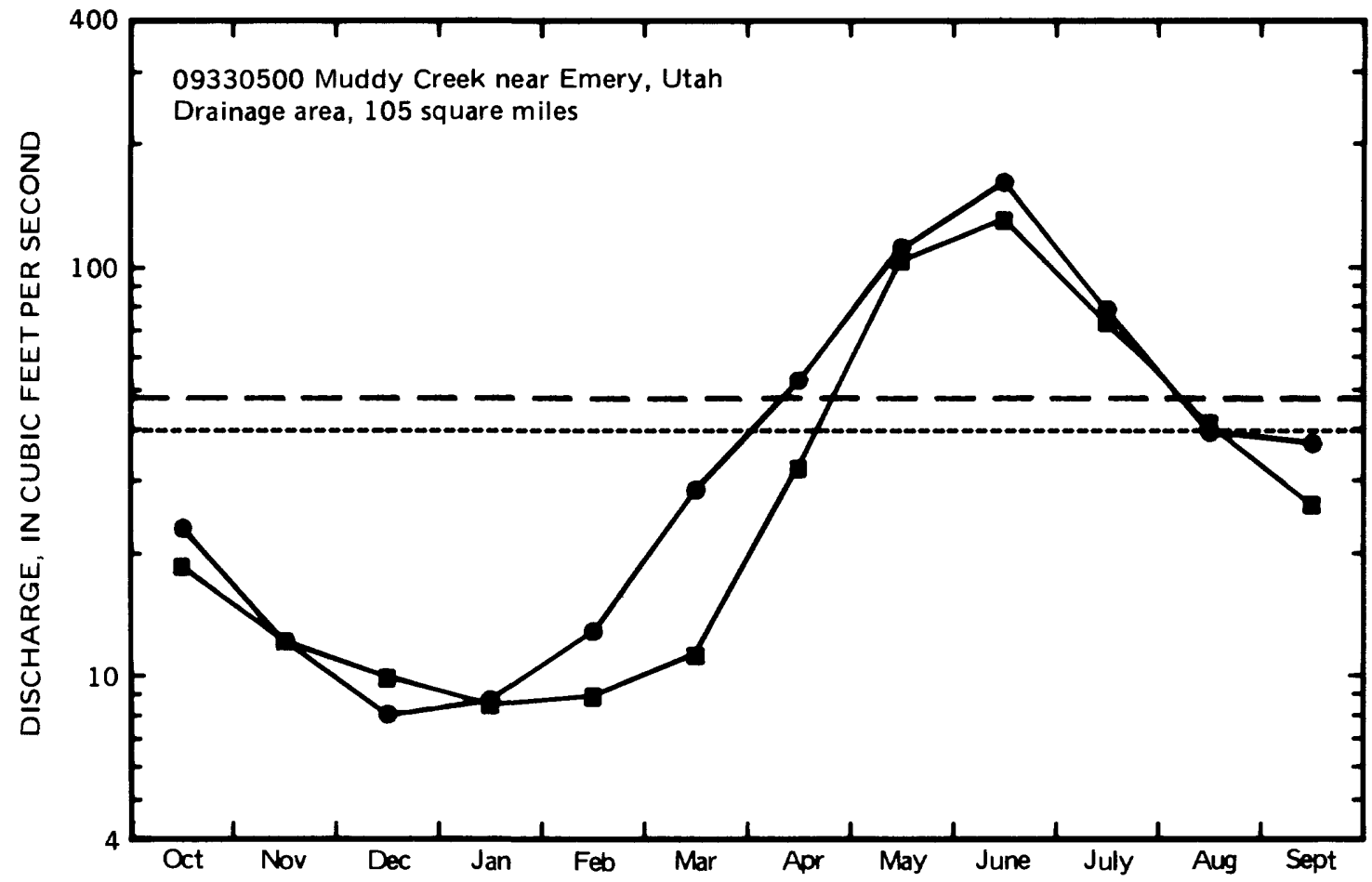

Figure 9.--Monthly mean and annual mean discharge for water year 1986, and mean monthly and mean annual discharge for water years 1950-85 at the Muddy Creek gaging station. 
The contributing drainage area, in square miles, $A$, is determined by planimetering or digitizing the area on a topographic map. The mean basin altitude, in thousands of feet, $E$, is determined by using a transparent grid over the map. The altitudes of a minimum of 20 equally spaced points are tabulated and the average of the points is determined. The mean annual precipitation, in inches per year, $P$, is obtained from a U.S. Weather Bureau map (1963). The main-channel slope in feet per mile, $S$, is the slope between two points at 10 and 85 percent of the maximum distance from the stream site to the drainage divide. It is computed by dividing the difference in altitude, in feet, by the distance, in miles, between the two points.

Using the equations in table 1 , average and 10-year peak flows were calculated for the perennial streams in the study area, North Fork Quitchupah Creek and Box Canyon creek, and for East Spring Canyon creek that traverses the area of the SUFCo mine (table 2).

\section{Water Quality}

Discharge, specific conductance, temperature, and suspended-sediment concentrations for water samples from 37 surface-water sites are shown in table 3. Dissolved-solids and major ion concentrations for water samples from 18 surface-water sites in and near the study area are shown in table 4 . Water samples fram five surface-water sites were analyzed during this study for the concentration of dissolved trace metals (table 4).

Specific conductance of surface water measured in or near the study area during the 1987 water year, October 1986 through September 1987, ranged from $440 \mu \mathrm{S} / \mathrm{cm}$ at Muddy Creek near Emery, Utah (09330500), to $860 \mu \mathrm{S} / \mathrm{cm}$ at site Sw18 below the SUFCo mine discharge portal on North Fork Quitchupah Creek. Specific conductance, a measure of the ability of water to conduct an electric current, provides an indication of the total dissolved-solids concentration because the presence of charged ionic species in solution makes the water conductive (Hem, 1985, p. 66). Limited data indicate that the specific conductance at site SW-22 on the North Fork Quitchupah Creek is related to the corresponding streamflow. As streamflow increases from spring snowmelt, specific conductance decreases as a result of dilution (fig. 10). During late summer and fall, when ground-water seepage contributes a major part of flow to the stream, specific conductance increases.

The concentration of chemical constituents in surface water is related to the concentration of chemical constituents in runoff and base flow and the quantity each contributes to streamflow. The type of chemical constituents in either runoff or base flow is usually a representation of the type of rock with which the water has been in contact.

The predominant chemical constituents found in surface water upstream from the lower part of the Blackhawk Formation in the Quitchupah Creek drainage area are calcium, magnesium, and bicarbonate plus carbonate. Surface water collected downstream, having flowed across the lower part of the Blackhawk Formation, Star Point Sandstone, and the upper part of the Mancos Shale, shows an increase in the concentration of sulfate. 
Table 1.--Regression equations used to compute peak and average streamflow from ungaged tributaries

of the Quitchupah and Pines study area

[Equation: Q, stream discharge, in cubic feet per second; A, drainage area, in square miles; E, mean basin altitude, in thousands of feet; $P$, mean annual precipitation, in inches; and S, main-channel slope, in feet per mile]

Recurrence

interval,

Equation

Source

in years

Set $A-Q$ is peak discharge where $E$ is greater than 8,000 feet

$10 Q=680\left(A^{0.706}\right)\left(E^{-1.30}\right) \quad$ Thamas and Lindskov, 1983, table 5 .

$50 Q=64,200\left(\mathrm{~A}^{0.651}\right)\left(\mathrm{E}^{-3.03}\right)$

$100 Q=347,000\left(A^{0.631}\right)\left(E^{-3.68}\right)$

Set $B-Q$ is peak discharge where $E$ is less than 8,000 feet

$\begin{array}{rl}10 & Q=23,700\left(A^{0.433}\right)\left(E^{-2.23}\right) \quad \text { Thomas and Lindskov, 1983, table } 6 . \\ 50 & Q=61,000\left(A^{0.375}\right)\left(E^{-2.19}\right) \\ 100 & Q=83,100\left(A^{0.356}\right)\left(E^{-2.17}\right)\end{array}$

Set $C-Q$ is average discharge

$-\quad Q=0.000208\left(A^{0.709}\right)\left(P^{1.46}\right)\left(S^{0.554}\right)$

Christensen and others, 1986, table 3. 
Table 2.--Calculated average and 10-year peak flows for perennial streams in the Quitchupah and Pines study area

\begin{tabular}{|c|c|c|c|c|c|c|c|}
\hline $\begin{array}{c}\text { site } \\
\text { number } \\
\text { (pl. 1) }\end{array}$ & Watershed & $\begin{array}{c}\text { Drainage } \\
\text { area } \\
\\
\text { (A) } \\
\text { (square } \\
\text { miles) }\end{array}$ & $\begin{array}{l}\text { Mean basin } \\
\text { altitude } \\
\text { (in thousands } \\
\text { of feet above } \\
\text { NGVD of 1929) } \\
\text { (E) }\end{array}$ & $\begin{array}{c}\text { Mean } \\
\text { annual } \\
\text { precip- } \\
\text { itation } \\
\text { (P) } \\
\text { (inches) }\end{array}$ & $\begin{array}{c}\text { Main- } \\
\text { channel } \\
\text { slope } \\
\text { (S) } \\
\text { (foot } \\
\text { per mile) }\end{array}$ & $\begin{array}{l}\text { Stream } \\
\text { Average } \\
\frac{(Q)}{\text { (cubi }} \\
\text { per }\end{array}$ & $\begin{array}{l}\text { discharge } \\
\begin{array}{c}\text { 10-year } \\
\text { peak }\end{array} \\
(Q) \\
\text { c feet } \\
\text { second) }\end{array}$ \\
\hline$S W-22$ & $\begin{array}{l}\text { North } \\
\text { Fork } \\
\text { Quitchupar }\end{array}$ & 23.4 & 8.3 & 19 & 300 & 3.4 & 402 \\
\hline$S W-34$ & $\begin{array}{l}\text { Box } \\
\text { Canyon }\end{array}$ & 12.0 & 8.4 & 18 & 230 & 1.7 & 247 \\
\hline$S W-25$ & $\begin{array}{l}\text { East } \\
\text { Spring } \\
\text { Canyon }\end{array}$ & 8.5 & 8.5 & 19 & 360 & 1.8 & 191 \\
\hline
\end{tabular}

A comparison of the chemical composition of water from site $5 \mathrm{~W}-22$ on North Fork Quitchupah Creek in the 1987 water year indicates how mixing of runoff and base flow can change water quality. In a sample collected on october 23, 1986, at a base flow of $1.6 \mathrm{ft} / \mathrm{s}$, the principal constituents in the water were calcium, magnesium, sulfate, and bicarbonate. In a sample collected on May 13, 1987, at a discharge of $4.8 \mathrm{ft}^{3} / \mathrm{s}$ (spring runoff), the concentration of magnesium had decreased 29 percent while sulfate decreased 57 percent compared to the October analyses. This change in chemical camposition is probably the result of a decrease in the percentage of ground water as a part of the total streamflow in May compared to October.

The one-to-one ratio of bicarbonate and sulfate found in water discharging from the SUFCo mine (site GN-24, pl. 1) into North Fork Quitchupah Creek on October 10, 1986, is about the same as that found at site $\mathrm{SN}-22$ on the North Fork Quitchupah Creek during base flow. The concentration of dissolved strontium in a sample collected on May 15, 1987, was found to be 1.5 to 2 times larger than concentrations in samples of base flow and of springs. Concentrations of all trace metals analyzed were below Federal maximum contaminant levels for drinking water (U.S. Enviromental Protection Agency, 1986). However, the increase in strontium is substantial and is thought to be related to the traverse of the stream across the Mancos Shale. The Mancos Shale contains soluble sodium sulfate minerals (Lines and Morrissey, 1983, p. 19), and is the most likely source of the additional strontium. Strontium sulfate (celestite) and strontium carbonate (strontianite) are common in sediments (Hem, 1985, p. 135) and probably occur in the Mancos Shale. 
Table 3.-Discharge, specific conductance, temperature, and concentration of suspended sediment in water from selected streams

$\left[\mathrm{ft}^{3} / \mathrm{s}\right.$, cubic feet per second; $\mu \mathrm{S} / \mathrm{cm}$, microsiemens per centimeter at 25 degrees Celsius;

${ }^{\circ} \mathrm{C}$, degrees Celsius; mg/L, milligrams per liter]

Geologic unit: TKnh, North Horn Formation; Kpr, Price River Formation; Kc, Castlegate Sandstone; Kbh, Blackhawk Formation; Ksp, Star Point Sandstone; Kmm, Masuk Member of Mancos Shale.

Discharge: Measured with a current meter or at a gaging station except where noted e (estimated).

Specific conductance: Measured in field except where noted $L$ (laboratory value). Dashes (--), not measured.

\begin{tabular}{|c|c|c|c|c|c|c|}
\hline General site description & $\begin{array}{l}\text { Site number } \\
\text { (see pl. 1) }\end{array}$ & Date & $\begin{array}{c}\text { Discharge } \\
\left(\mathrm{ft}^{3} / \mathrm{s}\right)\end{array}$ & $\begin{array}{l}\text { Specific } \\
\text { conductance } \\
(\mu \mathrm{S} / \mathrm{cm})\end{array}$ & $\begin{array}{c}\text { Temperature } \\
\left({ }^{\circ} \mathrm{C}\right)\end{array}$ & $\begin{array}{c}\text { Suspended- } \\
\text { sediment } \\
\text { concentration } \\
(\mathrm{mg} / \mathrm{L})\end{array}$ \\
\hline
\end{tabular}

Quitchupah Creek drainage

North Fork Quitchupah Creek

Below TKnh-Kpr contact

Above Kpr-Kc contact

Unnamed tributary

Below confluence of SW-2 and $\mathrm{SW}-3$

Below Kpr-Kc contact

Unnamed tributary

Below Kc-Kbh contact

Below SW-7

Be low SW-8

Unnamed tributary

South Fork Quitchupah Creek

Above Kpr-Kc contact
Below Kpr-Kc contact
Above confluence with North
Fork Quitchupah Creek

$\begin{array}{ll}\text { SW-11 } & 10-24-86 \\ & 09-10-87 \\ \text { SW-12 } & 11-07-78 \\ & 07-31-79 \\ & 08-21-80 \\ \text { SW-13 } & 11-07-78 \\ & 09-18-80\end{array}$

$\begin{array}{ll}\text { SW-1 } & 10-03-79 \\ \text { SW-2 } & 11-07-78 \\ & 08-01-79 \\ & 10-03-79 \\ & 08-21-80 \\ & 09-18-80 \\ & 09-04-86 \\ & 09-04-86 \\ \text { SW-3 } & 09-10-87 \\ \text { SW-4 } & 09-04-86 \\ & 10-24-86 \\ \text { SW-5 } & 09-10-87 \\ & 09-05-86 \\ & 09-11-87 \\ \text { SW-6 } & 09-04-86 \\ \text { SW-7 } & 11-07-78 \\ \text { SW-8 } & 11-07-78 \\ \text { SW-9 } & 09-18-80 \\ \text { SW-10 } & \end{array}$

0.14

0.13

0.61

0.28

$3 \mathrm{e}$

0.44

0.34

0.02

0.22

0.39

0.43

0.27

0.001

0.28

0.46

0.08

0.01

0.03

0.29

0.21

0.02

0.93

$3 e$

0.03

0.47

North Fork Quitchupah Creek

Above confluence with South
Fork Quitchupah Creek
Below confluence with South
Fork Quitchupah Creek
Below SW-15
Above SUFCo discharge portal
Below SUFCo discharge portal
Above Ksp-Kmm contact
Below Ksp-Kmm contact
Above confluence with
Quitchupah Creek

0.73

0.24

1.6

0.49

0.25

0.90

1.14

0.50

1.5

0.20

1.8

0.84

22.4

1.0

1.6

2.3

4.8

1.4

350
600
540
440
540
$570 \mathrm{~L}$
--
--
510
--
680
520
--
540
--
590
410
--

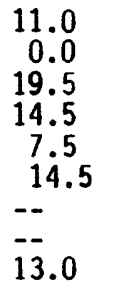

$-$

$-$

62

73

74

54

--

$-1.5$

98

14.5

8.0

170

0.0

0.0
7.5

169

70

$--$

$--$
1.5

12.0
0.0

15.0

6.0

0.0

6.5

$\begin{array}{rr}5.0 & -- \\ 17.5 & -- \\ 3.0 & -- \\ 15.0 & -- \\ 4.5 & -- \\ 19.0 & 41 \\ 8.0 & -- \\ 14.5 & -- \\ 14.0 & -- \\ 8.0 & -- \\ 15.0 & -- \\ 6.5 & -- \\ 11.0 & 10,900 \\ 15.0 & -- \\ 12.0 & 38 \\ 7.0 & -- \\ 13.0 & -- \\ 19.0 & --\end{array}$


Table 3.-Discharge, specific conductance, temperature, and concentration of suspended sediment in water from selected streams--Continued

\begin{tabular}{|c|c|c|c|c|c|c|}
\hline General site description & $\begin{array}{l}\text { Site number } \\
\text { (see pl. 1) }\end{array}$ & Date & $\begin{array}{c}\text { Discharge } \\
\left(\mathrm{ft}^{3} / \mathrm{s}\right)\end{array}$ & $\begin{array}{l}\text { Specific } \\
\text { conductance } \\
(\mu \mathrm{S} / \mathrm{cm})\end{array}$ & $\begin{array}{c}\text { Temperature } \\
\left({ }^{\circ} \mathrm{C}\right)\end{array}$ & $\begin{array}{c}\text { Suspended- } \\
\text { sediment } \\
\text { concentration } \\
(\mathrm{mg} / \mathrm{L})\end{array}$ \\
\hline \multicolumn{7}{|c|}{ Quitchupah Creek drainage--Continued } \\
\hline \multicolumn{7}{|l|}{ Quitchupah Creek } \\
\hline \multicolumn{7}{|l|}{ East Spring Canyon Creek } \\
\hline $\begin{array}{l}\text { Above SUFCo mine } \\
\text { Below SUFCo mine } \\
\text { Quitchupah Creek }\end{array}$ & $\begin{array}{l}\text { SW-24 } \\
\text { SW-25 }\end{array}$ & $\begin{array}{l}10-17-78 \\
05-02-79 \\
08-02-79 \\
09-17-80\end{array}$ & $\begin{array}{l}0.63 \\
-- \\
0.64 \\
0.13\end{array}$ & $\begin{array}{l}650 \\
175 \\
790 \\
900\end{array}$ & $\begin{array}{r}12.5 \\
2.0 \\
16.0 \\
13.5\end{array}$ & $\begin{array}{l}-- \\
-- \\
--\end{array}$ \\
\hline \multicolumn{7}{|c|}{ Muddy Creek drainage } \\
\hline $\begin{array}{l}\text { The Box below confluence of } \\
\text { Box Canyon and East Fork } \\
\text { Box Canyon }\end{array}$ & SW-31 & $09-17-86$ & 0.25 & -- & -- & 171 \\
\hline Cowboy Creek at road crossing & SW-32 & $08-04-86$ & 0.11 & 830 & 24.0 & 75 \\
\hline Muddy Creek above The Box & SW-33 & $10-18-78$ & 24.2 & 400 & 7.5 & -- \\
\hline $\begin{array}{l}\text { The Box above conf luence } \\
\text { with Muddy Creek }\end{array}$ & SW-34 & $\begin{array}{l}10-18-78 \\
09-18-80\end{array}$ & $\begin{array}{l}0 \\
0.20\end{array}$ & -- & $13 . \overline{-}$ & -- \\
\hline
\end{tabular}


Table 3.-Discharge, specific conductance, temperature, and concentration of suspended sediment in water from selected streams--Continued

\begin{tabular}{|c|c|c|c|c|c|c|}
\hline General site description & $\begin{array}{l}\text { Site number } \\
\text { (see pl. 1) }\end{array}$ & Date & $\begin{array}{l}\text { Discharge } \\
\left(\mathrm{ft}^{3} / \mathrm{s}\right)\end{array}$ & $\begin{array}{l}\text { Specific } \\
\text { conductance } \\
(\mu \mathrm{S} / \mathrm{cm})\end{array}$ & $\begin{array}{c}\text { Temperature } \\
\left({ }^{\circ} \mathrm{C}\right)\end{array}$ & $\begin{array}{c}\text { Suspended- } \\
\text { sed iment } \\
\text { concentrat io } \\
(\mathrm{mg} / \mathrm{L})\end{array}$ \\
\hline \multicolumn{7}{|c|}{ Muddy Creek drainage--Cont inued } \\
\hline $\begin{array}{l}\text { Muddy Creek above Last } \\
\text { Water Canyon }\end{array}$ & SW-35 & $\begin{array}{l}08-16-79 \\
05-16-80 \\
08-20-80 \\
09-17-80\end{array}$ & $\begin{array}{l}51 \\
77 \\
50 e \\
30\end{array}$ & $\begin{array}{l}395 \\
460 \\
460 \\
430\end{array}$ & $\begin{array}{r}14.5 \\
8.5 \\
10.5 \\
12.0\end{array}$ & $\begin{array}{r}127 \\
312 \\
34 \\
--\end{array}$ \\
\hline $\begin{array}{l}\text { Last Water Canyon above } \\
\text { confluence with Muddy Creek }\end{array}$ & $S W-36$ & $\begin{array}{l}10-18-78 \\
09-18-80\end{array}$ & $\begin{array}{l}0.01 \\
0.10\end{array}$ & 580 & $\begin{array}{l}10.0 \\
17.0\end{array}$ & -- \\
\hline $\begin{array}{l}\text { Muddy Creek at gaging station } \\
09330500\end{array}$ & $\begin{array}{l}\text { Not shown } \\
\text { on p1. } 1\end{array}$ & $\begin{array}{l}09-18-80 \\
10-23-86\end{array}$ & $\begin{array}{l}29.9 \\
19.0 \mathrm{e}\end{array}$ & $\begin{array}{l}410 \\
440\end{array}$ & $\begin{array}{r}15.5 \\
6.5\end{array}$ & $\overline{24 \overline{6}}$ \\
\hline
\end{tabular}

Suspended-sediment concentrations in surface water from the Quitchupah Creek drainage ranged from 17 to $10,900 \mathrm{mg} / \mathrm{L}$. Within the Muddy Creek drainage, they ranged from 34 to $312 \mathrm{mg} / \mathrm{L}$ (table 3). Suspended-sediment concentration in Muddy Creek is probably not representative of the lease areas because Muddy Creek has a smaller stream gradient, and it drains a larger area with more extensive exposures of the North Horn and younger formations. The relation between stream discharge and suspended-sediment load (fig. 11) indicates that a discharge of about $7 \mathrm{ft}^{3} / \mathrm{s}$ in Quitchupah Creek is sufficient to move a suspended-sediment load about the same as that of Muddy Creek at a discharge of 19 to $51 \mathrm{ft}^{3} / \mathrm{s}$.

Suspended-sediment concentration is apparently related to discharge. Concentrations of suspended sediment measured at the Quitchupah Creek gaging station (09331850, SW-27) over a period of 4 years ranged from $17 \mathrm{mg} / \mathrm{L}$ at a discharge of $0.15 \mathrm{ft}^{3} / \mathrm{s}$ to $180 \mathrm{mg} / \mathrm{L}$ at a discharge of $1.5 \mathrm{ft}^{3} / \mathrm{s}$ ( $\mathrm{fig} .12$ ). The largest concentrations of suspended sediment in the area were measured in May 1980 during spring runoff. A concentration of $10,900 \mathrm{mg} / \mathrm{L}$ was measured for North Fork Quitchupah Creek (SW-22), and a concentration of $5,260 \mathrm{mg} / \mathrm{L}$ was measured for Quitchupah Creek $(S W-30)$. Nevertheless, sediment concentrations in streamflow are probably the largest as a result of runoff from intense rainfall during thunderstorms.

\section{Erosion and Estimated Sediment Yield}

The degree of erosion in an area determines the quantity of sediment contributed to a stream. Factors influencing erosion include the quantity and intensity of precipitation, temperature, type and density of vegetation, slope of the land surface, lithologic and structural character of the rocks, and the types of soil covering these rocks. More resistant rocks, such as limestone and dolomite, are found in the higher parts of the Wasatch Plateau. Less sediment would be eroded from these areas than from areas where less resistant strata (sandstone and shale) are exposed. The Castlegate Sandstone, Blackhawk Formation, and Star Point Sandstone crop out in deeply incised, steep-sided canyons in the study area and in some areas are covered with thin soils that allow water to run off rapidly and carry much sediment. 
Table 4.-Chemical analyses of wate [ $\mathrm{N} / \mathrm{on}$, microsiemens per centimeter at 25 degrees Celsius; ${ }^{\circ} \mathrm{C}$, degrees Celsius; $\mathrm{mg} / \mathrm{L}$, milligrams Specific conductance: Measured in field except where noted L (laboratory value).

\begin{tabular}{|c|c|c|c|c|c|c|c|c|c|c|c|c|c|}
\hline rean & $\begin{array}{c}\text { Site } \\
\text { number } \\
\text { (p1. 1) }\end{array}$ & Date & $\begin{array}{l}\text { Spe- } \\
\text { cific } \\
\text { conduct- } \\
\text { ance } \\
(\mu \mathrm{S} / \mathrm{cm})\end{array}$ & $\begin{array}{l}\text { pH } \\
\text { (stand- } \\
\text { ard } \\
\text { units) }\end{array}$ & $\begin{array}{c}\text { Temper- } \\
\text { ature } \\
\left({ }^{\circ} \mathrm{C}\right)\end{array}$ & $\begin{array}{l}\text { Hard- } \\
\text { ness, } \\
\text { noncar- Alka- } \\
\text { banate linity } \\
\left(\mathrm{mg}_{\mathrm{L}} \mathrm{L} \text { as }(\mathrm{mg} / \mathrm{L} \text { as }\right. \\
\left.\left.\mathrm{CaCO}_{3}\right) \quad \mathrm{CaCO}_{3}\right)\end{array}$ & $\begin{array}{l}\text { Solids, } \\
\text { sum of } \\
\text { consti- } \\
\text { tuents, } \\
\text { dis- } \\
\text { solved } \\
\text { (mg/L) }\end{array}$ & $\begin{array}{l}\text { Solids, } \\
\text { residue } \\
\text { at } 180 \\
{ }^{\circ} \mathrm{C} \\
\text { dis- } \\
\text { solved } \\
\text { (mg/L) }\end{array}$ & $\begin{array}{l}\text { Cal- } \\
\text { cium, } \\
\text { dis- } \\
\text { solved } \\
\text { (mg/L } \\
\text { as Ca) }\end{array}$ & $\begin{array}{l}\text { Magne- } \\
\text { sium, } \\
\text { dis- } \\
\text { solved } \\
(\mathrm{mg} / \mathrm{L} \\
\text { as } \mathrm{Mg})\end{array}$ & $\begin{array}{c}\text { Sodium, } \\
\text { dis- } \\
\text { solved } \\
\text { (mg/L } \\
\text { as } \mathrm{Na} \text { ) }\end{array}$ & $\begin{array}{l}\text { Potas- } \\
\text { sium, } \\
\text { dis- } \\
\text { solved } \\
\text { (mg/h } \\
\text { as } \mathrm{K} \text { ) }\end{array}$ & $\begin{array}{l}\text { sulfate, } \\
\text { dis- } \\
\text { solved s } \\
\text { (mg/L } \\
\text { as } \mathrm{SO}_{4} \text { ) a }\end{array}$ \\
\hline
\end{tabular}

North Fork

Quitchupah Creek SW-2 08-01-79 540

North Fork

Quitchupan Creek SH-5 10-24-86 680

South Fork

Quitchupah Creek SW-11 $10-24-86 \quad 720$

South Fork

Quitchupah Creek

South Fork

Quitchupan creek

North Fork

Quitchupan creek

North Fork

Quitchupah creek

North Fork

Quitchupah Creek

Quitchupah Creek

East Spring Canyon

East Spring Canyon

Quitchupah Creek

Quitchupah Creek

Quitchupah Creek

Qui tchupah Creek

Quitchupah Creek

Muddy Creek

Muddy Creek near

Emery, Utah

Station 09330500
$08-21-80 \quad 540$

09-18-80 570L

SW-16 08-08-79 490

SH-21 09-18-80 660L

$\begin{array}{lll}8.6 & 12.0 \quad 120\end{array}$

$10-23-86 \quad 710$

05-13-87 680

SH-23 09-18-80 1,400

SH-24 05-10-79, 175

SH-25 $\quad 09-17-80 \quad 900$

SH-26 $\quad 09-17-801,050$

SW-27 10-22-80 880

11-19-80 800

05-24-81 710

06-28-81 680

07-15-81 680

08-14-81 700

09-04-81 690

09-07-81 680

05-19-82 910

07-14-82 1,050

$06-07-83 \quad 890$

08-04-83 1,140

07-20-84 1,330

09-06-84 1,300

SW-28 $\quad 09-27-76 \quad 800$

SH-20 09-09-78 790

08-05-79 730

08-18-80 670

09-17-80 970

SH-30 05-15-80 850

09-17-80 1,280

SW-35 08-16-79 395

05-16-80 460

08-20-80 460

09-17-80 430

-- 10-23-86 440
$8.1 \quad 19.5 \quad 13$

$\begin{array}{lrr}8.7 & 7.5 & 0 \\ 8.5 & 14.5 & 0\end{array}$

$8.6 \quad 1.5 \quad 0$

$8.4 \quad 1.5 \quad 1$

$8.1 \quad 15.0 \quad 71$

$\begin{array}{lll}8.7 & 6.5 \quad 39\end{array}$

$8.5 \quad 19.0 \quad 50$

$8.7 \quad 6.5 \quad 39$

$8.5 \quad 15.0 \quad 68$

$\begin{array}{lll}8.4 & 13.0 \quad 68\end{array}$

$8.7 \quad 6.5 \quad 270$

$\begin{array}{lll}7.5 & 2.0 \quad 15\end{array}$

$8.213 .5 \quad 100$

$8.2 \quad 11.5 \quad 150$

$8.2 \quad 10.0 \quad 150$

$8.2 \quad 9.0 \quad 95$

$8.4 \quad 12.5 \quad 100$

$8.5 \quad 16.0 \quad 96$

180

240

289

300

$8.4 \quad 15.0 \quad 100$

$8.4 \quad 14.0 \quad 88$

$\begin{array}{lll}8.6 & 14.5 & 0\end{array}$

$\begin{array}{rrr}8.4 & 14.0 & 93\end{array}$

$8.2 \quad 16.0$

8.410 .5

$8.4 \quad 4.5$

8.114 .5

8.214 .5

$8.3 \quad 13.5 \quad 92$

$8.6 \quad 14.0 \quad 91$

$8.5 \quad 15.0 \quad 150$

$8.5 \quad 17.0 \quad 87$

$\begin{array}{lll}8.5 & 8.0 \quad 99\end{array}$

$\begin{array}{lll}7.8 & 12.0 & 81\end{array}$

$\begin{array}{lll}8.5 & 12.5 & 47\end{array}$

$8.614 .5 \quad 16$

$8.8 \quad 8.5 \quad 0$

$8.7 \quad 10.5 \quad 3$

$8.5 \quad 12.0 \quad 11$

8.7

210

230

160

230

230

217

215

350

200

300

320

330

240

240

220

230

$\ddot{200}$

220

265

280

240

200

260

210

290

190

230

190

190

$\begin{array}{lll}6.5 & 2 & 21\end{array}$

$\begin{array}{rrr}840 & -- & 41 \\ 320 & -- & 51 \\ 340 & -- & 49 \\ 400 & 348 & 64\end{array}$

450

454

$<330$

-. $\quad$ - $\quad 718$

$\begin{array}{lll}-- & -- & 527\end{array}$

-- $\quad--\quad 747$

$\begin{array}{lll}-- & -- & 858 \\ -- & -- & 796\end{array}$

- 58

$\begin{array}{lll}370 \quad-\quad & 55\end{array}$

$880 \quad--\quad 38$

$400 \quad--\quad 50$

$450 \quad--\quad 55$

530

370

830

470

550

580

540

440

$420 \quad 344$

430

410

410

420

520

510

420

540

420

680

810

260

210

$210 \quad \ldots \quad 41$

$\begin{array}{ll}-- & 72 \\ -- & 74 \\ -- & 55 \\ -- & 52 \\ -- & 63 \\ & 59 \\ -- & 59 \\ -- & 54 \\ -- & 43 \\ -- & 49\end{array}$

250

$245 \quad 45$
24

28

$\begin{array}{ll}22 & 1.0 \\ 35 & 1.1 \\ 44 & 1.9\end{array}$

28

6430

$44 \quad 1.7$

53

63

35

$50 \quad 2.3$

92

33

$\begin{array}{ll}4.8 & 1.7\end{array}$

93

$\begin{array}{llll}32 & 27 & 1.7 & 92\end{array}$

$\begin{array}{llll}28 & 22 & 1.4 & 76\end{array}$

$\begin{array}{llll}35 & 38 & 1.9 & 110\end{array}$

$\begin{array}{llll}39 & 48 & 2.2 & 140\end{array}$

$\begin{array}{llll}41 & 50 & 2.7 & 210\end{array}$

$\begin{array}{rrrr}29 & 33 & 1.8 & 91 \\ 92 & 52 & 5.1 & 330\end{array}$

$\begin{array}{llll}7.2 & 3.9 & 4.3 & 13\end{array}$

$\begin{array}{llll}45 & 21 & 3.3 & 110\end{array}$

$\begin{array}{llll}59 & 29 & 3.9 & 160\end{array}$

$\begin{array}{llll}58 & 30 & 3.8 & 170\end{array}$

$\begin{array}{llll}51 & 25 & 3.7 & 140 \\ 41 & 23 & 2.6 & 130\end{array}$

$\begin{array}{llll}41 & 23 & 2.1 & 130\end{array}$

$\begin{array}{llll}0 & 25 & 2.5 & 130\end{array}$

$\begin{array}{llll}39 & 25 & 2.5 & 130\end{array}$

$\begin{array}{llll}38 & 27 & 2.0 & 150\end{array}$

$\begin{array}{llll}39 & 23 & 2.8 & 120 \\ 57 & 31 & 3.5 & 180\end{array}$

$\begin{array}{llll}65 & 45 & 3.6 & 280\end{array}$

$\begin{array}{llll}41 & 45 & 6.6 & 100\end{array}$

$\begin{array}{llll}70 & 51 & 4.2 & 210\end{array}$

$\begin{array}{llll}88 & 48 & 4.8 & 240\end{array}$

$\begin{array}{llll}90 & 49 & 5.3 & 220\end{array}$

$\begin{array}{llll}43 & 19 & 2.6 & 99\end{array}$

$\begin{array}{llll}45 & 34 & 3.5 & 140\end{array}$

$\begin{array}{lll}61 & 32 & 12\end{array}$

$\begin{array}{lll}38 & 31 & 2.7\end{array}$

170

$49 \quad 3.2 \quad 180$

$\begin{array}{llll}35 & 38 & 3.0 & 120\end{array}$

$\begin{array}{rrr}38 & 3.0 & 120 \\ 110 & 3.1 & 240\end{array}$

$6.4 \quad 0.90$

$22 \quad 1.5$

7.40 .60

17

$10 \quad 1.0$

14

$\begin{array}{lll}27 & 14 & 1.2\end{array}$

2 
10- Silica,

dis- Arsenic, Barium, Bery7

Chro-

Manga- Molyb- Sele- Stron- Vana-

solved dis- dis- lium, Boron, Cadmium, solved solved solved solved solved $(\mu \mathrm{g} / \mathrm{L}$ $(\mu \mathrm{g} / \mathrm{L} \quad \mu \mathrm{g} / \mathrm{L}(\mu \mathrm{g} / \mathrm{L}(\mu \mathrm{g} / \mathrm{L}$ as As) as Ba) as Be) as B) as (d) mium, Cobalt, Copper, Iron, Lead, Lithium, nese, denum, nium, tium, dium, Zinc, dis- dis- dis- dis- dis- dis- dis- dis- dis- dis- dis- dissolved solved solved solved solved solved solved solved solved solved solved solved

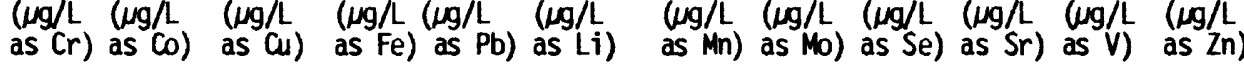

Mn) as Mo) as Se) as Sr) as V) as Zn
Sil
30

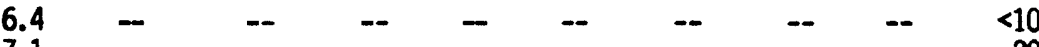

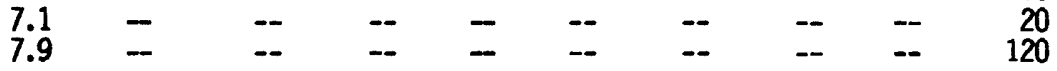

8.0

7.7

7.2

8.0

7.1

7.7

8.2

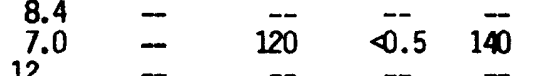

$\begin{array}{ccccc}12 & - & -- & -- & - \\ 6.3 & - & - & -- & -\end{array}$

13

$\begin{array}{rrrr}-- & -- & -- & - \\ -- & \overline{3} & -- & - \\ 1 & 80 & <1 & 150 \\ - & 90 & <1 & 190 \\ -- & -- & -\end{array}$

--
$-\overline{1}$
$<1$

$\overline{0}$

-- $\quad \overline{1} \quad 3 \overline{10}$

$\begin{array}{lll}-- & -- & - \\ -- & \overline{1} & \overline{10}\end{array}$

$\overline{--} \quad \overline{10}$

$\overline{--} \quad \overline{-}$

$$
-
$$

15

14

$\begin{array}{ll}-- & - \\ -- & -\end{array}$

$<10$
4

10

12

61

20

70

20

30

40

20

.30

3011

2011

$.20 \quad 12$

$\overline{<1} \quad--\overline{0} \quad \overline{0.8} \quad \overline{100}$

$\begin{array}{llll}\overline{<1} & -- & -- & \overline{180} \\ <1 & \overline{71} & <1 & 180\end{array}$

--
$<1$
$-\overline{<}$
$<1$

$\begin{array}{rrr}<- & -- & -- \\ <10 & -- & 2 \\ <- & -- & -- \\ <10 & -- & 2 \\ & -- & <1\end{array}$

$\begin{array}{lll}-- & -- & 120 \\ -- & -- & 130 \\ -- & -- & 300\end{array}$

$\begin{array}{lll}- & - & 300 \\ -- & - & 250\end{array}$

--

ND

$--\quad--\quad<10$

$\begin{array}{cc}10 & <1 \\ 12 & 1 \\ 9.1 & 1 \\ 10 & 1 \\ 11 & -\end{array}$

30

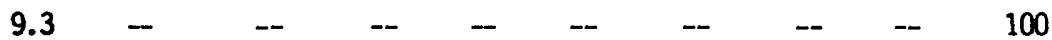

$\begin{array}{llll}\text { ND } & -- & -- & <10 \\ \text { ND } & -- & -- & <10\end{array}$

$--\quad--\quad<10$

$\begin{array}{rrr}6 & -\overline{0} & -- \\ 18 & <10 & 25 \\ 30 & -- & -- \\ 18 & <- & --\end{array}$

5.8

6.3

$--$

5.8

$\begin{array}{rrr}6 & -\overline{1} & -- \\ 4 & <10 & 1 \\ 8 & -- & -- \\ <10 & -- & --\end{array}$

$\begin{array}{ccc}930 & -\overline{6} & \overline{14} \\ -- & -- & - \\ -\overline{550} & -\overline{3} & \overline{6}\end{array}$

6.3

-

$-$ 


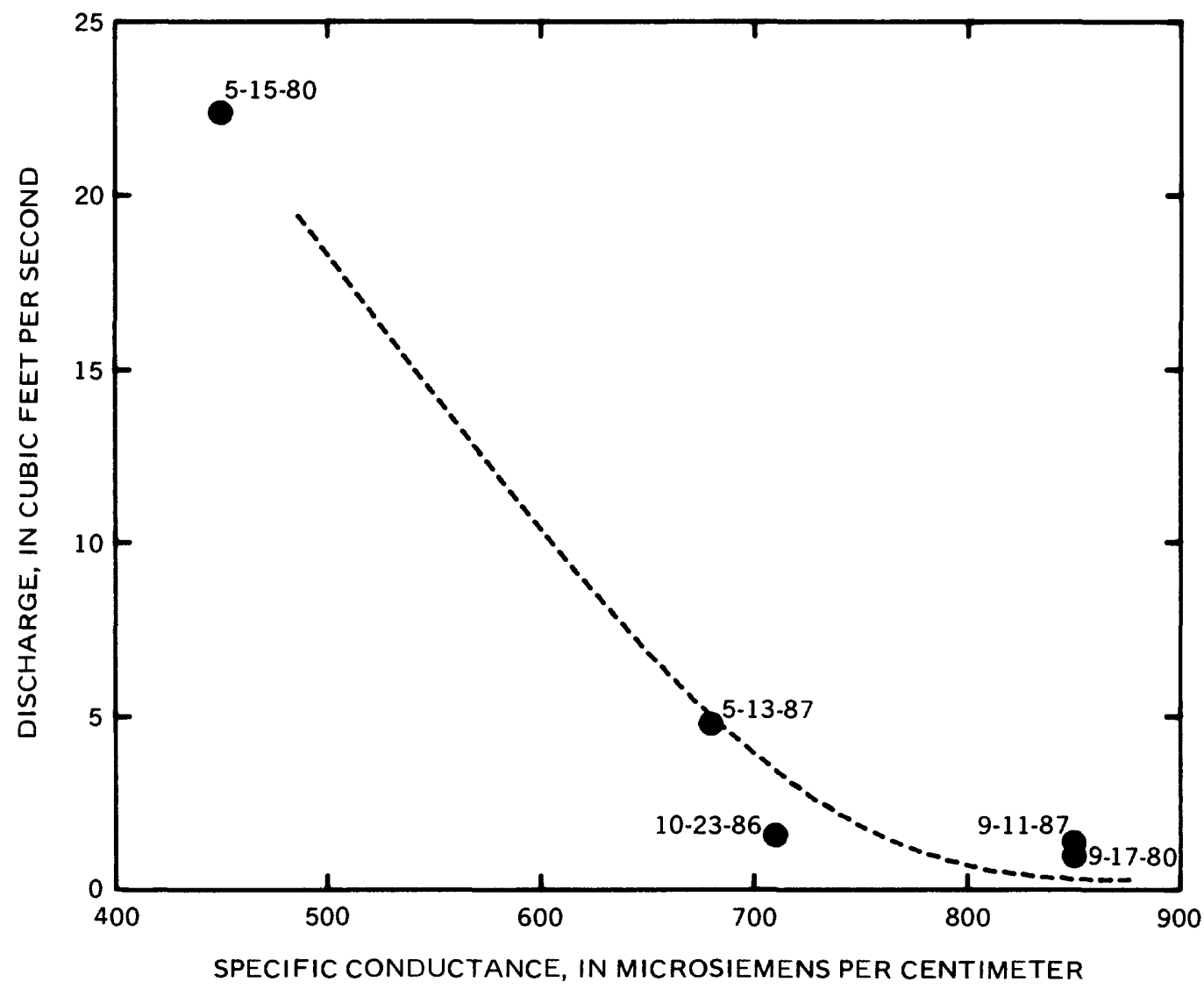

Figure 10.--Relation between specific conductance and discharge at North Fork Quitchupah Creek (site SW-22).

An estimate of the source-area sediment yield from the study area was obtained using a modification of the Pacific Southwest Inter-Agency Committee (PSIAC) method (Frickel and others, 1975). The method is based on a sumation of numerical ratings for certain erosion-related factors. Estimated annual source-area sediment yield calculated for the study area using the PSIAC method is about 0.5 acre-ft $/ \mathrm{mi}^{2}$. Based on a map by the U.S. Department of Agriculture (1973), Waddell and others (1981, pl.6) estimated annual sediment yield for the general area to range from 0.1 to $1.0 \mathrm{acre}-\mathrm{ft} / \mathrm{mi}^{2}$. Insufficient sediment data were obtained within the study area to verify the estimated sediment yields.

\section{GROUND-WATER HYDROLOGY}

Data collected from springs, coal-exploration holes, and the SUFCo mine indicate that the ground-water system in the Quitchupah and Pines study area is similar to that of the rest of the Wasatch Plateau coal field. Water is present in all of the geologic units exposed at land surface as either continuous or discontinuous saturated zones. Water movement in the saturated zones is controlled mainly by fractures, dip of the units, and hydraulic conductivity of the rocks. 


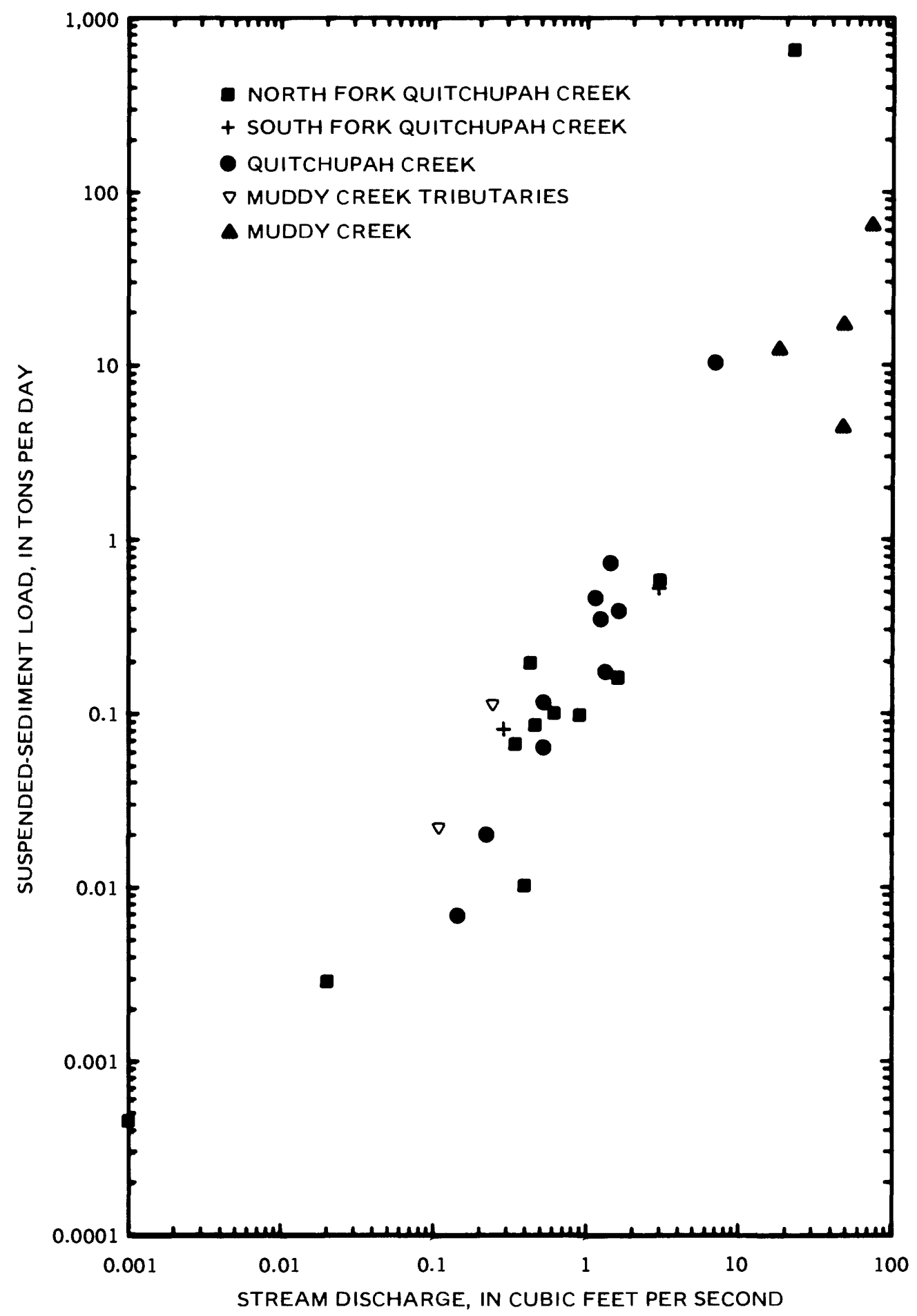

Figure 11.--General relation of stream discharge to suspendedsediment load for streams draining the study area. 


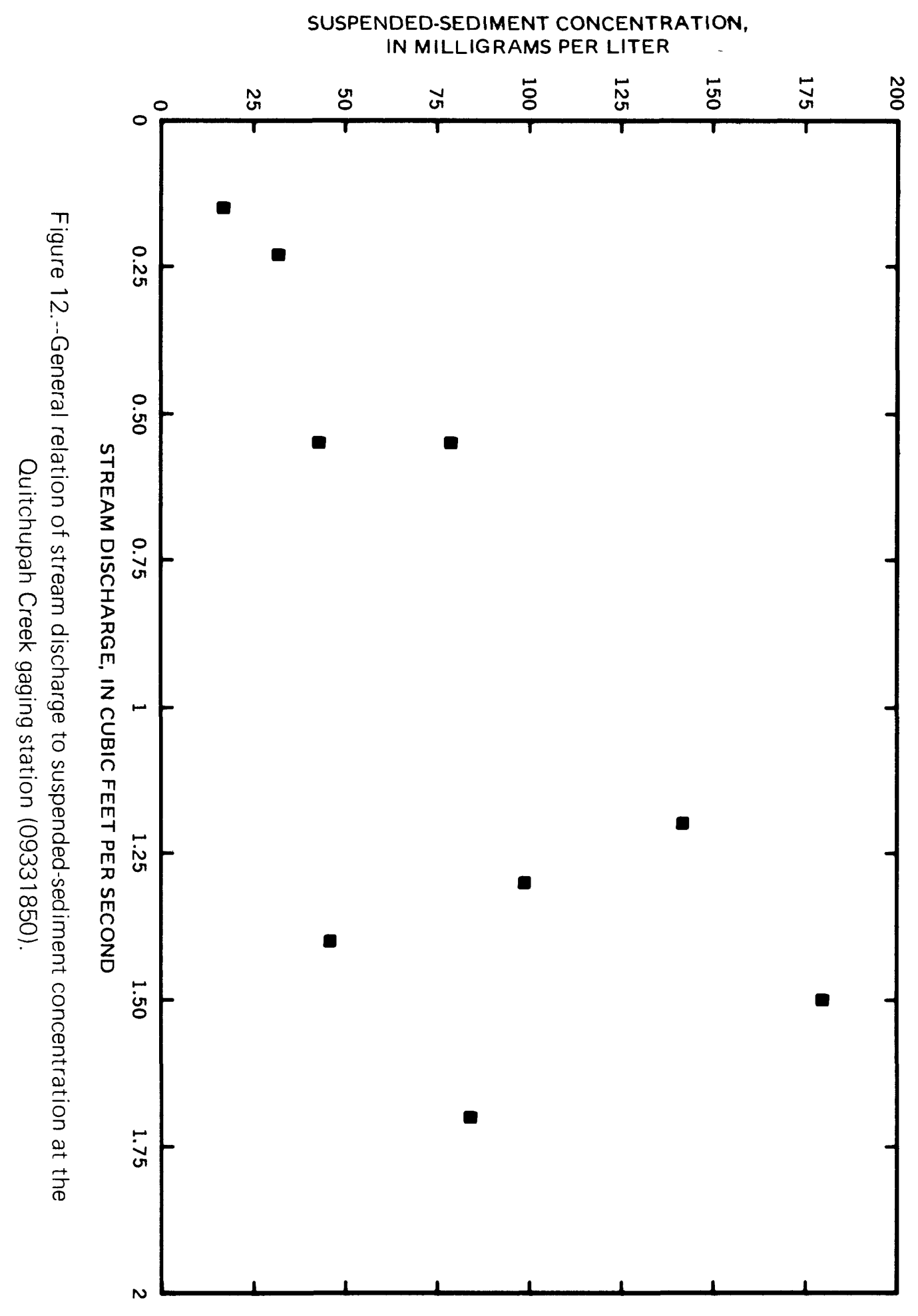




\section{General Oocurrence, Recharge, and Discharge}

Formations exposed in the study area that contain ground water include, fram oldest to youngest, the Masuk Member of the Manoos Shale, the Star Point Sandstone, the Blackhawk Formation, the Castlegate Sandstone, the Price River Formation, the North Horn Formation, and unconsolidated alluvial deposits. The Masuk Member contains ground water in thin, discontinuous lenses of limestone and sandstone, but overall it is considered a confining layer because it consists of a large thickness of virtually impermeable shale. The Flagstaff Limestone, which overlies the North Horn Formation outside the study area to the west, is important because recharge to older formations typically occurs through the Flagstaff Limestone by vertical movement through fractures and faults.

Stable-isotope studies indicate that recharge to the ground-water system is principally by snowmelt seeping into outcrops. Concentrations of deuterium in samples of water fram rain, snow, springs, and mines collected from the upper drainages of Huntington and Cottonwood Creeks (Danielson and others, 1981), about 20 miles north of the study area, were similar in ground water and melted snow but were appreciably less in rain water.

Discharge from the ground-water system occurs at springs, seeps, mines, and at zones of seepage in streambeds. Most of the springs inventoried during this study discharge at or near formation contacts as a result of contrasting hydraulic conductivity between adjacent rock types. Other springs are controlled by faults and fractures within the formations or by isolated lenses of finer grained rock with a substantially smaller hydraulic conductivity than that of the principal aquifer material. Discharge quantities and selected properties of the water from springs and mine inflows are summarized in table 5.

Discharge rates from springs in $1986 \mathrm{ranged}$ fram $6.0 \mathrm{gal} / \mathrm{min}$ from the Price River Formation at Lizonbee Springs, (D-21-4) $34 \mathrm{bcd}-\mathrm{Sl}$, to $0.4 \mathrm{gal} / \mathrm{min}$ from the Castlegate Sandstone at (D-22-5)7aca-Sl. All of the springs inventoried were perennial with the exception of the springs and seeps near the top of Duncan Draw. As the summer of 1986 progressed and water levels dropped, the Duncan Draw springs discharged at progressively lower altitudes.

Inflow to and seepage from North Fork Quitchupah Creek was measured in September 1987 to document base flow and recharge or discharge from seepage. Measuring sites were at or near formation contacts and at surface-water inflows. The South Fork Quitchupah Creek and the SUFCo mine portal were the only sources contributing surface flows.

The investigation indicated an apparent gain in flow from ground-water discharge where the North Fork Quitchupah Creek crossed the Castlegate Sandstone, a loss of flow as it crossed the upper part of the Blackhawk Formation, a considerable gain in flow crossing the Star Point Sandstone, and a loss of flow crossing the Mancos Shale (fig. 13). 
Table 5.--Discharge, temperature, and specific conductance

of water from selected springs and mines

[gal/min, gallons per minute; ${ }^{\circ} \mathrm{C}$, degrees Celsius; $\mu S / \mathrm{cm}$, microsienens per cent imeter at 25 degrees Celsius]

Location: See page 5 for an explanation of the numbering system for ground-water sites. Mine sites are projected to land surface.

Altitude: Given in feet above National Geodetic Vertical Datum of 1929.

Geologic unit: Formation from which spring or mine is discharging: Kbh, Blackhask formation; Kc, Castlegate Sandstone; Kpr, Price River Formation: TKnh, North Horn Formation; Qa, al luvium.

Discharge: Measured with a current meter or at a gaging station except where noted e (estimated).

Specific conductance: Measured in field except where noted $L$ (laboratory value). Dashes (--) indicate no data.

Other data available: C, chemical analyses in table 6; T, trace element analyses in table 6.

\begin{tabular}{|c|c|c|c|c|c|c|c|c|c|}
\hline Location & $\begin{array}{l}\text { Site number } \\
\text { (see pl. 1) }\end{array}$ & $\begin{array}{l}\text { Name of spring } \\
\text { or mine }\end{array}$ & $\begin{array}{l}\text { Altitude } \\
\text { (feet) }\end{array}$ & $\begin{array}{c}\text { Geologic } \\
\text { unit }\end{array}$ & Date & $\begin{array}{l}\text { Dis- } \\
\text { charge } \\
\text { (gal/min) }\end{array}$ & $\begin{array}{l}\text { Water } \\
\text { temper- } \\
\text { ature } \\
\left({ }^{\circ} \mathrm{C}\right)\end{array}$ & $\begin{array}{l}\text { Spe- } \\
\text { cific } \\
\text { con- } \\
\text { duct- } \\
\text { ance } \\
\text { (1S/cm) }\end{array}$ & $\begin{array}{l}\text { Other } \\
\text { data } \\
\text { available }\end{array}$ \\
\hline \multirow[t]{2}{*}{$(D-20-5) 31 a b d-S 1$} & $G W-1$ & -- & 8,390 & Kpr & $\begin{array}{l}09-25-76 \\
08-09-79 \\
07-15-86 \\
08-04-86 \\
08-20-86\end{array}$ & $\begin{array}{l}1.0 \\
1.5 \\
1.5 \\
0.9 \\
1.5\end{array}$ & $\begin{array}{r}-- \\
12.0 \\
6.5 \\
9.0 \\
7.5\end{array}$ & $\begin{array}{l}720 \\
750 \mathrm{~L} \\
700 \\
810 \\
860\end{array}$ & C \\
\hline & & & & & $\begin{array}{l}09-18-86 \\
11-04-86 \\
05-11-87 \\
06-16-87 \\
07-20-87\end{array}$ & $\begin{array}{l}0.9 \\
1.4 \\
1.6 \\
1.5 \\
3.0\end{array}$ & $\begin{array}{l}7.5 \\
5.0 \\
5.0 \\
8.0 \\
7.0\end{array}$ & $\begin{array}{l}840 \\
840 \\
850 \\
860 \\
860\end{array}$ & \\
\hline$(0-20-5) 32 b b c-S 1$ & GW-2 & -- & 8,280 & Kpr & $\begin{array}{l}09-08-87 \\
09-25-76\end{array}$ & $\begin{array}{l}4.0 \\
0.2\end{array}$ & $\begin{array}{r}9.0 \\
13.0\end{array}$ & 860 & $C, T$ \\
\hline$(D-20-5) 33 c c c-S 1$ & GN-3 & -- & 8,160 & $\mathrm{Kpr}$ & $\begin{array}{l}08-20-86 \\
09-15-86\end{array}$ & $\begin{array}{l}3.0 \\
2.3\end{array}$ & $\begin{array}{l}9.5 \\
9.0\end{array}$ & $\begin{array}{r}1,130 \\
940\end{array}$ & C \\
\hline $\begin{array}{l}(D-21-4) 22 b d b-S 1 \\
(D-21-4) 26 b a b-S 1 \\
0-21-4) 26 b d a-S 1\end{array}$ & $\begin{array}{l}E N-5 \\
G N-6\end{array}$ & -- & $\begin{array}{l}8,850 \\
8,780\end{array}$ & $\begin{array}{l}\text { Kpr } \\
\text { TKnh } \\
\text { TKnh }\end{array}$ & $\begin{array}{l}09-17-76 \\
07-01-79 \\
08-05-86 \\
07-24-78 \\
08-19-86\end{array}$ & $\begin{array}{l}1.5 \\
0.8 \\
4.9 \\
0.1 \\
1.6\end{array}$ & $\begin{array}{r}8.0 \\
12.0 \\
6.0 \\
17.0 \\
10.5\end{array}$ & $\begin{array}{r}1,200 \\
540 \\
640 \\
540 \\
1,800\end{array}$ & $C, T$ \\
\hline \multirow[t]{2}{*}{$\left(\begin{array}{l}D-21-4 \\
D-21-4\end{array}\right) 34 b c d-S 1$} & $\begin{array}{l}G N-7 \\
G N-8\end{array}$ & Lizonbee Springs & $\begin{array}{l}8,740 \\
8,160\end{array}$ & $\underset{K p r}{\text { Knnh }}$ & $\begin{array}{l}09-03-86 \\
06-30-79 \\
09-16-76 \\
07-01-79 \\
09-27-79\end{array}$ & $\begin{array}{l}0.5 \\
2 . \overline{8} \\
2.0 \\
1.0\end{array}$ & $\begin{array}{r}12.5 \\
7.0 \\
10.0 \\
7.0 \\
10.0\end{array}$ & $\begin{array}{l}1,830 \\
1,150 \\
1,210 \\
1,100 \\
1,220 \mathrm{~L}\end{array}$ & $C, T$ \\
\hline & & & & & $\begin{array}{l}06-30-80 \\
07-23-80 \\
08-06-80 \\
08-21-80 \\
09-05-80\end{array}$ & $\begin{array}{l}4.4 \\
3.4 \\
2.7 \\
2.5 \\
2.4\end{array}$ & $\begin{array}{l}7.5 \\
7.5 \\
8.0 \\
8.0 \\
7.5\end{array}$ & $\begin{array}{l}1, \overline{200} \\
1,210 \\
1,220 \\
1,370\end{array}$ & \\
\hline$(D-21-4) 34 b c d-S 2$ & GN-9 & Lizonbee Springs & 8,155 & Kpr & $\begin{array}{l}09-16-80 \\
09-29-80 \\
09-17-86 \\
08-05-86 \\
09-17-86\end{array}$ & $\begin{array}{l}3.0 \\
3.3 \\
6.0 \\
1.9 \\
1.9\end{array}$ & $\begin{array}{l}8.0 \\
8.0 \\
7.0 \\
7.5 \\
7.5\end{array}$ & $\begin{array}{l}1,550 \\
1,440 \\
1,340 \\
1,170 \\
1,220\end{array}$ & C \\
\hline \multirow[t]{2}{*}{$\begin{array}{l}(D-21-4) 36 c c c \\
(D-21-4) 36 c b b \\
D-21-4) 36 d d c-S 1\end{array}$} & $\begin{array}{l}\text { GN-10 } \\
G_{N}-11 \\
G_{N}-12\end{array}$ & $\begin{array}{l}\text { SUFCo mine } \\
\text { SUFCo mine } \\
\text { East Spring }\end{array}$ & $\overline{--}$ & $\begin{array}{l}\mathrm{Kbh} \\
\mathrm{Kbh} \\
\mathrm{KC}\end{array}$ & $\begin{array}{l}07-23-80 \\
07-23-80 \\
07-30-80 \\
08-05-80 \\
08-21-80\end{array}$ & $\begin{array}{r}-- \\
2 . \overline{9} \\
3.0 \\
2.7\end{array}$ & $\begin{array}{r}10.0 \\
9.0 \\
6.5 \\
6.0 \\
6.5\end{array}$ & $\begin{array}{l}680 \\
540 \\
440 \\
425 \\
435\end{array}$ & $\begin{array}{l}c \\
C \\
C, T\end{array}$ \\
\hline & & & & & $\begin{array}{l}09-05-80 \\
09-16-80 \\
09-29-80 \\
08-22-86 \\
09-18-86 \\
10-10-86\end{array}$ & $\begin{array}{c}2.3 \\
2.6 \\
2.6 \\
4.4 \\
4.0 \\
-\end{array}$ & $\begin{array}{l}6.5 \\
6.5 \\
6.5 \\
6.5 \\
7.0 \\
7.0\end{array}$ & $\begin{array}{l}455 \\
-5 \\
500 \\
470 \\
460 \\
450\end{array}$ & \\
\hline
\end{tabular}


Table 5.--Discharge, temperature, and specific conductance of water from selected springs and mines-continued

\begin{tabular}{|c|c|c|c|c|c|c|c|c|c|}
\hline Location & $\begin{array}{l}\text { Site numbe } \\
\text { (see pl. } 1\end{array}$ & $\begin{array}{l}\text { Name of spring } \\
\text { or mine }\end{array}$ & $\begin{array}{l}\text { Altitude } \\
\text { (feet) }\end{array}$ & $\begin{array}{c}\text { Geologic } \\
\text { unit }\end{array}$ & Date & $\begin{array}{l}\text { Dis- } \\
\text { charge } \\
\text { (gal/min) }\end{array}$ & $\begin{array}{l}\text { Water } \\
\text { temper- } \\
\text { ature } \\
\left({ }^{\circ} \mathrm{C}\right)\end{array}$ & $\begin{array}{c}\text { Spe- } \\
\text { cific } \\
\text { con- } \\
\text { duct- } \\
\text { ance } \\
(\mu S / \mathrm{cm})\end{array}$ & $\begin{array}{l}\text { Other } \\
\text { data } \\
\text { available }\end{array}$ \\
\hline $\begin{array}{l}(D-21-4) 36 d d c-S 1 \\
(D-21-5) \text { 8aaa-S1 }\end{array}$ & $\begin{array}{l}\text { GN-12 } \\
\text { GW-13 }\end{array}$ & -- & 8,600 & TKnh & $\begin{array}{l}05-12-87 \\
06-16-87 \\
07-20-87 \\
09-09-87 \\
09-18-86\end{array}$ & $\begin{array}{l}4.3 \\
3.8 \\
3.4 \\
3.2 \\
2.6\end{array}$ & $\begin{array}{l}6.0 \\
6.0 \\
6.5 \\
7.0 \\
7.0\end{array}$ & $\begin{array}{l}450 \\
500 \\
480 \\
480 \\
800\end{array}$ & C \\
\hline 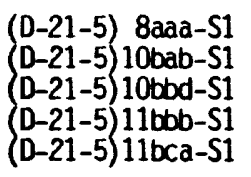 & $\begin{array}{l}G N-13 \\
G N-14 \\
G N-15 \\
G N-16 \\
G N-17\end{array}$ & $\begin{array}{l}-- \\
-- \\
-- \\
--\end{array}$ & $\begin{array}{l}8,600 \\
8,000 \\
8,000 \\
8,000 \\
8,200\end{array}$ & $\begin{array}{l}7 \mathrm{Knh} \\
\mathrm{Kbh} \\
\mathrm{KC}_{\mathrm{C}} \\
\mathrm{KC}_{\mathrm{C}} \\
\mathrm{KC}\end{array}$ & $\begin{array}{l}11-04-86 \\
09-16-86 \\
09-16-86 \\
09-19-86 \\
09-19-86\end{array}$ & $\begin{array}{l}2.4 \\
0.6 \\
5.1 \\
3.6 \\
2.0\end{array}$ & $\begin{array}{l}6.0 \\
7.5 \\
6.5 \\
4.0 \\
7.0\end{array}$ & $\begin{array}{l}800 \\
310 \\
215 \\
320 \\
290\end{array}$ & $\begin{array}{l}c \\
C \\
C \\
C\end{array}$ \\
\hline $\begin{array}{l}(D-21-5) 11 b d c-S 1 \\
(D-21-5) 14 b a a-S 1 \\
(D-21-5) 15 b c d-S 1\end{array}$ & $\begin{array}{l}\text { GW-18 } \\
\text { GW-19 } \\
\text { GW-20 }\end{array}$ & -- & $\begin{array}{l}8,280 \\
8,360 \\
8,260\end{array}$ & $\begin{array}{l}K_{C} \\
K_{C}\end{array}$ & $\begin{array}{l}09-19-86 \\
08-19-86 \\
09-15-86 \\
11-04-86 \\
09-16-86\end{array}$ & $\begin{array}{l}0.7 \\
0.5 \\
0.8 \\
0.9 \\
1.6\end{array}$ & $\begin{array}{l}5.5 \\
9.0 \\
7.5 \\
4.0 \\
7.0\end{array}$ & $\begin{array}{l}345 \\
105 \\
-- \\
95 \\
215\end{array}$ & $\begin{array}{l}c \\
c\end{array}$ \\
\hline \multirow[t]{4}{*}{$(D-21-5) 26$ bab-S1 } & GW-21 & -- & 8,480 & $\mathrm{KC}$ & $\begin{array}{l}06-30-79 \\
08-11-79 \\
06-30-80 \\
07-23-80\end{array}$ & $\begin{array}{l}0.3 \\
0.2 \\
0.4 \\
0.3\end{array}$ & $\begin{array}{l}8.0 \\
7.0 \\
5.5 \\
6.0\end{array}$ & $\begin{array}{l}320 \\
260 \\
290 \\
275\end{array}$ & c \\
\hline & & & & & $\begin{array}{l}08-05-80 \\
08-21-80 \\
09-11-80 \\
09-16-80 \\
09-29-80\end{array}$ & $\begin{array}{l}0.2 \\
0.2 \\
0.2 \\
0.2 \\
0.3\end{array}$ & $\begin{array}{l}6.5 \\
6.0 \\
6.5 \\
6.0 \\
6.0\end{array}$ & $\begin{array}{l}260 \\
265 \\
275 \\
280 \\
300\end{array}$ & \\
\hline & & & & & $\begin{array}{l}07-15-86 \\
08-04-86 \\
08-20-86 \\
09-15-86 \\
11-04-86\end{array}$ & $\begin{array}{l}0.7 \\
0.6 \\
0.6 \\
0.7 \\
0.9\end{array}$ & $\begin{array}{l}6.5 \\
7.0 \\
7.0 \\
7.5 \\
6.0\end{array}$ & $\begin{array}{l}300 \\
295 \\
315 \\
300 \\
300\end{array}$ & \\
\hline & GW-22 & Link Canyon Mine & 7,680 & $\mathrm{Kbh}$ & $\begin{array}{l}05-11-87 \\
06-16-87 \\
07-20-87 \\
09-08-87 \\
07-15-86\end{array}$ & $\begin{array}{l}1.1 \\
0.9 \\
0.7 \\
0.6 \\
-\end{array}$ & $\begin{array}{r}5.0 \\
5.5 \\
6.5 \\
7.0 \\
14.5\end{array}$ & $\begin{array}{l}310 \\
310 \\
310 \\
310 \\
800\end{array}$ & C \\
\hline \multirow{2}{*}{$(D-21-5) 26 b c d$} & & & & & $\begin{array}{l}08-04-86 \\
08-20-86 \\
09-15-86 \\
11-04-86 \\
05-11-87\end{array}$ & $\begin{array}{l}1.5 \\
2.2 \\
1.6 \\
1.3 \\
2.0\end{array}$ & $\begin{array}{l}14.5 \\
14.0 \\
14.0 \\
14.0 \\
13.5\end{array}$ & $\begin{array}{l}790 \\
820 \\
790 \\
800 \\
820\end{array}$ & \\
\hline & $\begin{array}{l}G W-23 \\
G W-24\end{array}$ & SUFCo mine portal & $\begin{array}{l}7,420 \\
7,400\end{array}$ & $\begin{array}{l}\mathrm{Kbh} \\
\mathrm{Kbh}\end{array}$ & $\begin{array}{l}06-16-87 \\
07-20-87 \\
09-08-87 \\
09-10-87 \\
10-10-86\end{array}$ & $\begin{array}{l}1.5 \\
1.7 \\
1.6 \\
3 \mathrm{e} \\
923\end{array}$ & $\begin{array}{l}14.0 \\
14.0 \\
14.5 \\
10.0 \\
12.0\end{array}$ & $\begin{array}{r}830 \\
820 \\
820 \\
1,000 \\
860\end{array}$ & C \\
\hline 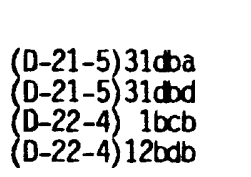 & $\begin{array}{ll}G W-25 & S \\
\text { GW-26 } \\
\text { GW-27 } \\
\text { GW-28 }\end{array}$ & $\begin{array}{l}\text { SUFCo mine } \\
\text { SUFCo mine } \\
\text { SUFCo mine } \\
\text { SUFCo mine portal }\end{array}$ & $\begin{array}{l}-- \\
-- \\
7,580\end{array}$ & $\begin{array}{l}\mathrm{Kbh} \\
\mathrm{Kbh} \\
\mathrm{Kbh} \\
\mathrm{Kbh}\end{array}$ & $\begin{array}{l}09-10-87 \\
10-10-86 \\
07-23-80 \\
05-02-79 \\
09-27-76\end{array}$ & $\begin{array}{r}461 \\
0.4 \\
2.3 \\
224\end{array}$ & $\begin{array}{l}12.5 \\
10.5 \\
11.0 \\
11.0 \\
10.0\end{array}$ & $\begin{array}{l}980 \\
600 \\
530 \\
680 \\
475\end{array}$ & $\begin{array}{l}C, T \\
C \\
C \\
C, T\end{array}$ \\
\hline $\begin{array}{ll}(0-22-5) & 6 \mathrm{dbc} \\
(0-22-5) & 7 \mathrm{cca}-S 1\end{array}$ & $\begin{array}{l}G W-29 \\
G W-30\end{array}$ & SUFCo mine & $8, \overline{-} 450$ & $\begin{array}{l}\mathrm{Kbh} \\
\mathrm{KC}\end{array}$ & $\begin{array}{l}09-01-78 \\
05-02-79 \\
08-06-86 \\
09-18-86 \\
05-12-87 \\
09-09-87\end{array}$ & $\begin{array}{r}240 \\
- \\
0.5 \\
0.4 \\
0.5 \\
1.5\end{array}$ & $\begin{array}{r}11.0 \\
12.0 \\
7.5 \\
8.0 \\
4.0 \\
7.0\end{array}$ & $\begin{array}{l}640 \\
590 \\
96 \\
95 \\
98 \\
97\end{array}$ & $\begin{array}{l}\mathrm{C} \\
\mathrm{C}\end{array}$ \\
\hline
\end{tabular}




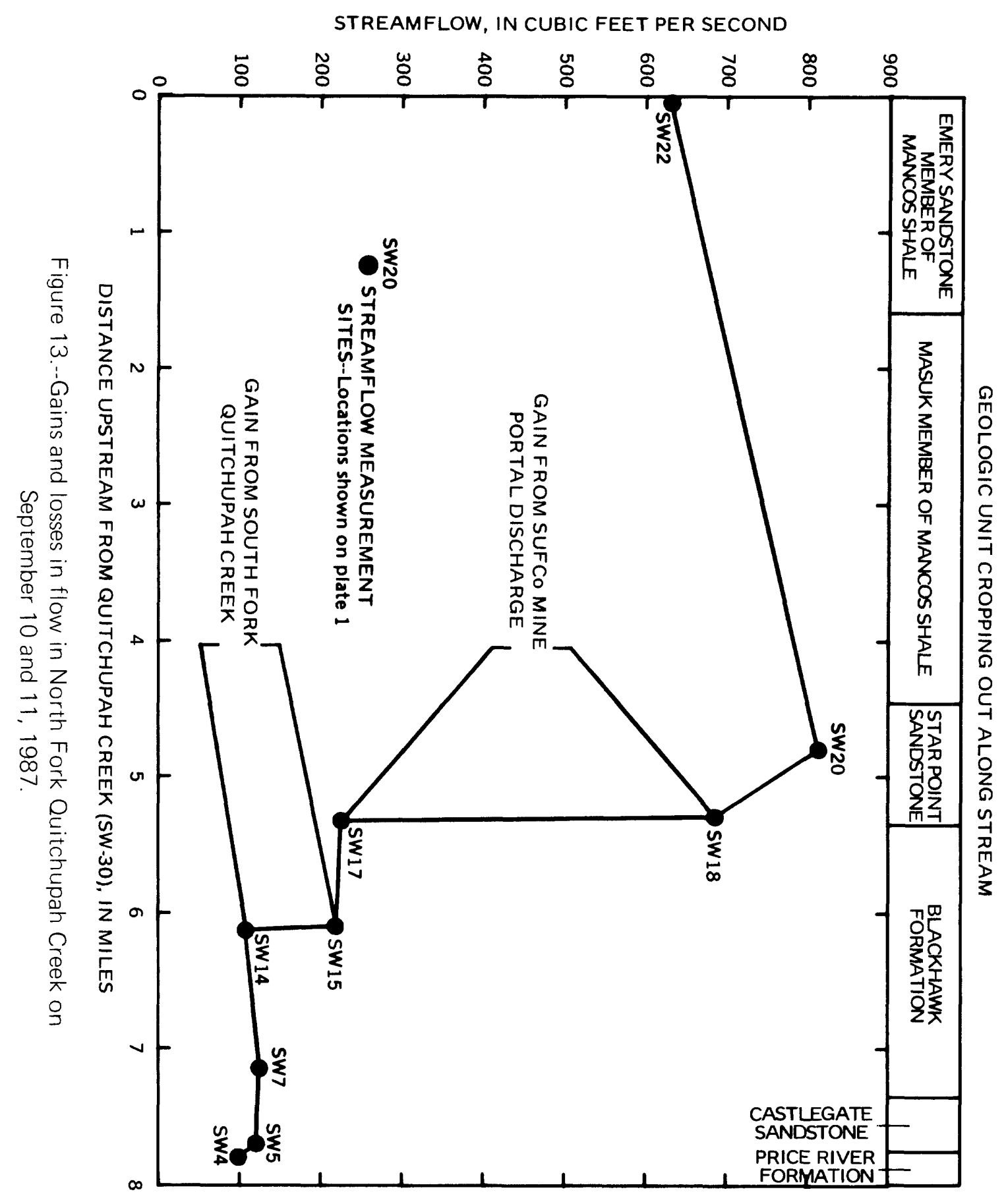




\section{Water Quality}

The chemical quality of ground water depends largely on the mineralogic character of the formation with which it has contact. The physical and chemical properties of ground water in the study area are summarized in table 6. Water in the upper part of the Castlegate Sandstone has the smallest concentration of dissolved solids, $61 \mathrm{mg} / \mathrm{L}$, while water in the lower part of the North Horn Formation has the largest concentration of dissolved solids, $1,080 \mathrm{mg} / \mathrm{L}$. Ground water from different parts of the Castlegate Sandstone contains about the same proportion of the dominant ions (fig. 14).

Solubility indices for calcite, dolomite, gypsum, anhydrite, and magnesite were computed for ground water from selected springs and mine inflows using the geochemical model PHREEQE (Parkhurst and others, 1980) (table 7). The solubility index for a particular mineral indicates the equilibrium state for that mineral based on milliequivalent concentrations of certain anions and cations, $\mathrm{pH}$, and temperature of the water. Water is supersaturated with respect to a specified mineral if the solubility index is greater than 0; saturated or at equilibrium with a specified mineral if the solubility index equals 0 ; and undersaturated with a specified mineral if the solubility index is less than 0 . The solubility indices indicate that water from most formations in the study area is undersaturated with respect to gypsum, anhydrite, and magnesite. The Castlegate Sandstone generally is undersaturated with respect to calcite and dolomite; whereas, most water samples from the Flagstaff Limestone, the North Horn Formation, and the Price River Formation are supersaturated with respect to calcite and dolamite.

\section{Flagstaff Limestone and the North Horn Formation}

Much recharge occurs on outcrops of the Flagstaff Limestone and North Horn Formation to the west of the study area in the upper reaches of the plateau. Downward percolation of this recharge into underlying strata is probably slow, impeded by less permeable shale layers within the North Horn Formation. Where faulting has broken the continuity of these shale layers, vertical movement of water may recharge the underlying formations. Aquifers in the Blackhawk Formation and Star Point Sandstone probably are recharged in this manner (Danielson and Sylla, 1983, p. 24).

The majority of springs and seeps in the Ferron Mountain-Flagstaff Peak area, about 4 miles north of the study area, were located in 1980 by Danielson and Sylla (1983). They found that 90 percent of the springs and seeps inventoried discharged from the North Horn Formation, yet their data were not sufficient to determine if the aquifer in the North Horn Formation is perched or part of a continuous saturated zone. A lack of data also prevents a definition of the ground-water system within the North Horn Formation in the Quitchupah and Pines study area. Monitoring wells installed by the SUFCo mine are the only measurable wells located in the study area. No water production wells are known to have been drilled in the study area.

Water flowing from a spring in the North Horn Formation at (D-21-5)8aaaSl had a dissolved solids concentration (residue at $180^{\circ} \mathrm{C}$ ) of $447 \mathrm{mg} / \mathrm{L}$. The main constituents were sodium, magnesium, and bicarbonate. While this was the only spring found in the study area that discharged directly from the North Horn Formation, some springs sampled by Danielson and Sylla (1983) in the 
Table 6.-Chemical analyses of wate

[ $\mu \mathrm{S} / \mathrm{cm}$, microsiemens per centimeter at 25 degrees Celsius; ${ }^{\circ} \mathrm{C}$, degrees Celsius; $\mathrm{mg} / \mathrm{L}$, milligrams Location: See page 5 for an explanation of the numbering system for ground-water sites. Mine sites are projected to land surface. Geologic unit: Formation from which spring or mine is discharging: Kbh, Blackhank formation; Kc, Castlegate Sandstone; Kpr, Price River Specific conductance: Measured in field except where noted $L$ (laboratory value).

\begin{tabular}{|c|c|c|c|c|c|c|c|c|c|c|c|c|c|c|c|c|}
\hline Location & $\begin{array}{c}\text { Site } \\
\text { number } \\
\text { (p1. 1) }\end{array}$ & Geologic & c Date & $\begin{array}{l}\text { Spe- } \\
\text { cifjc } \\
\text { conduct- } \\
\text { ance } \\
(\mu S / \mathrm{cm})\end{array}$ & $\begin{array}{l}\text { pH } \\
\text { (stand- } \\
\text { ard } \\
\text { units) }\end{array}$ & $\begin{array}{l}\text { Water } \\
\text { temper- } \\
\text { ature } \\
\left({ }^{\circ} \mathrm{C}\right)\end{array}$ & $\begin{array}{l}\text { Hard- } \\
\text { ness } \\
(\mathrm{mg} / \mathrm{L} \\
\text { as } \\
\left.\mathrm{CaCO}_{3}\right)\end{array}$ & $\begin{array}{l}\text { Akla- } \\
\text { linity } \\
\text { (mg/L } \\
\text { as } \\
\left.\mathrm{CaCO}_{3}\right)\end{array}$ & $\begin{array}{l}\text { Solids, } \\
\text { sum of } \\
\text { consti- } \\
\text { tuents, } \\
\text { dis- } \\
\text { solved } \\
(\mathrm{mg} / \mathrm{L})\end{array}$ & $\begin{array}{l}\text { Solids, } \\
\text { residue } \\
\text { - at } 180 \\
\text { oc, } \\
\text { dis- } \\
\text { solved } \\
\text { (mg/h) }\end{array}$ & $\begin{array}{l}\text { è } \\
\text { Calcium, } \\
\text { dis- } \\
\text { solved } \\
\text { (mg/h } \\
\text { as Ca) }\end{array}$ & $\begin{array}{l}\text { Magne- } \\
\text { sium, } \\
\text { dis- } \\
\text { solved } \\
\text { (mg/h } \\
\text { as } \mathrm{mg})\end{array}$ & $\begin{array}{l}\text { Sodium, } \\
\text { dis- } \\
\text { solved } \\
\text { (mg/L } \\
\text { as } \mathrm{Na} \text { ) }\end{array}$ & $\begin{array}{l}\text { Potas- } \\
\text { sium, } \\
\text { dis- } \\
\text { solved } \\
\text { (mg/h } \\
\text { as } \mathrm{k} \text { ) }\end{array}$ & $\begin{array}{l}\text { Sulfate, } \\
\text { dis- } \\
\text { solved } \\
(\mathrm{mg} / \mathrm{L} \\
\left.\text { as } \mathrm{SO}_{4}\right)\end{array}$ & $\begin{array}{r}\text { Ch } \\
\text { rid } \\
\text { di } \\
\text { sol } \\
\text { (m } \\
\text { ) as }\end{array}$ \\
\hline $\begin{array}{l}(D-2 a-5) 31 a b d-S 1 \\
(D-2 a-5) 32 b b c-S 1 \\
(D-2 a-5) 33 c c c-S 1 \\
(D-21-4) 22 b d b-S 1\end{array}$ & $\begin{array}{l}\text { GN-1 } \\
\text { GN-2 } \\
\text { GN-3 } \\
\text { GN-4 }\end{array}$ & $\begin{array}{l}\text { Kpr } \\
\mathrm{Kpr} \\
\mathrm{Kpr} \\
\mathrm{Kpr}\end{array}$ & $\begin{array}{l}08-09-79 \\
07-15-86 \\
09-25-76 \\
08-20-86 \\
09-17-76\end{array}$ & $\begin{array}{c}750 \mathrm{~L} \\
700 \\
800 \\
1,130 \\
1,200\end{array}$ & $\begin{array}{l}7.0 \\
7.5 \\
7.3 \\
7.2 \\
8.6\end{array}$ & $\begin{array}{r}12.0 \\
6.5 \\
13.0 \\
9.5 \\
8.0\end{array}$ & $\begin{array}{l}320 \\
320 \\
320 \\
400 \\
300\end{array}$ & $\begin{array}{l}350 \\
250 \\
367 \\
344 \\
551\end{array}$ & $\begin{array}{r}<440 \\
340 \\
450 \\
620 \\
790\end{array}$ & $\begin{array}{r}\overline{-} \\
\overline{720} \\
\overline{--}\end{array}$ & $\begin{array}{l}72 \\
73 \\
74 \\
77 \\
42\end{array}$ & $\begin{array}{l}35 \\
34 \\
33 \\
51 \\
46\end{array}$ & $\begin{array}{r}39 \\
27 \\
54 \\
80 \\
200\end{array}$ & $\begin{array}{l}1.8 \\
1.4 \\
2.1 \\
2.6 \\
7.2\end{array}$ & $\begin{array}{r}26 \\
18 \\
24 \\
100 \\
110\end{array}$ & $\begin{array}{l}46 \\
25 \\
32 \\
85 \\
39\end{array}$ \\
\hline$\left(\begin{array}{l}(D-21-4 \\
(D-21-4\end{array}\right)^{26 b d a-S 1} 34 \mathrm{cod}-\mathrm{S1}$ & $\begin{array}{l}G W-6 \\
\text { GW-8 }\end{array}$ & $\begin{array}{l}\text { TKrh } \\
\text { Kpr }\end{array}$ & $\begin{array}{l}08-05-86 \\
08-19-86 \\
09-16-76 \\
07-01-79 \\
09-27-79\end{array}$ & $\begin{array}{l}640 \\
1,890 \\
1,210 \\
1,100 \\
1,220 \mathrm{~L}\end{array}$ & $\begin{array}{l}7.5 \\
7.3 \\
7.7 \\
7.5 \\
7.7\end{array}$ & $\begin{array}{r}6.0 \\
10.5 \\
10.0 \\
7.0 \\
10.0\end{array}$ & $\begin{array}{l}340 \\
280 \\
320 \\
320 \\
350\end{array}$ & $\begin{array}{l}330 \\
380 \\
424 \\
260 \\
400\end{array}$ & $\begin{array}{r}370 \\
1,000 \\
790 \\
650 \\
770\end{array}$ & $\begin{array}{r}295 \\
1,080 \\
-- \\
-- \\
--\end{array}$ & $\begin{array}{l}78 \\
84 \\
76 \\
79 \\
84\end{array}$ & $\begin{array}{l}36 \\
18 \\
32 \\
29 \\
33\end{array}$ & $\begin{array}{r}19 \\
320 \\
160 \\
110 \\
160\end{array}$ & $\begin{array}{l}1.2 \\
2.0 \\
3.9 \\
3.3 \\
4.2\end{array}$ & $\begin{array}{l}22 \\
120 \\
190 \\
190 \\
180\end{array}$ & $\begin{array}{r}2 \\
230 \\
54 \\
71 \\
52\end{array}$ \\
\hline 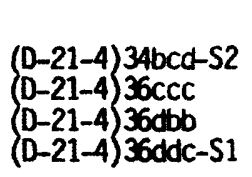 & $\begin{array}{l}\text { GW-9 } \\
\text { GW-10 } \\
\text { GW-11 } \\
\text { GW-12 }\end{array}$ & $\begin{array}{l}\mathrm{Kpr} \\
\mathrm{Kbh} \\
\mathrm{Kbh} \\
\mathrm{Kc}\end{array}$ & $\begin{array}{l}09-17-86 \\
08-05-86 \\
07-23-80 \\
07-23-80 \\
08-22-86\end{array}$ & $\begin{array}{r}1,340 \\
1,170 \\
680 \\
540 \\
470\end{array}$ & $\begin{array}{l}7.4 \\
7.7 \\
7.8 \\
7.6 \\
6.9\end{array}$ & $\begin{array}{r}7.0 \\
7.5 \\
10.0 \\
9.0 \\
6.5\end{array}$ & $\begin{array}{l}410 \\
390 \\
340 \\
270 \\
220\end{array}$ & $\begin{array}{l}329 \\
306 \\
310 \\
240 \\
189\end{array}$ & $\begin{array}{l}800 \\
670 \\
360 \\
290 \\
260\end{array}$ & $\begin{array}{r}820 \\
689 \\
-- \\
\overline{296}\end{array}$ & $\begin{array}{r}100 \\
98 \\
74 \\
64 \\
56\end{array}$ & $\begin{array}{l}40 \\
35 \\
37 \\
27 \\
20\end{array}$ & $\begin{array}{l}140 \\
110 \\
8.7 \\
7.7 \\
12\end{array}$ & $\begin{array}{l}3.4 \\
3.6 \\
1.8 \\
1.9 \\
1.4\end{array}$ & $\begin{array}{r}230 \\
170 \\
29 \\
23 \\
20\end{array}$ & $\begin{array}{l}76 \\
61 \\
11 \\
11 \\
22\end{array}$ \\
\hline $\begin{array}{l}(D-21-5) \text { 8aaa-S1 } \\
(D-21-5 \\
(D-21-5 \\
(D-21-5) \\
(0 b a b-S 1 \\
11 b b b-S 1\end{array}$ & $\begin{array}{l}\text { GW-13 } \\
\text { GW-14 } \\
\text { GN-15 } \\
\text { GW-16 }\end{array}$ & $\begin{array}{l}\text { TKmh } \\
\mathrm{Kbh} \\
\mathrm{KC} \\
\mathrm{KC}\end{array}$ & $\begin{array}{l}10-10-86 \\
09-18-86 \\
09-16-86 \\
09-16-86 \\
09-19-86\end{array}$ & $\begin{array}{l}450 \\
800 \\
310 \\
215 \\
320\end{array}$ & $\begin{array}{l}7.4 \\
7.6 \\
7.5 \\
6.9 \\
8.2\end{array}$ & $\begin{array}{l}7.0 \\
7.0 \\
7.5 \\
6.5 \\
4.0\end{array}$ & $\begin{array}{r}220 \\
280 \\
140 \\
85 \\
170\end{array}$ & $\begin{array}{r}193 \\
341 \\
123 \\
69 \\
159\end{array}$ & $\begin{array}{l}260 \\
460 \\
170 \\
120 \\
200\end{array}$ & $\begin{array}{l}260 \\
447 \\
200 \\
160 \\
232\end{array}$ & $\begin{array}{l}55 \\
47 \\
36 \\
23 \\
43\end{array}$ & $\begin{array}{l}20 \\
39 \\
12 \\
6.8 \\
15\end{array}$ & $\begin{array}{l}12 \\
72 \\
8.2 \\
8.9 \\
7.9\end{array}$ & $\begin{array}{l}1.4 \\
2.3 \\
1.2 \\
1.2 \\
1.3\end{array}$ & $\begin{array}{l}22 \\
28 \\
23 \\
22 \\
18\end{array}$ & $\begin{array}{l}21 \\
55\end{array}$ \\
\hline 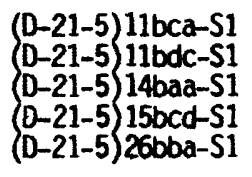 & $\begin{array}{l}\text { GN-17 } \\
\text { GN-18 } \\
\text { GN-19 } \\
\text { GN-20 } \\
\text { GW-21 }\end{array}$ & $\begin{array}{l}\mathrm{Kc} \\
\mathrm{Kc} \\
\mathrm{Kc} \\
\mathrm{Kc} \\
\mathrm{Kc}\end{array}$ & $\begin{array}{l}09-19-86 \\
09-19-86 \\
08-19-86 \\
09-16-86 \\
08-11-79\end{array}$ & $\begin{array}{l}290 \\
345 \\
105 \\
215 \\
310\end{array}$ & $\begin{array}{l}7.1 \\
8.0 \\
5.9 \\
6.8 \\
7.5\end{array}$ & $\begin{array}{r}7.0 \\
5.5 \\
9.0 \\
7.0 \\
20.5\end{array}$ & $\begin{array}{r}120 \\
160 \\
35 \\
79 \\
120\end{array}$ & $\begin{array}{r}124 \\
148 \\
31 \\
75 \\
96\end{array}$ & $\begin{array}{l}160 \\
200 \\
55 \\
120 \\
160\end{array}$ & $\begin{array}{r}188 \\
236 \\
83 \\
142 \\
--\end{array}$ & $\begin{array}{l}33 \\
42 \\
10 \\
22 \\
35\end{array}$ & $\begin{array}{l}10 \\
13 \\
2.4 \\
5.8 \\
8.5\end{array}$ & $\begin{array}{r}8.6 \\
9.3 \\
3.5 \\
9.4 \\
12\end{array}$ & $\begin{array}{l}1.1 \\
1.4 \\
1.1 \\
1.7 \\
1.3\end{array}$ & $\begin{array}{l}12 \\
22 \\
9.7 \\
20 \\
20\end{array}$ & 11 \\
\hline $\left.\begin{array}{l}(D-21-5) \\
(D-21-5 \\
(D-21-5 \\
(D-21-5\end{array}\right) 31 d \mathrm{cdb}$ & $\begin{array}{l}G W-22 \\
G W-24 \\
\text { GW-25 } \\
\text { GN-26 }\end{array}$ & $\begin{array}{l}\mathrm{Kbh} \\
\mathrm{Kbh} \\
\mathrm{Kbh} \\
\mathrm{Kbh}\end{array}$ & $\begin{array}{l}07-15-86 \\
07-15-86 \\
10-10-86 \\
10-10-86 \\
07-23-80\end{array}$ & $\begin{array}{l}300 \\
800 \\
860 \\
600 \\
530\end{array}$ & $\begin{array}{l}7.5 \\
7.5 \\
7.3 \\
7.6 \\
7.3\end{array}$ & $\begin{array}{r}6.5 \\
14.5 \\
12.0 \\
10.5 \\
11.0\end{array}$ & $\begin{array}{l}120 \\
340 \\
410 \\
340 \\
250\end{array}$ & $\begin{array}{l}108 \\
334 \\
251 \\
266 \\
220\end{array}$ & $\begin{array}{l}170 \\
490 \\
590 \\
380 \\
270\end{array}$ & $\begin{array}{l}162 \\
488 \\
613 \\
314\end{array}$ & $\begin{array}{l}33 \\
72 \\
93 \\
84 \\
60\end{array}$ & $\begin{array}{l}8.3 \\
40 \\
42 \\
31 \\
25\end{array}$ & $\begin{array}{c}14 \\
45 \\
42 \\
7.2 \\
6.9\end{array}$ & $\begin{array}{l}1.4 \\
2.8 \\
3.1 \\
1.5 \\
1.5\end{array}$ & $\begin{array}{r}19 \\
110 \\
240 \\
77 \\
27\end{array}$ & $\begin{array}{r}10 \\
9 \\
11\end{array}$ \\
\hline $\begin{array}{l}(D-22-4) 1 b c b \\
(D-22-4) 12 b d b\end{array}$ & $\begin{array}{l}\text { GW-27 } \\
\text { GW-28 }\end{array}$ & $\begin{array}{l}\mathrm{Kbh} \\
\mathrm{Kbh}\end{array}$ & $\begin{array}{l}05-02-79 \\
09-27-76 \\
09-01-78\end{array}$ & $\begin{array}{l}680 \\
475 \\
640\end{array}$ & $\begin{array}{l}7.1 \\
8.3 \\
7.1\end{array}$ & $\begin{array}{l}11.0 \\
10.0 \\
11.0\end{array}$ & $\begin{array}{l}340 \\
240 \\
310\end{array}$ & $\begin{array}{l}300 \\
189 \\
200\end{array}$ & $\begin{array}{l}360 \\
270 \\
370\end{array}$ & $\begin{array}{l}-- \\
--\end{array}$ & $\begin{array}{l}76 \\
47 \\
65\end{array}$ & $\begin{array}{l}36 \\
29 \\
37\end{array}$ & $\begin{array}{l}8.3 \\
11 \\
14\end{array}$ & $\begin{array}{l}2.3 \\
1.6 \\
2.0\end{array}$ & $\begin{array}{r}32 \\
53 \\
110\end{array}$ & $\begin{array}{l}4 \\
0\end{array}$ \\
\hline $\begin{array}{ll}(D-22-5) & 6 d b c \\
(D-22-5 & 7 a c a-S 1\end{array}$ & $\begin{array}{l}G W-29 \\
\text { GW-30 }\end{array}$ & $\begin{array}{l}\text { Kbh } \\
\text { Kc }\end{array}$ & $\begin{array}{l}05-02-79 \\
08-06-86\end{array}$ & $\begin{array}{r}590 \\
96\end{array}$ & $\begin{array}{l}7.0 \\
6.2\end{array}$ & $\begin{array}{r}12.0 \\
7.5\end{array}$ & $\begin{array}{r}310 \\
35\end{array}$ & $\begin{array}{r}190 \\
33\end{array}$ & 390 & $\overline{61}$ & $\begin{array}{l}58 \\
10\end{array}$ & $\stackrel{39}{2.5}$ & $\stackrel{28}{4.1}$ & $\begin{array}{l}2.8 \\
0.60\end{array}$ & $\begin{array}{l}130 \\
8.2\end{array}$ & \\
\hline
\end{tabular}




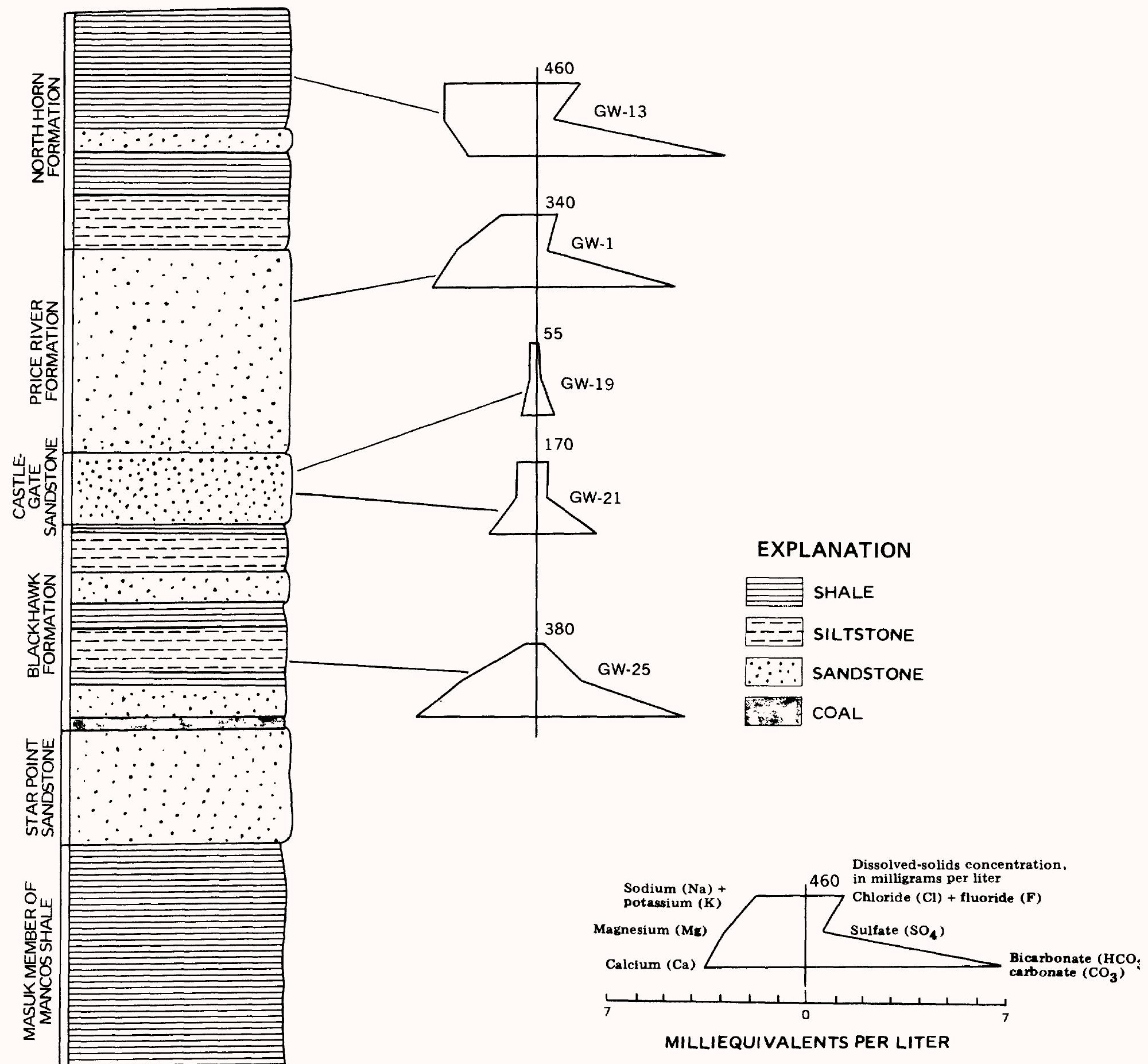

(Modified from Stiff, 1951)

Figure 14.--Generalized stratigraphic column for the study area and representative water-quality diagrams for selected units. 
Table 7.--Sumary of solubility indices for ground water

from selected springs and mine inflow sites

Location: See page 5 for an explanation of the numbering system for ground-water sites.

Solubility index: Log (activity product/solubility constant).

Geologic unit: Tf, Flagstaff Limestone; TKnh, North Horn Formation; Kpr. Price River Formation; KC, Castlegate Sandstone; Kbh, Blackhawk Formation.

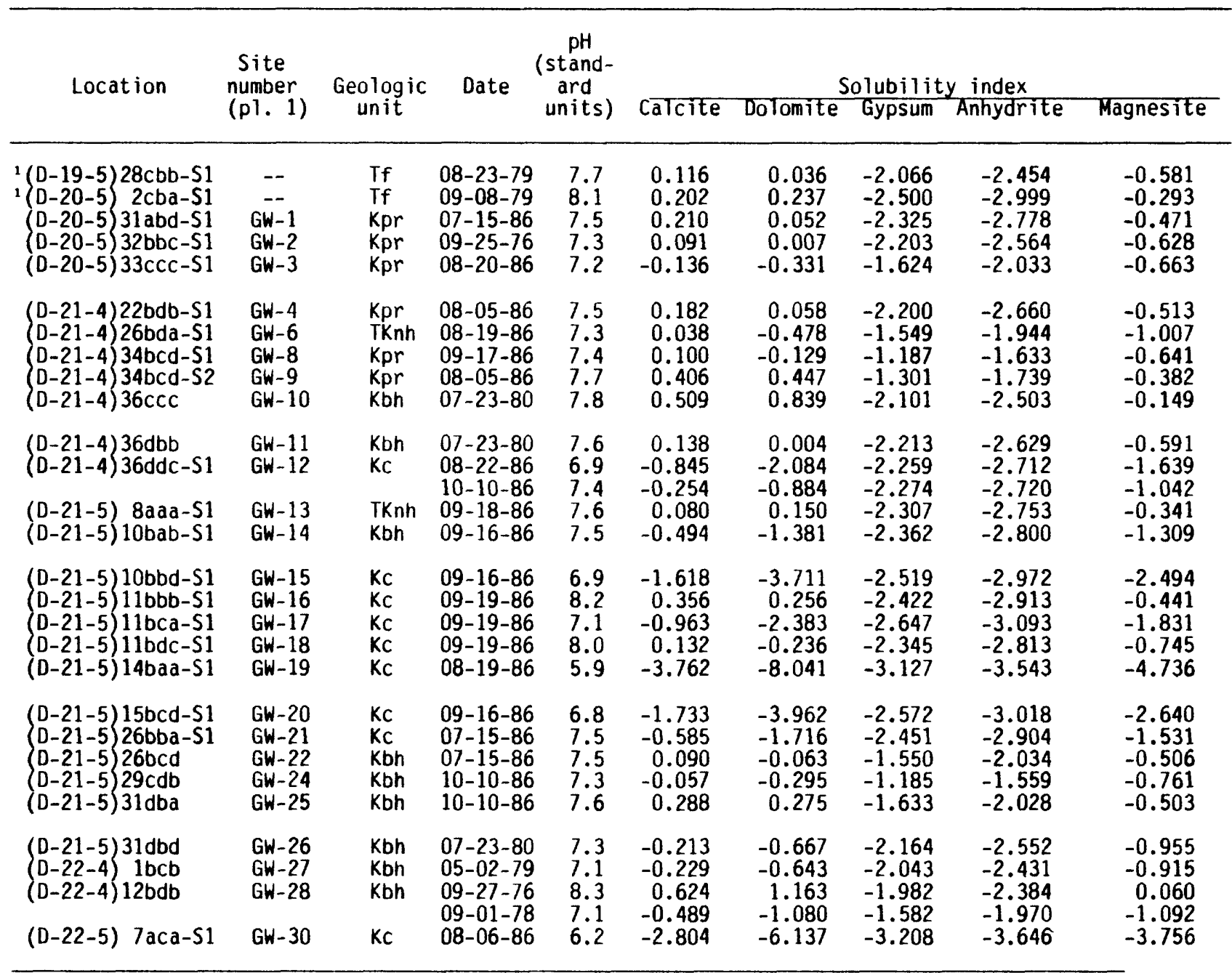

1 Spring is out of the study area.

Flagstaff Peak area to the north have similar chemical compositions. The springs and seeps near the top of Duncan Draw occur in alluvium near the Price River-North Horn Formation contact. Dominant ions in water discharging in this area are sodium and chloride, probably because of contact with evaporite layers within the North Horn Formation.

Analyses from two springs in the Flagstaff Peak area that originate from the Flagstaff Limestone (Danielson and Sylla, 1983) were used in table 7 for the comparison of different ground waters. 


\section{Price River Formation and the Castlegate Sandstone}

Recharge to the Price River Formation and the Castlegate Sandstone is primarily from the infiltration of precipitation. In the Trail Mountain area of the Wasatch Plateau, about 21 miles north of the study area, Lines (1985, p. 19) estimated that recharge to the Castlegate Sandstone is about 3.5 percent, and recharge to the Price River Formation is about 2.6 percent of the annual normal precipitation on the outcrop area. Outcrop areas for the Castlegate Sandstone and the Price River Formation in the coal-lease tracts are 5,250 and 7,040 acres, respectively. Using the rates for the Trail Mountain area, annual recharge to the Castlegate Sandstone and the Price River Formation in the Quitchupah and Pines coal-lease tracts would be about 336 acre-ft. However, the total spring discharge from the outcrop areas was estimated to be about $225 \mathrm{acre}-\mathrm{ft} / \mathrm{yr}$. Assuming that recharge to the strata is equal to the discharge from springs, $225 \mathrm{acre}-\mathrm{ft} / \mathrm{yr}$, and that the outcrops receive an average annual precipitation of 16 to $20 \mathrm{in.,}$ the annual recharge would be about 1.2 percent of the annual normal precipitation.

Discharge from the Castlegate Sandstone in June at East Spring correlates well with the cumulative departure of the annual peak water content measured at the Blacks Fork snow course for the same year (fig. 15). These data support the hypothesis that most recharge near East Spring is from snowpack and not from rainfall.

Ground water discharged from East Spring was analysed for tritium to determine the relative age of water recharging the Castlegate Sandstone. Tritium, a naturally occurring radioactive isotope of hydrogen, has a halflife of 12.26 years. Prior to the advent of above-ground nuclear testing in 1953, the tritium concentration in precipitation was about $26 \mathrm{pCi} / \mathrm{L}$. By 1963, concentrations had $r$ isen three orders of magnitude over natural levels (Thatcher and others, 1977, p. 8). The ground water discharged at East Spring contained $91.2 \mathrm{pCi} / \mathrm{L}$ of tritium. Because of the variability in the quantity of tritium added to the atmosphere since 1953, precise dating of this water is not possible, but some of the sampled water must have been recharged to the aquifer sometime after 1952 .

Fracturing and jointing of the rocks, particularly the Castlegate Sandstone, may provide conduits for rapid ground-water movement. The Castlegate Sandstone contains minor amounts of siltstone and shale locally, some of which may have the ability to expand and seal fractures. However, the Castlegate Sandstone is predominantly a friable, coarse-grained sandstone capable of transmitting water. Most of the perched ground water in the Castlegate Sandstone moves along bedding planes in the direction of dip. All of the springs found discharging from the Castlegate Sandstone are located on the east side of canyons, which is always downdip from recharge areas.

Transmissivity values for the Castlegate Sandstone in the Soldier Creek area of the Book Cliffs, about 60 miles northeast of the study area, were estimated by Waddell and others (1986) by a method similar to a slug test. A value of $0.02 \mathrm{ft}^{2} /$ day was computed for the upper part and $0.003 \mathrm{ft}^{2} /$ day for the lower part of the formation. These values probably represent a lower limit because the perforated zones in the test wells only partly penetrated the formations being tested. 


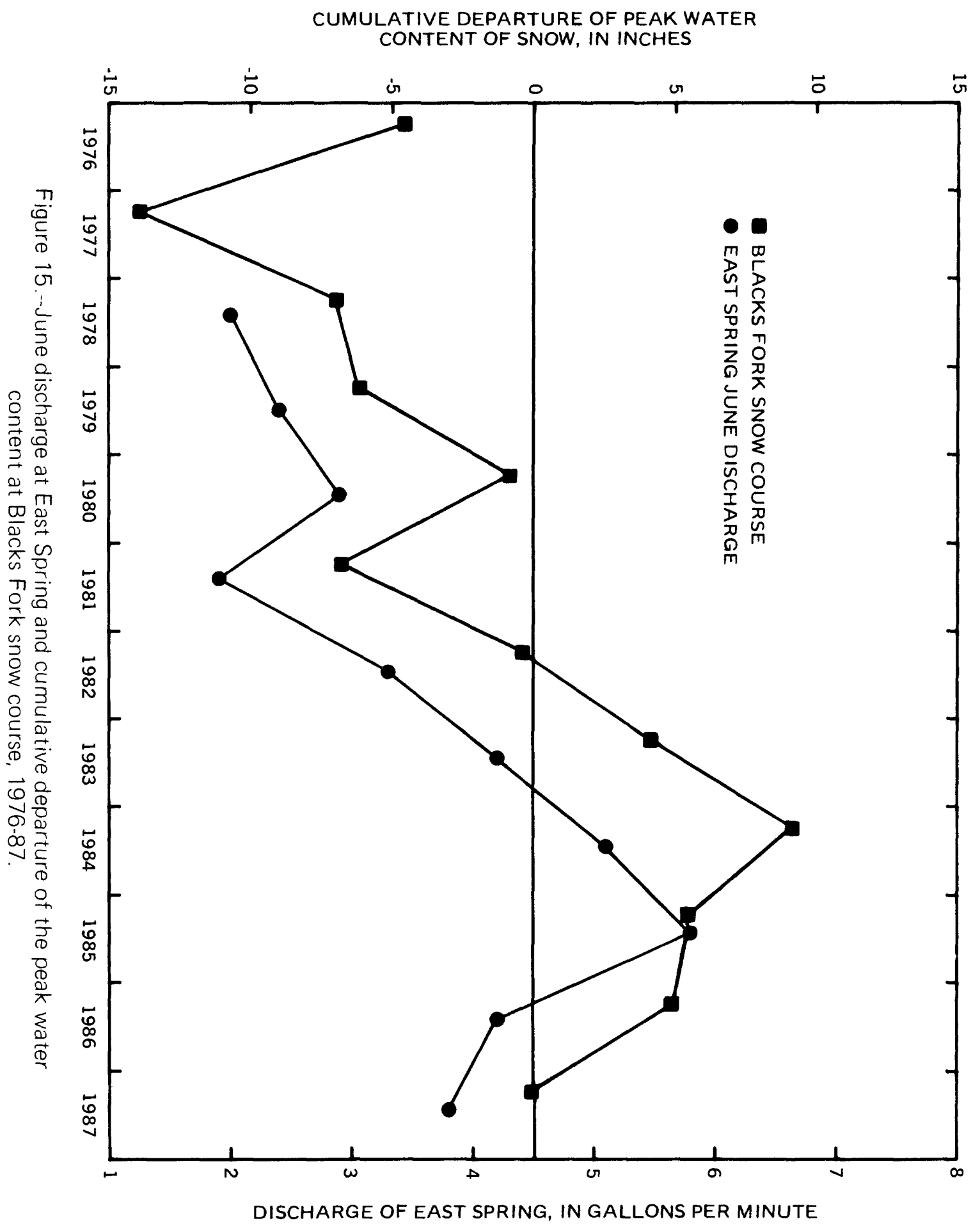


Springs discharging from the perched ground water in the Castlegate Sandstone respond quickly to changes in the rate of recharge. The largest discharge reported at East Spring, (D-21-4)36ddc-Sl, was $7.3 \mathrm{gal} / \mathrm{min}$ on October 11, 1984, as compared to $5.1 \mathrm{gal} / \mathrm{min}$ on June 21, 1984. Part of the increase in flow was in response to a storm on October 2 and 3,1984 ; total precipitation for this storm was 2.3 inches at the Emery 15 SW weather station. These data suggest the time of travel through the Castlegate Sandstone is very short.

The majority of the springs found in the area issue from the base of Castlegate Sandstone. Springs located in the Price River Formation include $(D-20-5) 33 c c c-S 1$, at the base, (D-20-5) 31 abd-Sl, (D-20-5) 32bbc-Sl, and (D-21-4) 22bdb-S1, within the formation, and (D-21-4) 34bcd-S1 and S2, controlled by a fault.

Many springs and seeps discharge from the base of the Castlegate Sandstone on the east side of Box Canyon and East Fork Box Canyon. One spring, (D-21-5)10bab-Sl, discharging from the top of the Blackhawk Formation, is similar in chemical composition to water from the Castlegate Sandstone, and indicates recharge to the Blackhawk Formation is most likely from the Castlegate Sandstone. Seeps were noted along same bedding planes near the base of the Castlegate Sandstone. The seepage seems to be most common where the sandstone is thinly bedded or irregular.

The flow from two springs discharging at the base of the Castlegate Sandstone was measured periodically during 1986 and 1987. Discharge hydrographs for East Spring and (D-21-5)26bba-Sl, at the top of Link Canyon, both showed similar periods of increasing and declining flow (fig. 16). East Spring, monitored by SUFCo since 1977, is the only spring in the area with long-term reoord (fig. 17).

Constituents in water from springs discharging from the Price River Formation vary because of structural controls. Lizonbee Springs discharge along a fault which extends 2.5 miles north from Acord Lakes. The dominant ions in the water are sodium, bicarbonate, and sulfate. Other springs flowing from the Price River Formation in the Greens Hollow area to the south discharge water containing calcium, magnesium, and bicarbonate as the main constituents.

Lizonbee Springs discharge water from the Price River Formation that is saturated with respect to calcite, yet sodium is the dominant cation. This can be caused by sulfate reduction or cation exchange, but the latter is the most likely process occurring here. Saturated material such as the Price River Formation, which contains calcite and clay minerals with exchangeable sodium ions, can produce, through cation exchange, sodium bicarbonate waters. In the cation exchange process, dissolved calcium in the ground water is exchanged for sodium from the minerals (Waddell and others, 1986, p. 33).

The Castlegate Sandstone discharges calcium bicarbonate water throughout the study area. Dissolved solids range from $61 \mathrm{mg} / \mathrm{L}$ for water discharging near the top of the sandstone to $296 \mathrm{mg} / \mathrm{L}$ for water at the base. Water discharging from springs near the top of the Cast legate Sandstone is probably only recently recharged and has not had sufficient contact with the formation to acquire a concentration of dissolved constituents similar to that of water discharging near the base of the formation. 


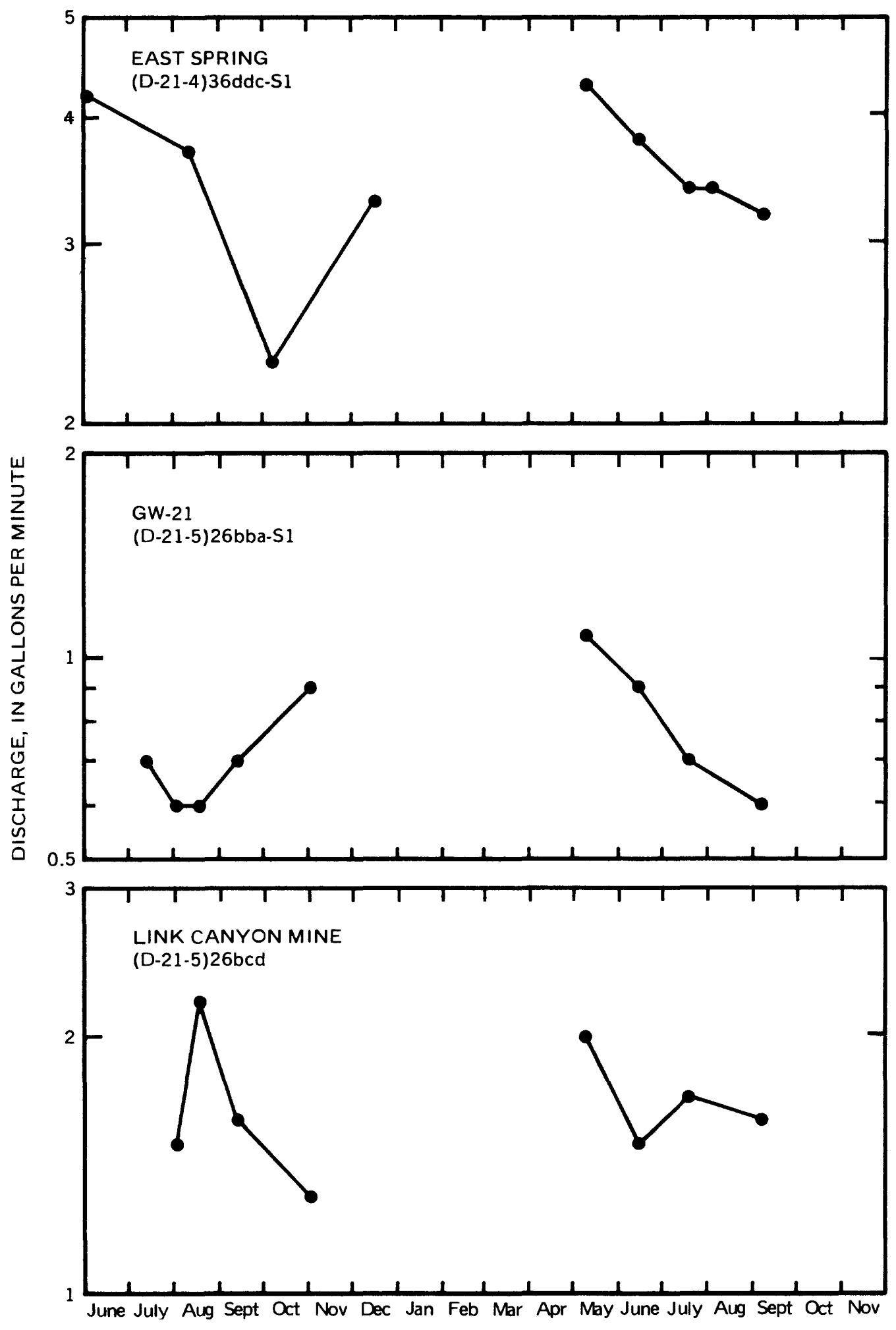

Figure 16.--Discharge of springs (D-21-4)36ddc-S1 and (D-21-5) 26bba-S1, and mine outflow (D-21-5)26bcd, 1986-87. 


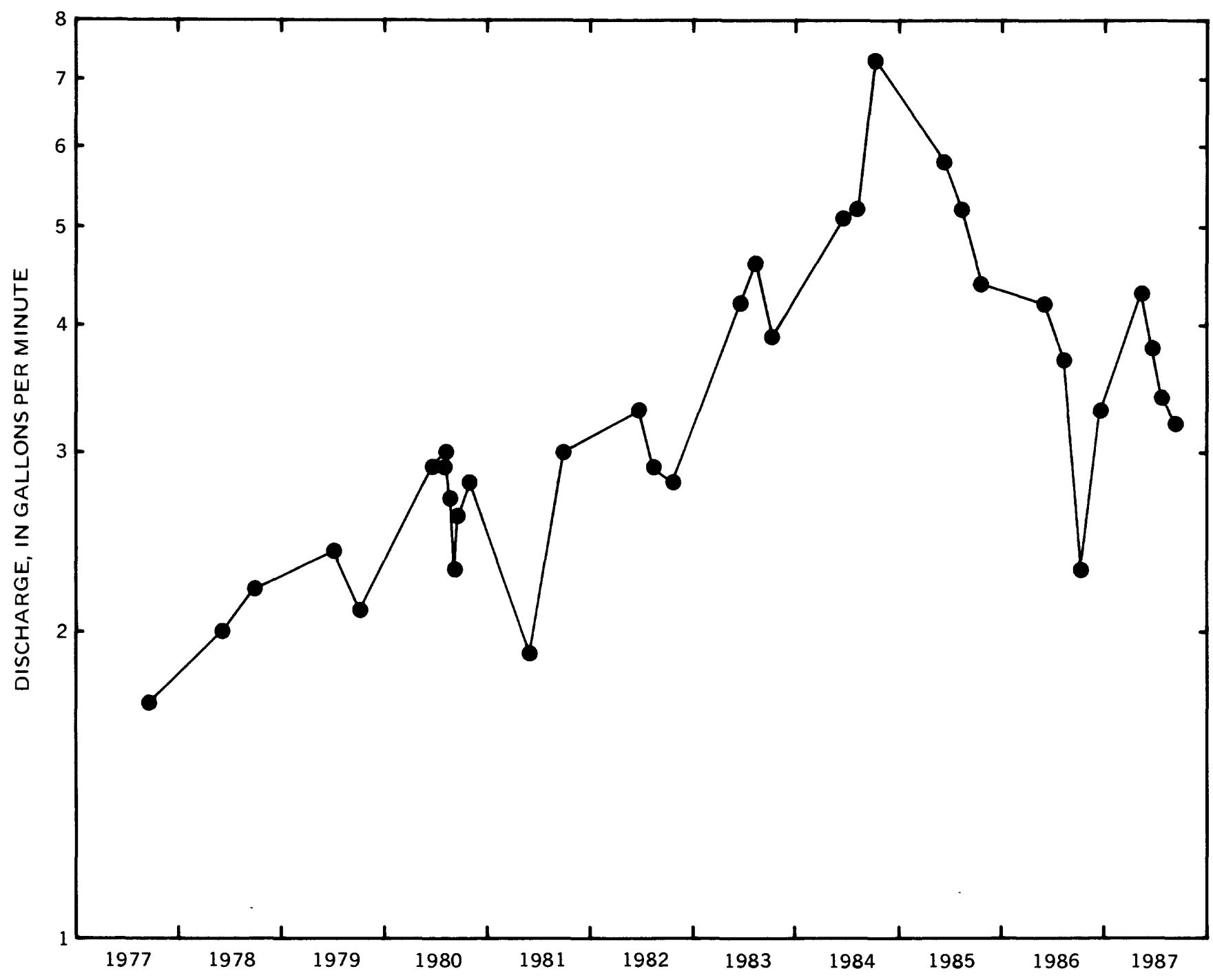

Figure 17.--Discharge measured at East Spring, (D-21-4)36ddc-S1, 1977-87.

Water discharged by the Castlegate Sandstone is undersaturated with respect to calcite and dolomite in most of the springs sampled. The data from table 7 indicate that most of the ground-water discharging from other strata in the study area is saturated or supersaturated with respect to calcite and dolomite regardless of the water's chemical composition.

\section{Blackhawk Formation and the Star Point Sandstone}

The Blackhawk Formation and the Star Point Sandstone are usually saturated everywhere within the study area except at outcrops at the edge of the plateau, in canyons incised into the plateau, and near the SUFCo mine where dewatering is occurring. Impermeable layers within the Blackhawk Formation may create localized perched zones above the saturated zone. The Blackhawk Formation and Star Point Sandstone are the principal sources of water entering underground mines in the Wasatch Plateau coal field (Lines, 1985 , p. 7). 


\section{Aquifer Properties}

Aquifer tests using pumped wells penetrating the Blackhawk Formation and Star Point Sandstone were conducted by Lines (1985) in the Trail Mountain area. Computed transmissivity values ranged from 2 to $100 \mathrm{ft}^{2} / \mathrm{day}$. A transmissivity value of $100 \mathrm{ft}^{2} /$ day is greater than would be expected based on porosity and hydraulic conductivity values determined from a sample of the aquifer material. The large transmissivity value is attributed to secondary permeability from fractures.

Hydrometrics (1983) calculated a transmissivity value of $60 \mathrm{ft}^{2} /$ day using the slug test method at a well penetrating the upper Hiawatha coal seam. The accuracy of this value is unknown because the well had not been developed and the casing extended $80 \mathrm{ft}$ beyond the bottom of the coal seam with an open or partially filled annular space. However, the value is within the range computed from previous aquifer tests in the Blackhawk Formation.

\section{Recharge}

Recharge to the Blackhawk Formation and Star Point Sandstone from direct infiltration of precipitation at the outcrop is probably small because of the limited exposures resulting from variable surface relief. Most recharge to the Blackhawk Formation and Star Point Sandstone is probably from vertical leakage of water through fractures in overlying formations.

A water sample collected from a fault in the Blackhawk Formation in the SUFCo mine was tested for tritium concentration to determine the approximate age of recharge. The sample from the Blackhawk Formation contained less than $0.5 \mathrm{pCi} / \mathrm{L}$ of tritium. According to Tyler B. Coplen (U.S. Geological Survey, written commun., 1987), water with a tritium content less than $3.2 \mathrm{pCi} / \mathrm{L}$ was recharged to an aquifer prior to 1953; when above-ground nuclear testing began. Assuming a natural tritium concentration of $26 \mathrm{pCi} / \mathrm{L}$ before that date and no mixing with other ground water, the mine inflow must have entered the ground-water system at least 70 years ago.

\section{Movement}

Direction and rate of ground-water movement in the study area could not be determined because of the sparsity of water-level data. Ground-water flow is controlled mainly by orientation of fractures, the dip direction of strata, and the hydraulic conductivity of the rocks.

Artesian pressure exists at some locations within the study area. Four observation wells in the vicinity of Duncan Mountain were completed by SUFCo to monitor water levels in the upper Hiawatha coal seam (fig. 18). Water levels for wells (D-2l-4)25bbb-1, (D-2l-4) 25ccc-1, (D-2l-4) 25dcd-1, and $(\mathrm{D}-21-5) 30 \mathrm{cbc}-1$ are 129 to $315 \mathrm{ft}$ above the top of the upper Hiawatha coal seam (table 8 ).

Three other monitoring wells located near the edge of the Wasatch Plateau, (D-22-5)8bbc-1, (D-22-5)8ac, and (D-22-5) 5cad-1, are dry. They also are perforated at the upper Hiawatha coal seam but are located between the eastern edge of the Wasatch Plateau and the SUFCo mine. The Blackhawk Formation and Star Point Sandstone have been dewatered in this area. Lines 
(1985, p. 15) determined that the potentiometric surface in the Blackhawk Formation and the Star Point Sandstone in the Trail Mountain area decreased in altitude with increased depth. This indicates that the potential exists for water to move downward from the Hiawatha coal seam.

\section{Discharge}

No springs discharging from the Blackhawk Formation were found in the study area, but two mines penetrate the base of the formation. The SUFCo mine intercepts ground water in the upper Hiawatha coal seam of the Blackhawk Formation. The longwall mining method, where all of the coal in an area is extracted leaving the roof unsupported, has been practiced at the SUFCo mine since the early $1980^{\prime} \mathrm{s}$. Water is usually produced at the new faces of the longwall panels for a short time. Mined faces in the older southern part of the mine, where the room and pillar method of mining was used, are generally dry now. Water also seeps into the SUFCo mine from paleochannel sandstones exposed in the mine above the coal bed. Discharge measurements for (D-21-5) 26bcd, issuing from a collapsed portal at the abandoned Link Canyon Mine, indicate some seasonal variation in flow (fig. 16).

\section{Water Quality}

The predominant ions in water samples collected at bolt holes and fractures in the roof of the SUFCo mine were calcium, magnesium, and bicarbonate. Water discharged from the mine after flowing through a sump system showed a substantial increase in sulfate, most likely because of the axidation of sulfide minerals in the coal seam. Also, same of the increase in sulfate concentrations may be attributed to the dissolution of gypsum that is used in the mine for dust control. Ground water discharging from an abandoned portal of the Link Canyon Mine, which also intersects the lower part of the Blackhawk Formation, had a composition similar to that of water found in the SUFCo mine. Dissolved-solids concentrations (sum of constituents) in samples collected fram the Link Canyon and SUFCo mines range from 270 to $590 \mathrm{mg} / \mathrm{L}$.

The large concentrations of magnesium present in ground water collected from the Blackhawk Formation $(25-40 \mathrm{mg} / \mathrm{L}$ ) are unusual because no substantial source for the ion exists in the formation. Calcareous shales (Smith, 1981) in the Blackhawk Formation may account for some of the magnesium. 

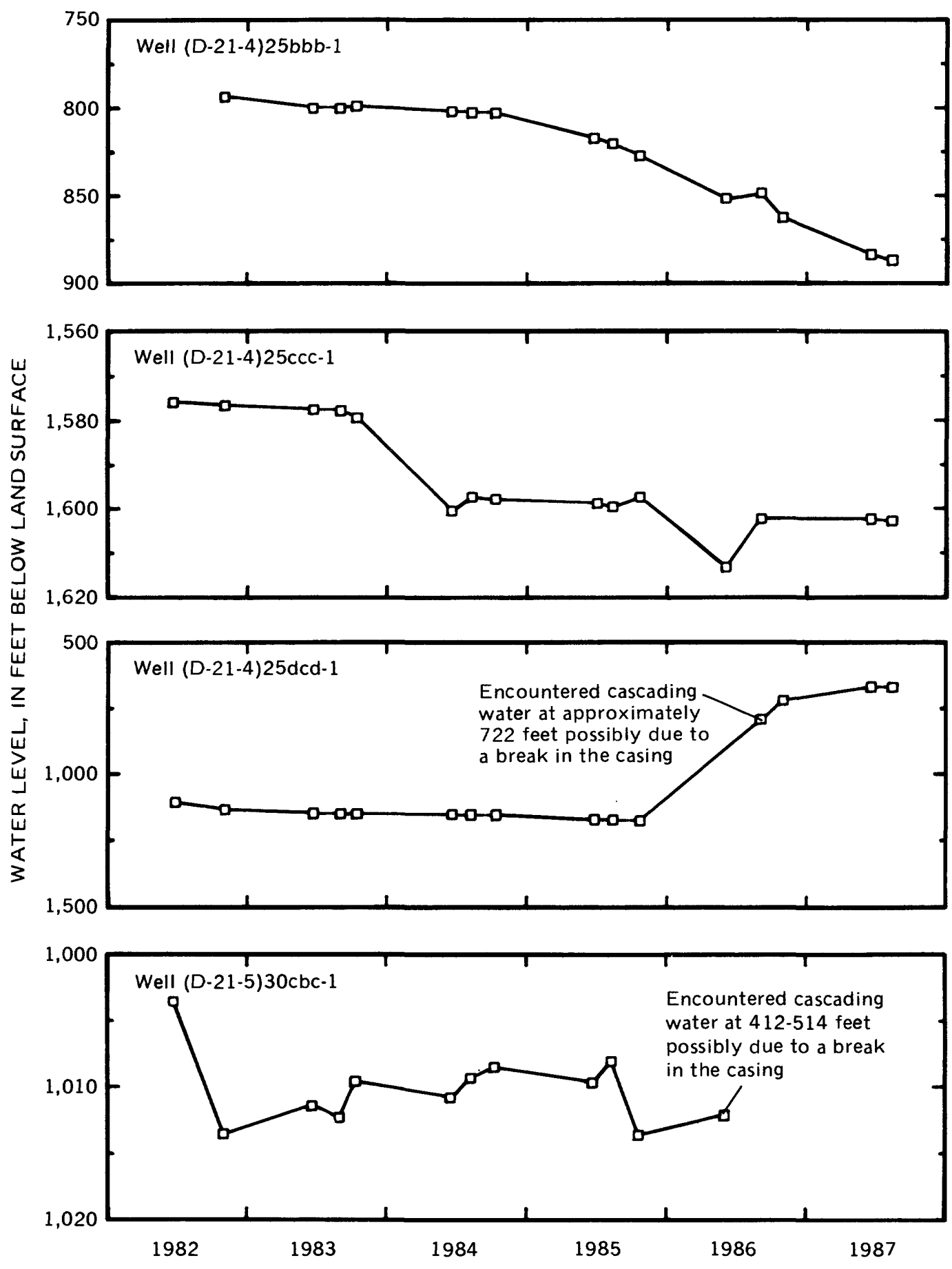

Figure 18.--Water-level changes in selected SUFCo monitoring wells completed in the upper Hiawatha coal seam of the Blackhawk Formation. 
Table 8.--Geologic and hydrologic data from

Location: See page 5 for an explanation of the numbering system for ground-water sites.

Other ident ifier: Name given to coal-test hole or well by party responsible for drilling. MC, Muddy Creek Coal Drilling owner or operator: Company or Federal agency responsible for drilling.

Altitude of land surface: Given in feet above National Geodet ic Vertical Datum of 1929.

Depth to Star Point Sandstone: Given in feet to top of Star Point Sandstone except where noted; *. feet to top of upper Logs available: From party responsible for drilling: G, gamma; D, density; C, caliper; R, resist ivity; SP, Spontaneous Completion of hole: As shown; most coal-exploration drill holes are filled with cement after drilling, coring, and Remarks: Recorded on drillers' $\log$ or by U.S. Geological Survey or Coastal States Energy Co. representative.

Dashes (--), no data.

\begin{tabular}{|c|c|c|c|c|c|c|c|}
\hline Location & $\begin{array}{l}\text { Other identifier } \\
\text { (pl. 1) }\end{array}$ & amer or operator & $\begin{array}{l}\text { Year } \\
\text { completed }\end{array}$ & $\begin{array}{c}\text { Alt itude of } \\
\text { land surface } \\
\text { (feet) }\end{array}$ & $\begin{array}{l}\text { Depth } \\
\text { drilled } \\
\text { (feet) }\end{array}$ & $\begin{array}{l}\text { Depth to } \\
\text { Star Point } \\
\text { Sandstone } \\
\text { (feet) }\end{array}$ & $\begin{array}{l}\text { Logs } \\
\text { availlable }\end{array}$ \\
\hline$\frac{(D-20-5)}{32 a c}$ & $\begin{array}{l}M C-10-H M \\
M C-7-F P\end{array}$ & $\begin{array}{c}\text { U.S. Geological Survey } \\
\text { do. }\end{array}$ & $\begin{array}{l}1980 \\
1980\end{array}$ & $\begin{array}{l}8,152 \\
8,319\end{array}$ & $\begin{array}{l}1,180 \\
1,080\end{array}$ & $\begin{array}{l}1,112 \\
1,033\end{array}$ & $\begin{array}{l}C, D, G, R \\
C, D, G, R, S P\end{array}$ \\
\hline $\begin{array}{l}(0-21-4) 13 a b \\
23 a a \\
24 a b d-1\end{array}$ & $\begin{array}{l}M C-71-A \\
M C-75-A L \\
M C-17-A L\end{array}$ & $\begin{array}{l}\text { do. } \\
\text { do. } \\
\text { do. }\end{array}$ & $\begin{array}{l}1979 \\
1980 \\
1979\end{array}$ & $\begin{array}{l}8,380 \\
8,454 \\
8,317\end{array}$ & $\begin{array}{l}1,430 \\
1,520 \\
1,260\end{array}$ & $\begin{array}{l}1,343 \\
1,464 \\
1,209\end{array}$ & $\begin{array}{l}C, D, G, R \\
C, D, G, R \\
C, D, G, R, T\end{array}$ \\
\hline $24 c b c-1$ & $M C-18-A L$ & do. & 1979 & 8,271 & 1,222 & 1,189 & $C, D, G, R, T$ \\
\hline $25 b b b-1$ & US-81-4 & Coastal States Energy & 1981 & 8,380 & 1,300 & $\star 1,201$ & - \\
\hline $25 c c c-1$ & US $-81-3$ & do. & 1981 & 9,026 & 1,980 & $\star 1,732$ & -- \\
\hline $25 d c d-1$ & US -81-2 & do. & 1981 & 8,686 & 1,460 & $\star 1,333$ & - \\
\hline
\end{tabular}


Project, Smith, 1981; US, Coastal States Energy Co.; W-TP, U.S. Geological Survey, Blanchand and others, 1977.

Hiawatha coal seam.

potential; $T$, temperature.

logging, but some were converted to observation wells for recording water levels or logging temperatures.

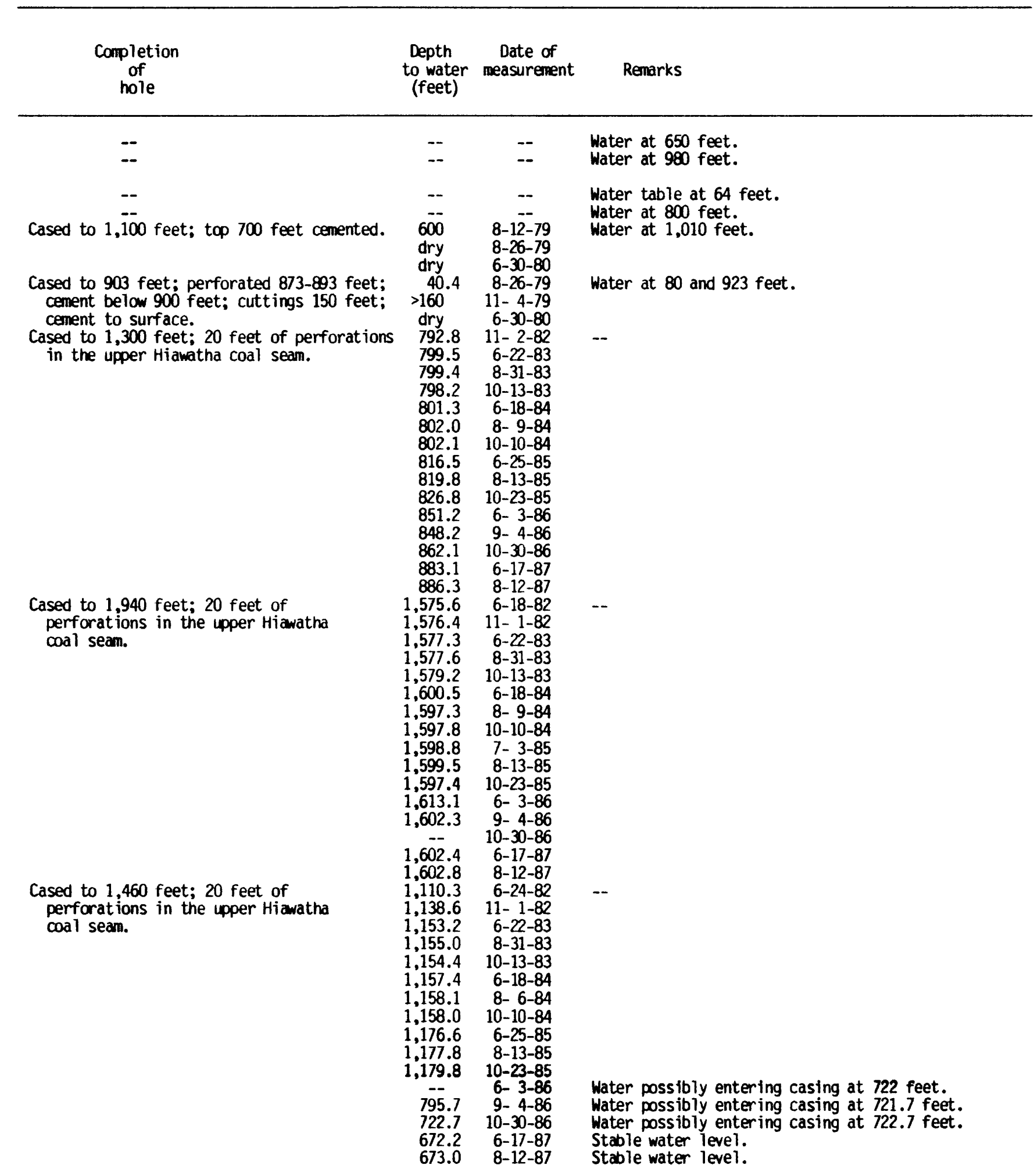


Table 8.--Geologic and hydrologic data from

\begin{tabular}{|c|c|c|c|c|c|c|c|}
\hline Location & $\begin{array}{l}\text { Other ident ifier } \\
\text { (pl. 1) }\end{array}$ & Omer or operator & $\begin{array}{l}\text { Year } \\
\text { completed }\end{array}$ & $\begin{array}{c}\text { Altitude of } \\
\text { land surface } \\
\text { (feet) }\end{array}$ & $\begin{array}{l}\text { Depth } \\
\text { drilled } \\
\text { (feet) }\end{array}$ & $\begin{array}{l}\text { Depth to } \\
\text { Star Point } \\
\text { Sandstone } \\
\text { (feet) }\end{array}$ & $\begin{array}{l}\text { Logs } \\
\text { available }\end{array}$ \\
\hline $\begin{array}{r}(D-21-4) 34 a b d-1 \\
36 c d a-1\end{array}$ & $\begin{array}{l}\text { MC-21-AL } \\
\text { US-80-2 }\end{array}$ & $\begin{array}{l}\text { U.S. Geological Survey } \\
\text { Coastal States Energy }\end{array}$ & $\begin{array}{l}1979 \\
1980\end{array}$ & $\begin{array}{l}8,438 \\
8,360\end{array}$ & $\begin{array}{r}1,443 \\
207\end{array}$ & $\begin{array}{r}1,416 \\
\star 930\end{array}$ & $C, D, G, R$ \\
\hline
\end{tabular}

$36 \mathrm{dac}-1 \quad$ US $-80-4$

do.

1980

8,397

242

*917 -- do.

$\begin{aligned} \text { (D-21 -5) 9ada-1 } & \text { W-TP-6-FP } \\ 14 a c c-1 & \text { W-TP-4-EW } \\ 16 a d d a-1 & \text { W-TP-5-EW } \\ 20 \text { bda-1 } & \text { W-TP-1-AL } \\ 23 \text { daa-1 } & \text { W-TP-3-EW } \\ 28 a b b-1 & \text { W-TP-2-EW } \\ 30 c b c-1 & \text { US-81-1 }\end{aligned}$

1977

8,378

1,095

992
U.S. Geological Survey

do.

do.

do.

do.

do.

Coastal States Energy

$\begin{array}{cc}\text { do. } & 1976 \\ \text { do. } & 1976 \\ \text { do. } & 1976 \\ \text { do. } & 1976 \\ \text { do. } & 1976 \\ \text { Coastal States Energy } & 1981\end{array}$

1976

8,350

1,000

8,465

1,080

8,350

975

8,300

1,020

8,650

1,030

8,480

1,193

1,300
8,490 


$\begin{array}{cc}\begin{array}{c}\text { Completion } \\ \text { of } \\ \text { hole }\end{array} & \begin{array}{c}\text { Depth } \\ \text { to water measurement } \\ \text { (feet) }\end{array}\end{array}$

Cased to 200 feet; 20 feet of perforations in the Castlegate Sandstone.

Cased to 240 feet; 40 feet of perforations in the Castlegate Sandstone.

Cased to 100 feet; perforated to 75 feet in the upper part of Blackhank Formation-lower part of Castlegate Sandstone.

Cased to 1,300 feet; 20 feet of perforations in the upper part of Hiawatha coal seam.

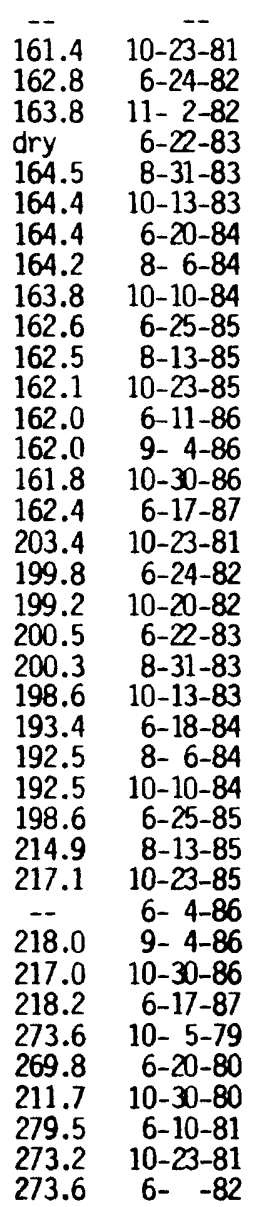

No appreciable water flowing into hole. --

Dry fran 11-1-82 through 6-17-87.

Fluid level 732 feet below land surface; from geophysical log taken 11-10-76.

Fluid level 82 feet below land surface; fram geophysical log taken 11-7-76.

Fluid level 95 feet below land surface; from geophysical log taken 11-7-76.

Fluid level 857 feet below land surface; from geophysical log taken 11-5-76.

Fluid level 680 feet below land surface; from geophysical log taken 10-1-76.

Fluid level 519 feet below land surface; from geophysical log taken 10-1-76. $--$
Water possibly entering casing at 514 feet. Water possibly entering casing at 514 feet. Water possibly entering casing at $\mathbf{4 1 2 . 7}$ feet. Water possibly entering casing at 413.1 feet. 
Table 8.--Geologic and hydrologic data from

\begin{tabular}{|c|c|c|c|c|c|c|c|}
\hline Location & $\begin{array}{l}\text { Other ident ifier } \\
\text { (pl. 1) }\end{array}$ & Omer or operator & $\begin{array}{l}\text { Year } \\
\text { completed }\end{array}$ & $\begin{array}{c}\text { Altitude of } \\
\text { land surface } \\
\text { (feet) }\end{array}$ & $\begin{array}{l}\text { Depth } \\
\text { drilled } \\
\text { (feet) }\end{array}$ & $\begin{array}{l}\text { Depth to } \\
\text { Star Point } \\
\text { Sandstone } \\
\text { (feet) }\end{array}$ & $\begin{array}{l}\operatorname{logs} \\
\text { available }\end{array}$ \\
\hline$(D-21-5) 31 a b c-1$ & US-77-7 & Coastal States Energy & 1977 & 8,493 & 1,220 & 1,148 & - \\
\hline$(D-22-4) 13 c a a-1$ & $M C-25-A L$ & U.S. Geological Survey & 1979 & 8,398 & 1,140 & 899 & $C, D, G, R$ \\
\hline \multirow{2}{*}{$\begin{array}{r}(D-22-5) 5 c a \\
5 c\end{array}$} & US-79-12 & Coastal States Energy & 1979 & 8,519 & 990 & $\star 877$ & - \\
\hline & US-79-13 & do. & 1979 & 8,525 & 1,010 & 958 & -- \\
\hline
\end{tabular}

$6 \mathrm{bb} \quad$ us-77-8

do.

1977

8,420

1,140

$932 \quad--$

$8 a c \quad$ US-79-10

$8 b b c-1 \quad$ US-79-9 do.

do.

1979
8,549

990

8,539

$-$
914 --

924 


$\begin{array}{cc}\begin{array}{c}\text { Completion } \\ \text { of } \\ \text { hole }\end{array} & \begin{array}{c}\text { Depth } \\ \text { to water measurement } \\ \text { (feet) }\end{array}\end{array}$

Cased to 138 feet; perforated $98-118$ feet.

Cased to 860 feet; 20 feet of perforations in the upper Hiawatha coal seam

Cased to 705 feet; 20 feet of perforations in sandstone in Blackhawk Formation; cement above and below perforations.

Cased to 160 feet: 110 feet of perforations in Castlegate Sandstone; cement above and below perforations.

Cased to 880 feet; 20 feet of perforations in the upper part of Hiawatha coal seam; cement above and below perforations.

Cased to 860 feet; 20 feet of perforations in the upper part of Hiawatha coal seam; cement above and below perforations.

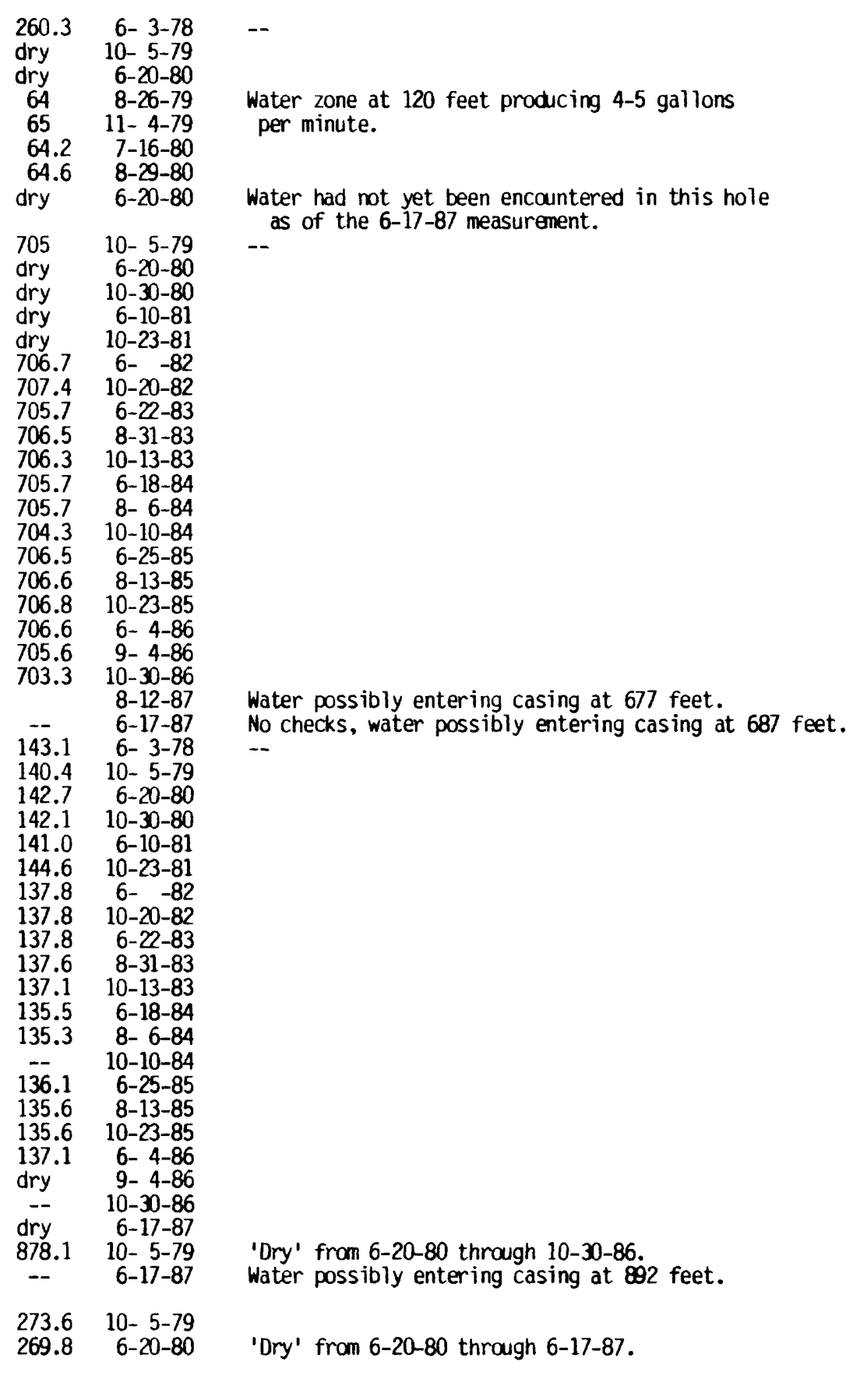


EFFECTS OF MINING IN THE QUITCHUPAH AND PINES

COAL-LEASE TRACTS AREA

\section{Potential Effects}

Subsidence of the land surface, as a result of underground mining, has the greatest potential to adversely affect the hydrology of the study area. Other possible effects of mining include the dewatering of the Blackhawk Formation and Star Point Sandstone changing natural drainage patterns, and alteration of both surface- and ground-water quality.

\section{Subsidence}

Subsidence in a coal-mining area may be caused by the collapse of overburden left insufficiently supported after the removal of underlying material. This flexure of the overburden creates tensile and compressional stresses within the upper part of the lithologic units. Strata that are curved convex (above coal pillars) undergo tensile stresses; whereas, strata that are curved concave (above mining cavities and near coal pillars or mine boundaries) undergo compressional stresses (Dunrud, 1976, p. 26). Many fractures caused by the lowering and/or collapse of strata above the mined coal can reach the land surface. Compression bulges, tension cracks, depressions, renewed fault scarps, and a general downwarping of the land surface are some of the surface expressions of subsidence.

According to Dunrud (1984, p. 171), many factors control the area, quantity, rate, and duration of subsidence in the western United States. The most important factors are the geology, hydrology, and topography of an area, geotechnical properties of the coal and rock above and below the coal, slope angle of the land surface, mining geometry and extraction ratio, and mining method.

\section{Ground-Water Occurrence and Quality}

Fractures in the overburden that result fram subsidence can serve as conduits directly to underlying strata or to the mine workings. The normal ground-water flow path can be changed by increasing the hydraulic conductivity between two different geohydrologic units. An example is the draining of a perched aquifer through fractures or through separations along bedding planes. Bentonitic shale and plastic flow in mudstone within perching layers could possibly slow or stop the downward movement of previously perched ground water.

Springs are an important source of water to both livestock and wildlife in the study area. Fractures caused by the collapse of overburden above mined areas could breach a perching layer that supplies springs, allowing groundwater to drain to underlying strata. Ground-water discharge to these springs could decrease or cease if the supplying perched zone is intersected.

The Blackhawk Formation and Star Point Sandstone could be expected to contribute a similar quantity of water to mining operations in the proposed coal-lease tracts as is encountered in active sections of the SUFCo mine. As indicated by Theis (1957), an aquifer out of equilibrium due to discharge by 
wells must be balanced either by an increase in recharge to the aquifer, by a decrease in the natural discharge from the aquifer, by a decrease of ground water in storage, or by a combination of the above. Water discharged by underground mines produces the same changes in a ground-water system as do wells. Dewatering of this aquifer could affect springs and seeps which may be located in the steep canyons where the lower part of the Blackhawk Formation and Star Point Sandstone are exposed.

The chemical quality of ground water in contact with mine workings may be altered. The addition of sediment and compounds such as gypsum $\left(\mathrm{CaSO}_{4} \cdot 2 \mathrm{H}_{2} \mathrm{O}\right)$ sprayed on the walls of the mine to control dust, can increase the dissolved-solids concentrations in ground water that contacts the mine workings.

\section{Surface-Water Flow and Quality}

Surface-water flow to natural drainages has the potential of being intercepted by subsidence fractures that extend to land surface and of being diverted to other surface-drainage areas or to the ground-water system. Surface-water catchment ponds may also be affected by the diversion of flow into fractures.

The size of the disturbed area caused by mining in the quitchupah and Pines coal-lease tracts will depend on the construction needed for new surface facilities. Construction and upkeep of access ways and facilities, if not properly controlled, can increase erosion and sediment yields. Unimproved roads accessing the study area can be easily rutted and gullied where they cross unoonsolidated material derived from the Price River and North Horn Formations.

The chemical quality of the water discharging from the mine will probably change after the mine is abandoned. Seiler and Baskin (1988, p. 37) documented increased mineralization of the ground water in two mines located in the Wasatch Plateau and the Book Cliffs. Dissolved-solids and sulfate concentrations increased greatly. Mine effluent entering a perennial stream will change the quality of streamflow downstream from the discharge point. The degree of change will depend on the quality and quantity of mine effluent added to the surface-water regime and the existing quality of the stream.

\section{Observed Effects}

\section{Subsidence}

Subsidence as a result of underground mining has occurred above the SUFCo mine. Tension cracks with apertures as large as $2.5 \mathrm{in}$. are visible at the surface.

The lithologic character of the overburden near the land surface can affect the degree of subsidence incurred. In the southern part of the Quitchupah and Pines study area, Dunrud (1984, p. 172) measured subsidence equal to about 45 percent of the thickness of mined coal where the overburden was composed of a massive sandstone. Above a weaker sequence of shale, mudstone, and lenticular sandstone, subsidence was as much as 90 percent of the thickness of mined coal. 
The area above the SUFCo mine, directly south of the Quitchupah coallease tract, is currently (1987) subsiding. Although it is not known exactly when subsidence first occurred in the area, it is believed to have coincided with the implementation of high-recovery mining methods in June 1976. Since that time, a subsidence-monitoring program has been in effect. The findings are compiled once a year and sent to the Utah Division of Oil, Gas, and Mining. A maximum subsidence of approximately $8 \mathrm{ft}$ was documented in 1977 (Southern Utah Fuel Co., 1978) above a mined area south of East Spring. As of $1986,8 \mathrm{ft}$ is still the maximum subsidence recorded in the SUFCo mine area (fig. 19).

New subsidence is occurring almost immediately above areas being mined by longwall methods. Area 6 (fig. 19) was scheduled to be mined in 1985 and 1986. Prior to mining, subsidence was not recorded in this area. Surface elevation changes measured from 1985 to October 1986, above part of the mined area, indicate a maximum subsidence of $2 \mathrm{ft}$. This new subsidence area is a direct response to the longwall-mining system used. Area 8 is also an active subsidence area that is currently (1987) being mined. Area 3 has not yet stabilized, and subsidence continued in 1986, although mining had ceased in 1983 (Dimick, 1987, p. 2).

Tension cracks resulting from subsidence are visible in unconsolidated material at the land surface (fig. 20) and in the underlying Castlegate Sandstone (fig. 2l). A set of cracks in the alluvium near Duncan Draw extend about $250 \mathrm{ft}$ and trend $\mathrm{N} 40^{\circ} \mathrm{E}$ to $\mathrm{N} 26^{\circ} \mathrm{E}$. The fissures vary in width from less than $0.1 \mathrm{ft}$ to 1 -foot diameter holes. In some areas, the fractured Castlegate Sandstone is exposed beneath as much as $3 \mathrm{ft}$ of alluvium where water piping into the cracks in bedrock has removed the overlying alluvium. The majority of tension cracks mapped by SUFCo mine personnel in subsidence area 1 are oriented parallel to subsidence contours (fig. 22). The widening of some natural fractures that trend northwest also indicates the effects of subsidence-related stress in the rocks.

\section{Ground-Water Occurrence and Quality}

Subsidence probably is the cause of a substantial change in water-level at the end of 1986 in a monitoring well completed in a sandstone layer of the Blackhawk Formation (fig. 23). This well is above an area that was longwall mined during 1986 and 1987. Subsidence may have caused the casing to break allowing water from a perched zone to flow into the well resulting in a $\mathrm{r}$ ise in water-level. The casing in wells (D-21-4)25dcd-1 and (D-21-5) 30cbc-1 also may have been breached above the perforations causing perched ground water to enter these wells (fig. 18).

The upper Hiawatha coal bed has been mined beneath two springs in the area, East Spring and (D-22-5)7aca-S1. East Spring is at the base of the Castlegate Sandstone at the southern end of subsidence area 4 (fig. 19). Spring discharge is measured and chemical analyses are performed three times a year by Coastal States Energy Company personnel to determine any changes in discharge or water quality. Subsidence has been documented at area 4 and at area 1, to the south of East Spring, but no major changes in flow rate or chemical composition were detected in East Spring from 1985 to 1986. As of August 5, 1987, subsidence effects had not been noted in East Spring. 


\section{EXPLANATION}

LAND SUBSIDENCE, IN FEET

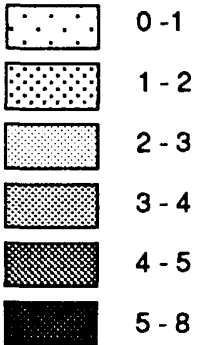

$0-1$

1 - 2

$2-3$

3- 4

$4-5$

$5-8$

$38^{\circ} 5730^{\prime \prime}-$

APPROXIMATE BOUNDARY BETWEEN AREAS WITH

DIFFERENT SUBSIDENCE
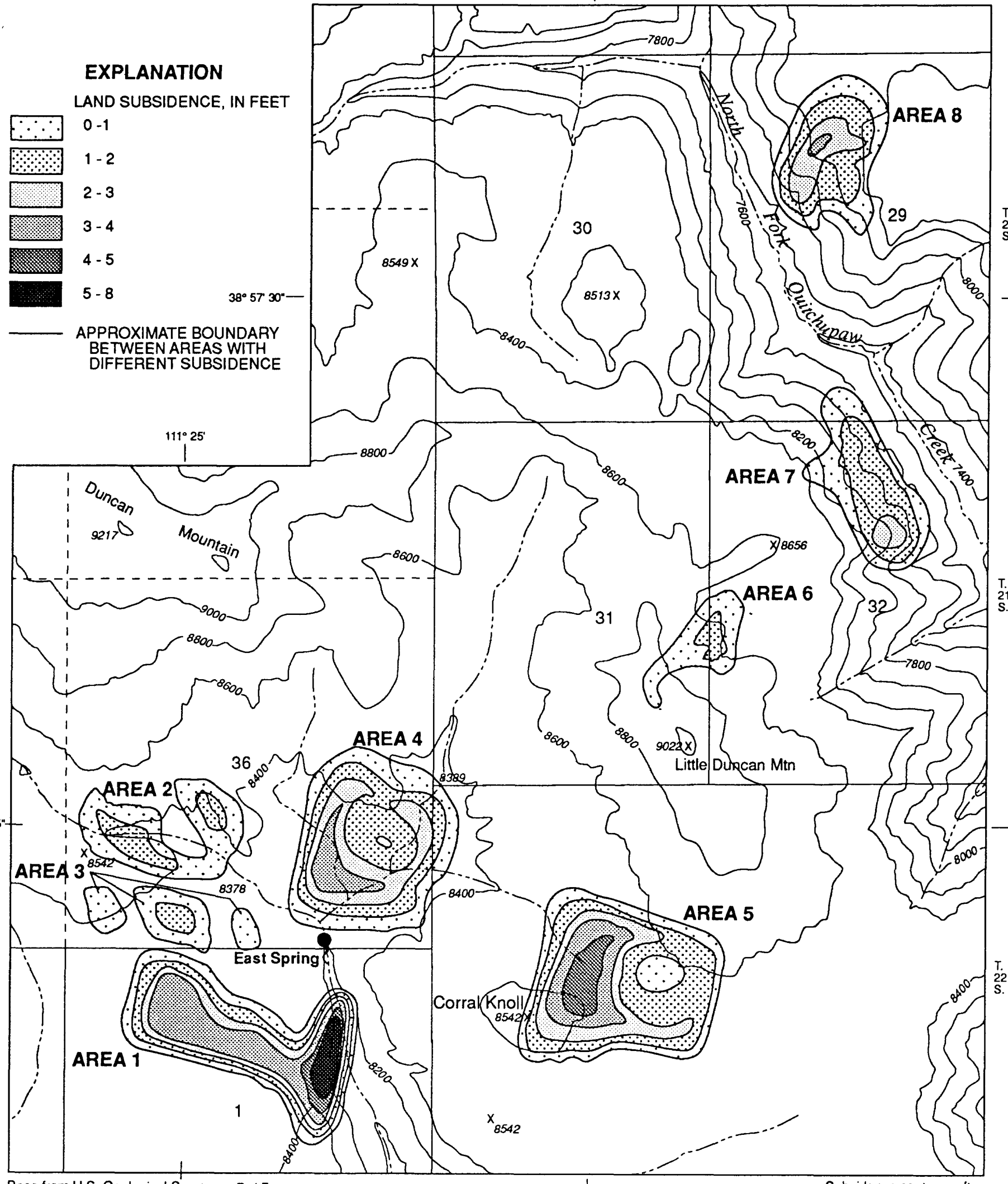

Base from U.S. Geological Survey R. $4 \mathrm{E}$ Acord Lakes, 1:24,000, 1968

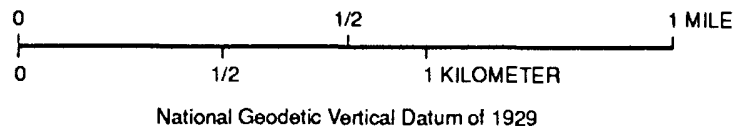

Figure 19.-- Extent of land subsidence in the southwestern part of the study area in 1986. 


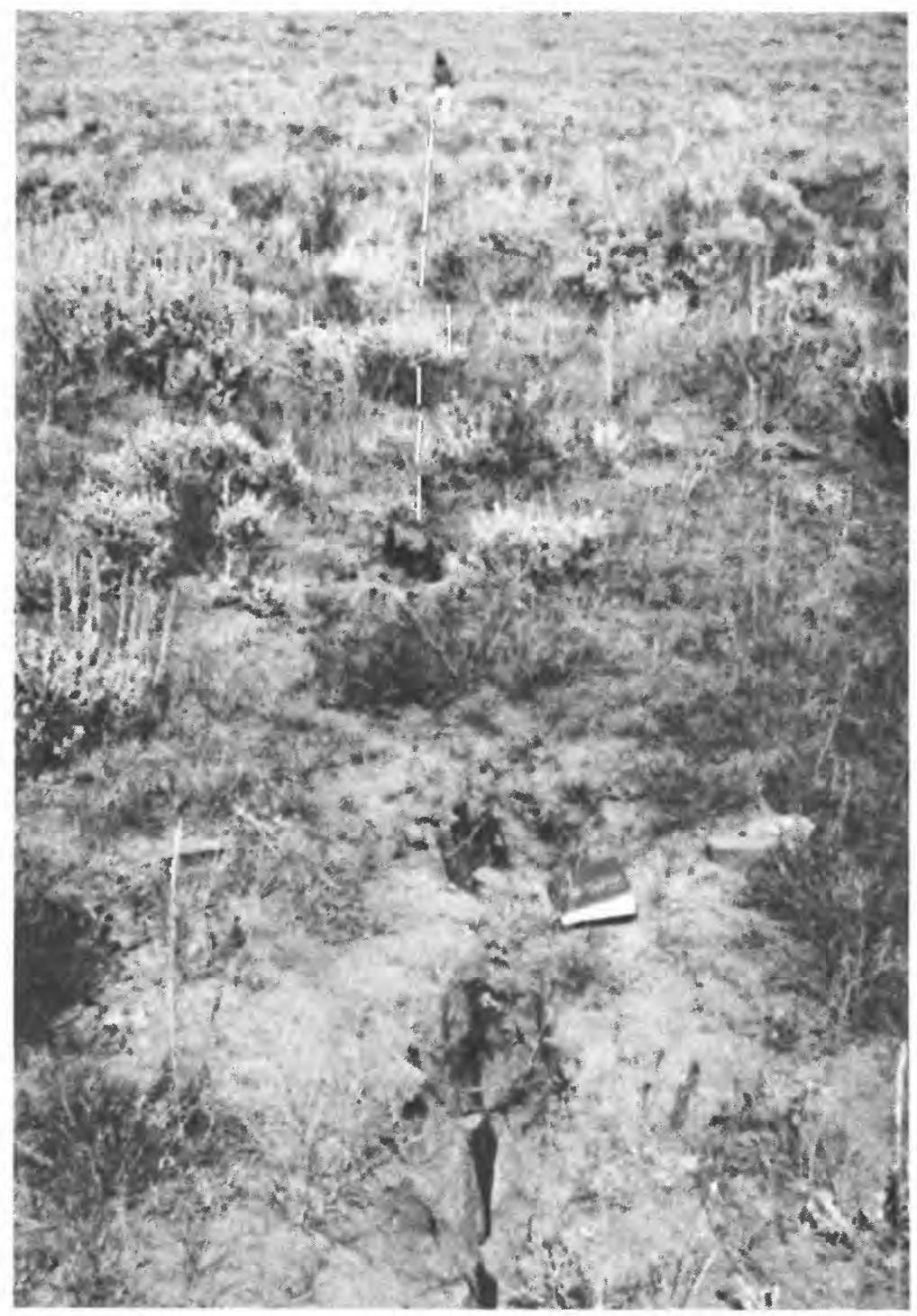

Figure 20.--Tension crack in alluvium near Duncan Draw. The crack extends south, toward the hydrologist about 250 feet. 


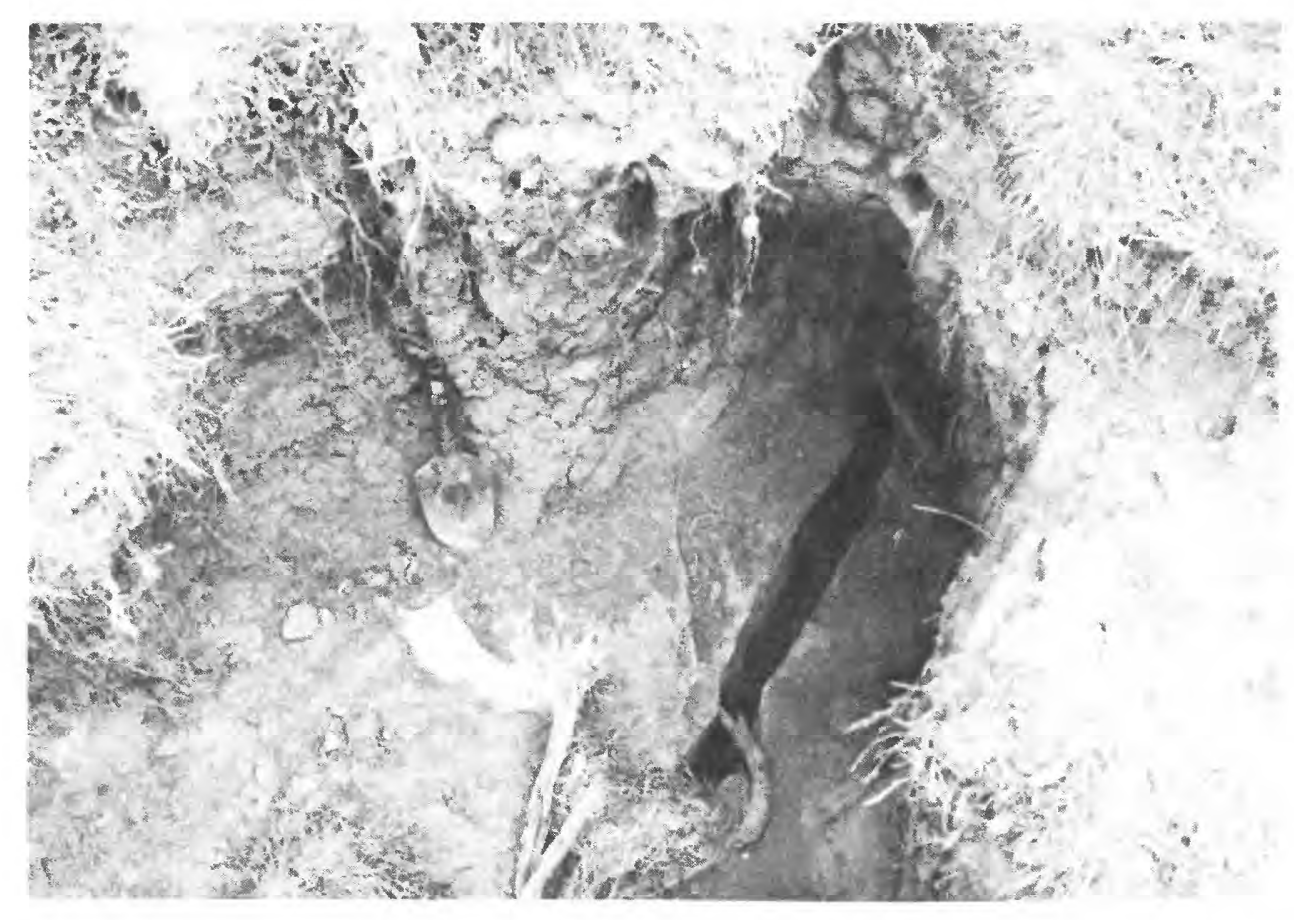

Figure 21.--Tension crack about 2.5 inches wide in the Castlegate Sandstone near Duncan Draw. Alluvium above sandstone has been removed by piping.

Spring (D-22-5)7aca-S1 (pl. 1) discharges from near the top of the Castlegate Sandstone above older mine workings where large coal pillars were left to support the overburden. Subsidence has not been measured in the area around this spring, and pre-mining water quality and quantity data are not available to determine if any changes have occurred.

Some faults that are intersected by the SUFCo mine are producing water, but most water production stops shortly after exposure by mining. According to Wesley Sorenson, SUFCo's chief engineer, (oral commun., August 24, 1987), the area of the mine just north of Duncan Mountain produced increasing quantities of water as it was extended by mining to the west. This area is crossed by many faults that may have contributed water, which increased in quantity as successive faults were intersected by mining.

\section{Surface-Water Flow and Quality}

Tension cracks, originating underground at the SUFCo mine, divert surface runoff that normally flows in established drainages, to the groundwater system. The authors have observed fractures oriented perpendicular to the surface-water flow path which probably intercept runoff and cause piping through the alluvium into the Castlegate Sandstone. Since these cracks originate near the base of the Blackhawk Formation, it is probable that the Blackhawk Formation is being recharged by this diverted surface-water flow. 


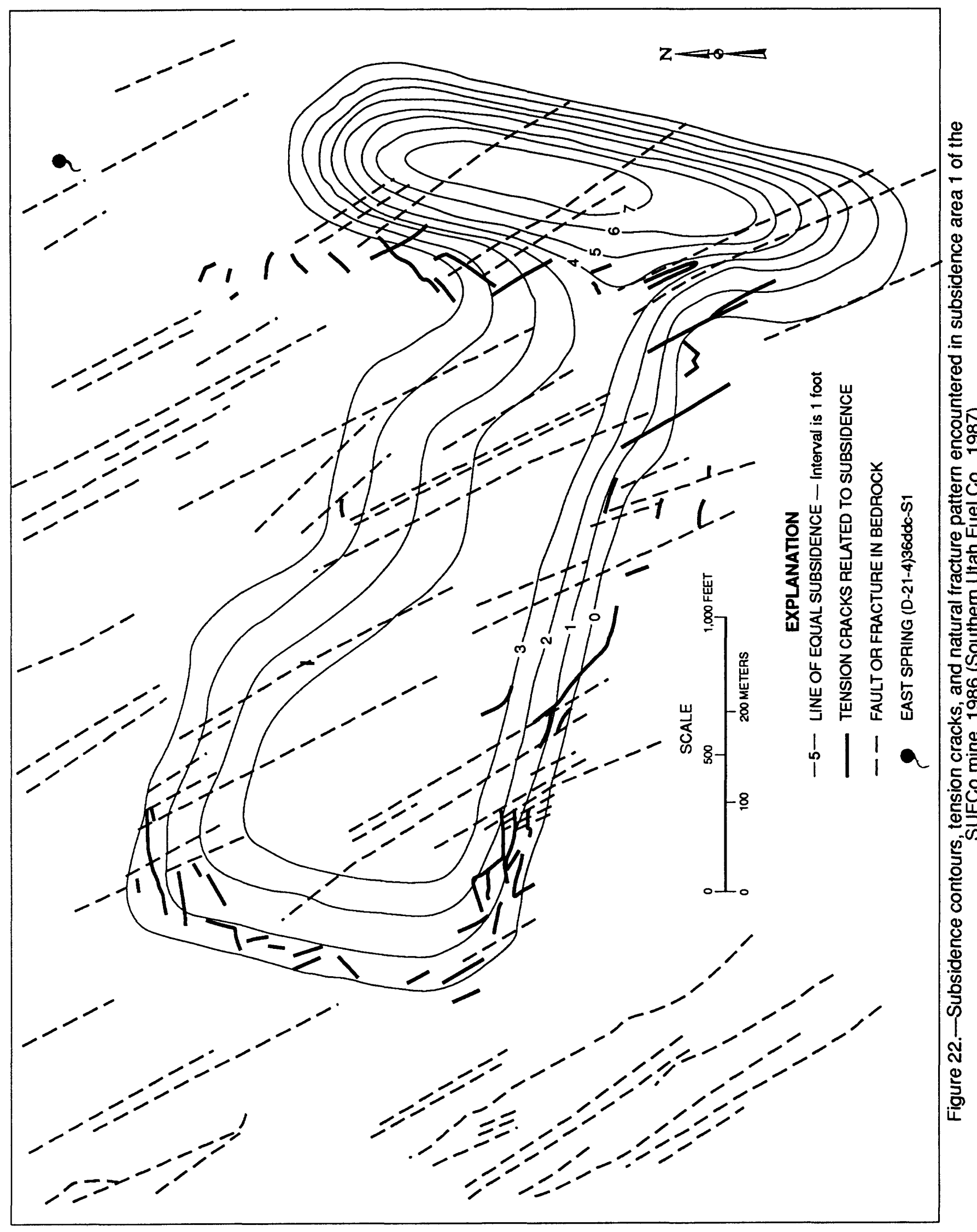




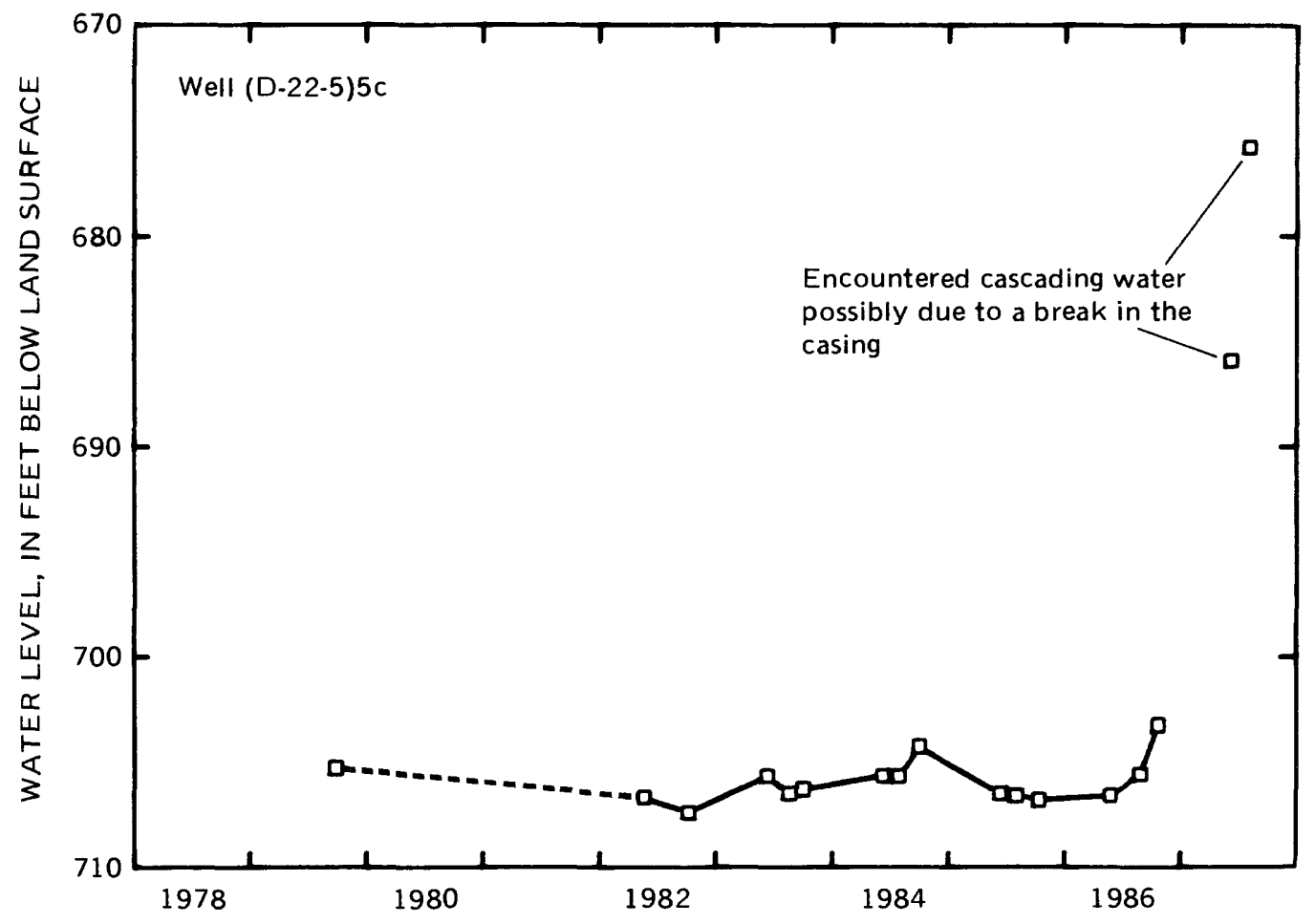

Figure 23.--Changes in the water level in monitoring well (D-22-5)5c.

Water entering the SUFCo mine through faults, open bolt holes, recently mined faces, and as downward leakage through overlying sandstone is pumped or drained into nearby surface-water drainages. Before September 1982, ground water collected in the mine was discharged into East Spring Canyon (GN-28, pl. 1). After September 1982, the ground water was discharged into the North Fork Quitchupah Creek (GN-24, pl. 1).

Discharge from mining can substantially increase the base flow of the stream to which it is discharged. Seasonal records for site SW-28 on Quitchupah Creek (09331850) (Price and Plantz, 1986) indicate that the average discharge rate was $200 \mathrm{gal} / \mathrm{min}$ in 1978 and $520 \mathrm{gal} / \mathrm{min}$ in 1982 (Hydrometrics, 1983, p. 17). In 1982, the water discharged from the mine into East Spring Canyon made up more than one half of the base flow of quitchupah Creek. The increase in mine discharge was probably the result of the increase in the area mined.

The Quitchupah portal (GW-24) drains the SUFCo mine by gravity flow and has discharged continuously since installation in 1982. During a seepage investigation on September 10, 1987, the flow of North Fork Quitchupah Creek directly upstream from the portal was $226 \mathrm{gal} / \mathrm{min}$; flow downstream from the portal was $687 \mathrm{gal} / \mathrm{min}$. The portal outflow contributed $461 \mathrm{gal} / \mathrm{min}$. SUFCo mine personnel measure the portal discharge on a biweekly basis and reported an average discharge of about 1,050 gal/min (Wesley Sorenson, SUFCo mine chief engineer, oral commun., August 24, 1987). The estimated total discharge from the mine during 1986 was about 1,700 acre-ft. 
The composition of ground water discharged from the SUFCo mine at the Quitchupah portal is different than that of ground water collected from fractures in the roof of the mine. Dissolved-solids concentration are about twice as large and sulfate concentrations are about five times larger in water discharging from the mine, yet still meet Utah's primary drinking water standards (Utah Bureau of Drinking Water/Sanitation, 1986).

\section{Predicted Effects}

The observed effects of mining at the SUFCo mine are considered indicative of the changes that can be expected in the quitchupah and Pines coal-lease tracts. Namely, long-wall mining of coal in the Quitchupah and Pines coal-lease tracts is likely to change (1) the chemical composition of ground water that flows into the mined area; (2) the quantity and quality of flow in nearby streams to which mine water is discharged; (3) the direction and quantity of surface-water runoff above underground mining areas because of diversion of runoff into tension cracks; (4) the quantity of water recharging aquifers that overlie a mined area; and (5) the quantity of ground water moving vertically between aquifer layers. If present mining practices remain unchanged, it is unlikely that the hydrologic effects of mining will substantially disrupt existing uses of water in the coal-lease tracts. However, hydrologic data for the area are limited, and many aspects of this hydrologic system are still unknown.

\section{ADDITIONAL STUDIES NEEDED}

Additional studies are needed to gain a better understanding of the hydrologic effects of underground coal mining in the study area. Observation wells completed in a single water-bearing zone, out of the range of subsidence, would help define baseline chemical composition of the ground water, aquifer characteristics, potentiometric surfaces, directions of groundwater movement, and hydraulic connection between water-bearing zones. Monitoring water levels in the observation wells before, during, and after mining could show the effects of mining on the hydrologic system.

Discharge measurements and water-quality analyses of selected springs at regular intervals prior to and during the mining of an area could be used to detect abnormal changes in flow and quality after mining has commenced. Water levels in observation wells could be monitored in conjunction with springdischarge measurements in order to detect large changes in recharge that may effect the hydrographs. Any changes in the chemical composition of water from springs and wells could be useful in determining how subsidence changes flow between aquifers and between aquifers and streams. Gaging stations on streams that drain potential coal-lease areas would provide baseline information on variability in stream discharge, water quality, and suspended-sediment concentrations. Data from continued monitoring at these stations during and after mining could be compared to baseline data to determine trends associated with mining. 


\section{SUMMARY AND CONCLUSIONS}

The Quitchupah and Pines coal-lease tracts, located in the Wasatch Plateau coal field of central Utah, include a total of about 30 square miles. Hydrologic data were collected from these tracts and the surrounding area in order to describe the hydrology and determine the potential effects of underground coal mining on the hydrologic system. The upper Hiawatha coal seam of the Cretaceous Blackhawk Formation currently is (1987) being mined in an area adjacent to the Quitchupah coal-lease tract by the Southern Utah Fuel company.

Streams in the area drain to either Quitchupah or Muddy Creeks. Peak streamflow generally occurs in the spring due to snowmelt, although large flows can occur in the late sumer and fall in response to thunderstorms.

The specific conductance of surface water in the study area decreases as streamflow increases because of dilution from runoff. Prior to the water's flowing across the lower part of the Blackhawk Formation, calcium, magnesium, and bicarbonate plus carbonate are the predominant ions. Surface water that has flowed across the Blackhawk Formation, Star Point Sandstone, and part of the Mancos Shale shows an increase in sulfate concentration.

Suspended-sediment concentrations are generally related to stream discharge. Although the largest concentration was measured on North Fork Quitchupah Creek during spring runoff, the largest suspended-sediment concentrations are usually the result of runoff from intense thunderstorms.

Parts of the Blackhawk Formation and the Star Point Sandstone are saturated in most of the study area. Water levels in several observation wells completed in the upper Hiawatha coal seam of the Blackhawk Formation are artesian (above the top of the perforated zone). The Blackhawk Formation and Star Point Sandstone are not saturated near the edge of the plateau, near canyons, and near the SUFCo mine where they are being dewatered.

Recharge to the saturated zones is principally by snowmelt seeping into outcrops. The annual recharge to the Castlegate Sandstone and the Price River Formation is estimated to be only about 1.2 percent of the annual normal precipitation. Water movement is controlled mainly by fractures, dip of the beds, and hydraulic conductivity of the materials. Most springs inventoried discharge near formation contacts and all of the springs found discharging from the Castlegate Sandstone were located on the east side of canyons, downdip from recharge areas.

Concentrations of dissolved solids in ground water sampled from springs and mines in the area ranged from $61 \mathrm{mg} / \mathrm{L}$ for water issuing near the top of the Castlegate Sandstone to $1,080 \mathrm{mg} / \mathrm{L}$ for water issuing from alluvium near the base of the North Horn Formation. Solubility indices indicate that water from most formations in the study area is undersaturated with respect to gypsum, anhydrite, and magnesite. The Flagstaff Limestone, North Horn Formation, and Price River Formation are supersaturated with respect to calcite and dolomite.

Water discharged from the SUFCo mine portal shows a greater concentration of sulfate than ground water discharging from the mine roof. 
Tritium concentrations indicate that water discharging from a fault in the SUFCo mine must have entered the ground-water system at least 70 years ago while some of the water discharging from a spring at the base of the Castlegate Sandstone must have been recharged to the ground-water system sometime after 1952.

Observed effects of underground coal mining at the nearby Southern Utah Fuel Company mine are considered indicative of the changes that can be expected in the Quitchupah and Pines coal-lease tracts. Subsidence above the mined area could cause dewatering of the Blackhawk Formation and Star Point Sandstone, changes in the natural drainage patterns, and alteration of both surface- and ground-water quality. Additional studies are needed to gain a better understanding of the hydrologic effects of underground mining in the quitchupah and Pines coal-lease tracts.

\section{REFERENCES CITED}

Blanchard, L.F., Ellis, E.G., and Roberts, J.V., 1977, Lithologic and geophysical logs of holes drilled in the Wasatch Plateau known recoverable coal resource area, Carbon, Emery, and Sevier counties, Utah: U.S. Geological Survey Open-File Report 77-133, 324 p.

Christensen, R.C., Johnson, E.B., and Plantz, G.G., 1986, Manual for estimating selected streamflow characteristics of natural flow streams in the Colorado River Basin in Utah: U.S. Geological Survey Water-Resources Investigations Report 85-4297, 39 p.

Davis, F.D., and Doelling, H.H., 1977, Coal drilling at Trail Mountain, North Horn Mountain, and Johns Peak areas, Wasatch Plateau, Utah: Utah Geological and Mineral Survey Bulletin 112, 90 p.

Danielson, T.W., ReMillard, M.D., and Fuller, R.H., 1981, Hydrology of the coal-resource areas in the upper drainages of Huntington and cottonwood Creeks, central Utah: U.S. Geological Survey Water-Resources Investigations Open-File Report 81-539, 85 p.

Danielson, T.W., and Sylla, D.A., 1983, Hydrology of coal-resource areas in the southern Wasatch Plateau, central Utah: U.S. Geological Survey Water-Resources Investigations Report 82-4009, 66 p.

Dimick, D., 1987, 1986 subsidence report, Southern Utah Fuel Company, Mine No. 1: Southern Utah Fuel Company, Salina, Utah, on file in offices of Utah Division of Oil, Gas, and Mining, Salt Lake City, Utah, 3 p., 3 pl.

Doelling, H.H., 1972, Central Utah coal fields: Sevier-Sanpete, Wasatch Plateau, Book Cliffs and Emery: Utah Geological and Mineralogical Survey Monograph Series No. 3, 580 p.

Dunrud, C.R., 1976, Some engineering geologic factors controlling coal mine subsidence in Utah and Colorado: U.S. Geological Survey Professional Paper 969, 39 p. 
- -1984, Coal mine subsidence--Western United States in Man-induced land subsidence: Reviews in Engineering Geology v. VI, Geological Society of America, Boulder, Colo., p. 151-194.

Farnsworth, R.K., Thompson, E.S., and Peck, E.L., 1982, Evaporation atlas for the contiguous 48 United States: National Oceanic and Atmospheric Administration Technical Report NWS 33.

Frickel, F.K., Shown, L.M., and Patton, P.C., 1975, An evaluation of hillslope and channel erosion related to oil-shale development in the Piceance Basin, northwestern Colorado: Colorado Water Resources Circular $30,37 \mathrm{p}$.

Hayes, P.T., and Sanchez, J.D., 1979, Geologic map and coal resources of the Emery West Quadrangle, Emery and Sevier counties, Utah: U.S. Geological Survey Coal Investigations Map C-82.

Hem, J.D., 1985, Study and interpretation of the chemical characteristics of natural water (3d ed.): U.S. Geological Survey Water-Supply Paper 2254, $263 \mathrm{p}$.

Hydrometrics, 1983, Hydrological assessment and monitoring report, Southern Utah Fuel Company, Mine No. 1, Salina, Utah: Helena, on file in offices of Utah Division of Oil, Gas, and Mining, Salt Lake City, Utah, 63 p.

Johnson, J.L., 1978, Stratigraphy of the coal-bearing Blackhawk Formation on North Horn Mountain, Wasatch Plateau, Utah: Utah Geology, v. 5, no. 1, p. 57-77.

Lines, G.C., 1985, The ground-water system and possible effects of underground coal mining in the Trail Mountain area, central Utah: U.S. Geological Survey Water-Supply Paper 2259, $32 \mathrm{p}$.

Lines, G.C., and Morrissey, D.J., 1983, Hydrology of the Ferron Sandstone aquifer and effects of proposed surface-coal mining in Castle Valley, Utah: U.S. Geological Survey Water-Supply Paper 2195, 40 p.

Miller, J.F., Frederick, R.H., and Tracey, R.J., 1973, Precipitationfrequency atlas of the western United States, Volume VI-Utah: National Oceanic and Atmospheric Administration Atlas 2, 67 p.

National Oceanic and Atmospheric Administration, 1979-86, Climatological data, Utah: Asheville, N.C., v. 81-88, no. 1-13.

Parkhurst, D.L., Thorstenson, D.C., and Plumner, L.N., 1980, PHREEQE--A computer program for geochemical calculations: U.S. Geological Survey Water-Resources Investigations Report 80-96, 193 p.

Price, D., and Plantz, G.G., 1986, Hydrologic monitoring of selected streams in coal fields of central and southern Utah-surmary of data collected, August 1978-September 1984: U.S. Geological Survey Water-Resources Investigations Report 86-4017, 102 p. 
Rapin, D.L., 1977, Soil resource inventory, Ferron-Price planning unit, Manti-Ia Sal National Forest: U.S. Department of Agriculture, Forest Service Soils Report, 74 p.

Sanchez, J.D., and Hayes, P.T., 1979, Geologic map and coal resources of the Flagstaff Peak quadrangle, Emery, Sanpete, and Sevier counties, Utah: U.S. Geological Survey Coal Investigations Map C-83.

Seiler, R.L., and Baskin, R.L., 1988, Hydrology of Alkali Creek and Castle Valley Ridge coal-lease tracts, central Utah, and potential effects of coal mining: U.S. Geological Survey Water-Resources Investigations Report 87-4186, 53 p.

Smith, A.D., 1981, Muddy Creek coal drilling project, Wasatch Plateau, Utah: Utah Geological and Mineral Survey Special Studies 55, 57 p.

Southern Utah Fuel Company, 1978, 1977 subsidence report, Southern Utah Fuel Company, Mine No. 1: Salina, Utah, on file in offices of Utah Division of Oil, Gas, and Mining, Salt Lake City, Utah.

- - 1987, 1986 subsidence report, Southern Utah Fuel Company, Mine No. 1: Salina, Utah, on file in offices of Utah Division of Oil, Gas, and Mining, Salt Lake City, Utah.

Spieker, E.M., 1931, The Wasatch Plateau coal field, Utah: U.S. Geological Survey Bulletin 819, p. 210 .

Stiff, H.A., 1951, The interpretation of chemical water analysis by means of patterns: Journal of Petroleum Techniques, Technical Note 84, p. 15-17.

Thatcher, L.L., Janzer, V.J., and Edwards, K.W., 1977, Methods for the determination of radioactive substances in water and fluvial sediments: U.S. Geological Survey Techniques of Water-Resources Investigations, Book 5, Chapter A5, 95 p.

Theis, C.V., 1957, The source of water derived from wells, essential factors controlling the response of an aquifer to development: U.S. Geological Survey Ground Water Notes $34,16 \mathrm{p}$. (published in 1940 by American Society of Civil Engineering in Civil Engineering, p. 277-280).

Thomas, B.E., and Lindskov, K.L., 1983, Methods for estimating peak discharge and flood boundaries of streams in Utah: U.S. Geological Survey WaterResources Investigations Report 83-4129, 77 p.

U.S. Department of Agriculture, 1973, Estimating sediment yield rates for the State of Utah: Western United States Water-Plan Map, scale 1:500,000.

U.S. Environmental Protection Agency, 1986, Maximum contaminant levels (subpart B of part 141, National interim primary drinking-water regulations): U.S. Code of Federal Regulations, Title 40, Parts 100 to 149, revised as of July 1, 1986, p. 524-528. 
U.S. Weather Bureau, 1963, Normal annual precipitation and normal MaySeptember precipitation $(1931-60)$ for the State of Utah: Map of Utah, scale 1:500,000.

Utah Bureau of Drinking Water/Sanitation, 1986, State of Utah public drinking water regulations: Part I, 5th revision adopted February 1, 1986, p. 3.1.

Waddell, K.M., Contratto, P.K., Sumsion, C.T., and Butler, J.R., 1981, Hydrologic reconnaissance of the Wasatch Plateau-Book Cliffs coal-fields area, Utah: U.S. Geological Survey Water-Supply Paper 2068, 45 p., 9 pl.

Waddell, K.M., Dodge, J.E., Darby, D.W., and Theobald, S.M., 1986, Hydrology of the Price River Basin, Utah, with emphasis on selected coal-field areas: U.S. Geological Survey Water-Supply Paper 2246, 51 p.

Whaley, B.L., and Lytton, L.K., 1979, Summary of snow survey measurements for Utah, 1924-79: U.S. Department of Agriculture, Soil Conservation Service, $321 \mathrm{p}$.

Williams, P.L., and Hạckman, R.J., 1971, Geology, structure, and uranium deposits of the Salina quadrangle, Utah: U.S. Geological Survey Miscellaneous Geologic Investigations Map I-591, 2 sheets, 1:250,000. 